US Army Corps of Engineers ${ }_{\circledast}$

Engineer Research and

Development Center

Environmental Security Technology Certification Program (ESTCP)

\title{
Pulverized Paper as a Soil Carbon Source for Degraded Training Lands
}

Final Report

Ryan R. Busby, H. Allen Torbert, and Stephen A. Prior

September 2019

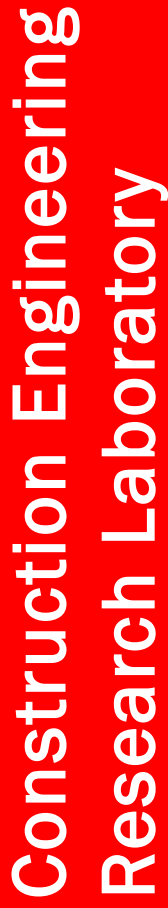

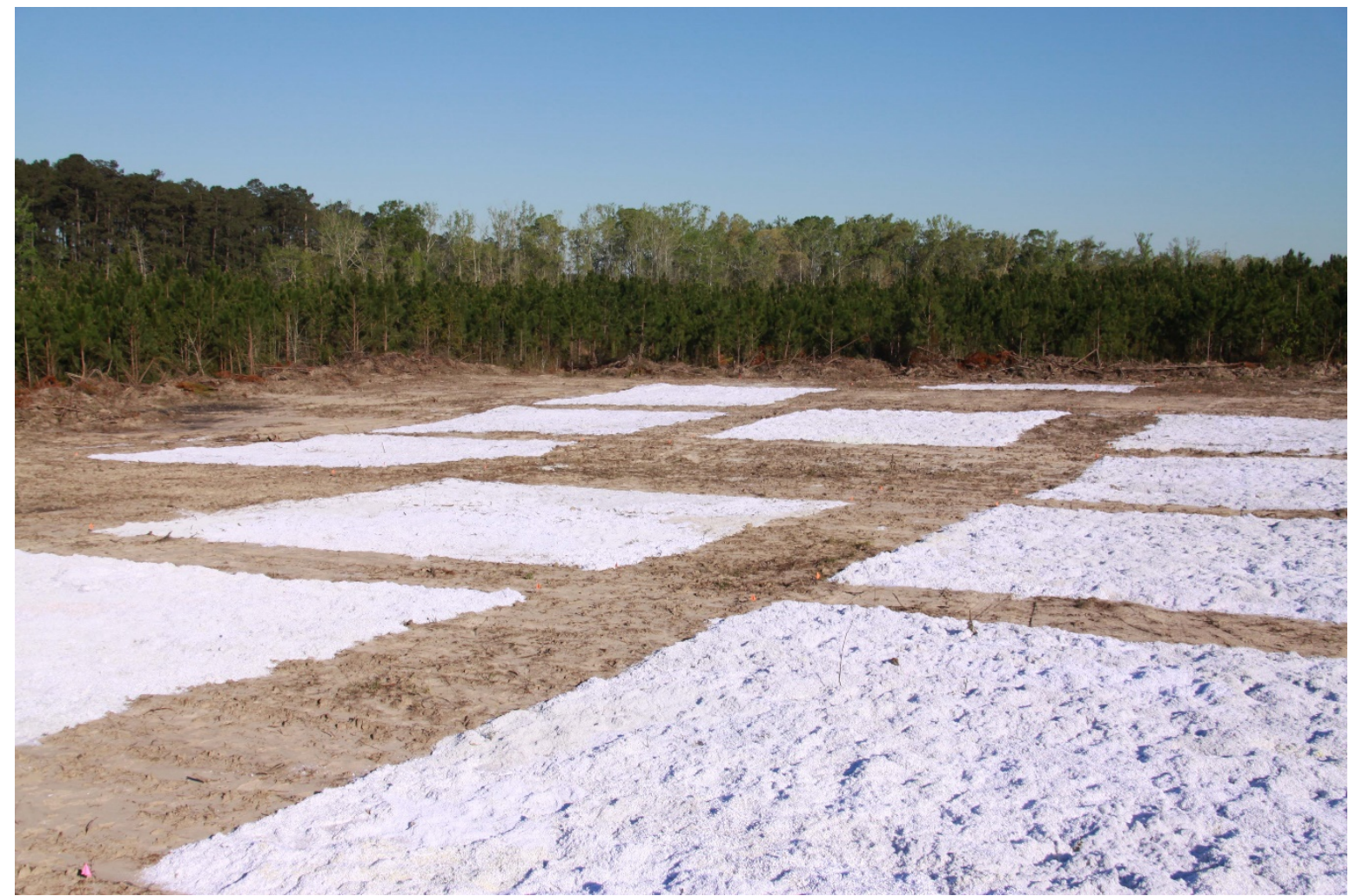


The U.S. Army Engineer Research and Development Center (ERDC) solves the nation's toughest engineering and environmental challenges. ERDC develops innovative solutions in civil and military engineering, geospatial sciences, water resources, and environmental sciences for the Army, the Department of Defense, civilian agencies, and our nation's public good. Find out more at www.erdc.usace.army.mil.

To search for other technical reports published by ERDC, visit the ERDC online library at http://acwc.sdp.sirsi.net/client/default. 


\section{Pulverized Paper as a Soil Carbon Source for Degraded Training Lands}

Final Report

Ryan R. Busby

Construction Engineering Research Laboratory

U.S. Army Engineer Research and Development Center

2902 Newmark Drive

Champaign, IL 61822

H. Allen Torbert and Stephen A. Prior

USDA Agricultural Research Service

411 S. Donahue Drive

Auburn, AL 36832

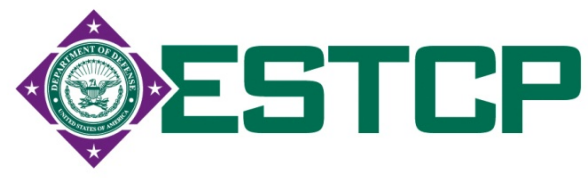

Final report

Approved for public release; distribution is unlimited.

Prepared for Environmental Security Technology Certification Program 4800 Mark Center Drive, Alexandria, VA 22350

Under Project Number RC-201416, "Pulverized Paper as a Soil Carbon Source for Degraded Training Lands" 


\section{Abstract}

A demonstration and validation project for the utilization of pulverized classified paper waste as a soil amendment to improve de-graded training lands was investigated. Military training lands are often lacking in soil organic matter, which improves water infiltration along with nutrient and moisture retention. When these lands are disturbed, nutrient availability favors weed establishment making restoration difficult. High carbon (C) wastes could help but are unfeasible because of cost and availability. Federal regulations require that classified paper be pulverized to very small fragments, negating recyclability. This material is currently landfilled, so reuse of this waste material is advantageous to training land management and also supports NetZero Waste initiatives.

Based on the results of this project, pulverized paper can be safely applied to degraded training lands to improve establishment of desirable vegetation without any discernable negative consequences. When combining cost savings associated with landfill disposal of the paper with savings from greater land rehabilitation success, an estimated $\$ 300$ per ton of diverted paper is realized. At the recommended application rate, this results in a cost savings of approximately $\$ 4,700$ per acre. At the installation level, this equates to an estimated annual costs savings of $\$ 20,000$ with 70 tons of paper diverted.

DISCLAIMER: The contents of this report are not to be used for advertising, publication, or promotional purposes. Citation of trade names does not constitute an official endorsement or approval of the use of such commercial products. All product names and trademarks cited are the property of their respective owners. The findings of this report are not to be construed as an official Department of the Army position unless so designated by other authorized documents. 


\section{List of Acronyms}

$\begin{array}{ll}\text { AC } & \text { Acres } \\ \text { ANOVA } & \text { Analysis of Variance } \\ \text { AR } & \text { Army Regulation } \\ \text { C } & \text { Carbon } \\ \text { CEC } & \text { Cation Exchange Capacity } \\ \text { COMSEC } & \text { Communication Security } \\ \text { DoD } & \text { Department of Defense } \\ \text { EO } & \text { Executive Order } \\ \text { FY } & \text { Fiscal Year } \\ \text { HA } & \text { Hectares } \\ \text { KPH } & \text { Kilometers Per Hour } \\ \text { MPH } & \text { Miles Per Hour } \\ \text { MSW } & \text { Municipal Solid Waste } \\ \text { N } & \text { Nitrogen } \\ \text { PET } & \text { Polyethylene Terephthalate } \\ \text { PLS } & \text { Pure Live Seed }\end{array}$




\section{Preface}

This study was conducted for the Environmental Security Technology Certification Program under Project Number RC-201416, "Pulverized Paper as a Soil Carbon Source for Degraded Training Lands." The technical monitor was Kurt Preston, Resource Conservation Program Manager.

The work was performed by the Ecological Processes Branch of the Installations Division (CEERD-CNN), U.S. Army Engineer Research and Development Center, Construction Engineering Research Laboratory (ERDCCERL). At the time of publication, Dr. Chris C. Rewerts was Chief, CEERD-CNN; Michelle J. Hanson was Chief, CEERD-CN; and Alan Anderson, CEERD-CZT, was the Technical Director for Environmental Quality. The Deputy Director of ERDC-CERL was Dr. Kirankumar Topudurti and the Director was Dr. Lance Hansen.

The authors would like to thank Tammy Veillon, Terrill Turner, Bruce Martin and Wayne Fariss, Fort Polk; Barry G. Dorman, Robert A. Icenogle, and Morris G. Welch, USDA-Agricultural Research Service, National Soil Dynamics Laboratory; Dick Gebhart (retired), Pat Guertin and Dylan O'Hearn, U.S. Army Construction Engineering Research Laboratory; Sarah Kania and Chris Castle, University of Illinois; and Robyn Barbato, U.S. Army Cold Regions Research and Engineering Laboratory.

The Commander of ERDC was COL Teresa A. Schlosser and the Director was Dr. David W. Pittman. 


\section{Table of Contents}

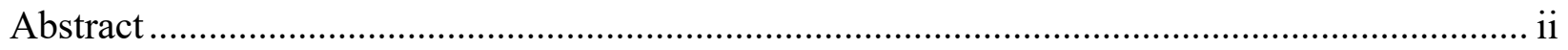

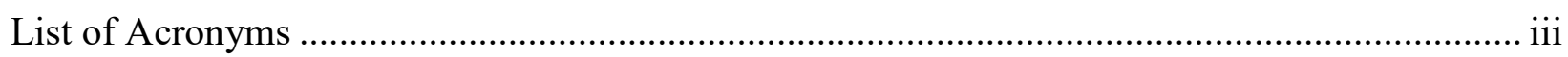

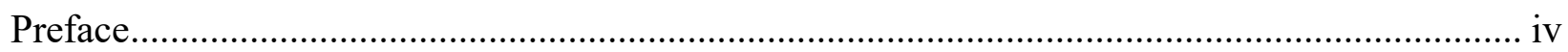

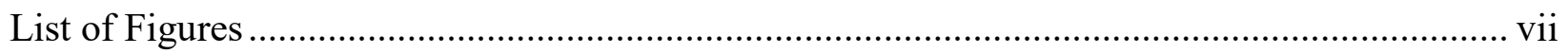

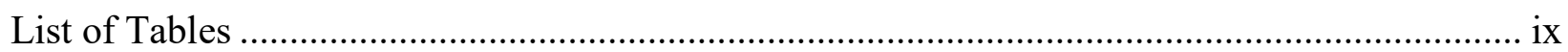

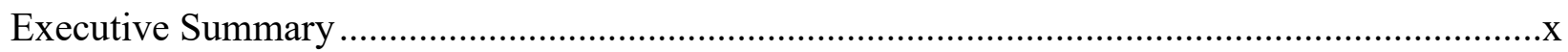

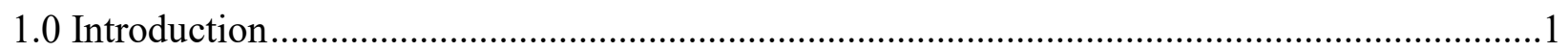

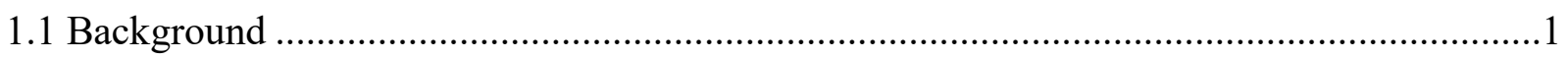

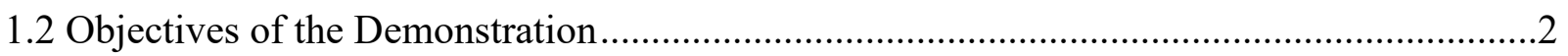

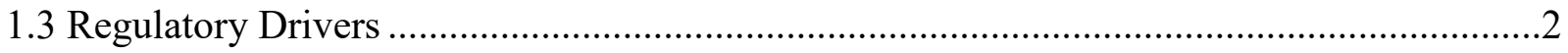

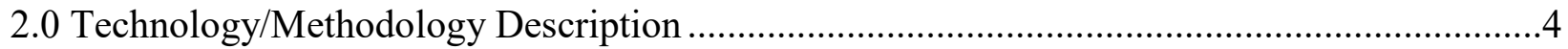

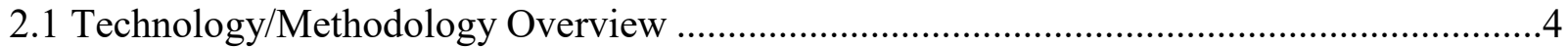

2.2 Technology/Methodology Development..........................................................................

2.3 Advantages and Limitations of the Technology/Methodology ............................................10

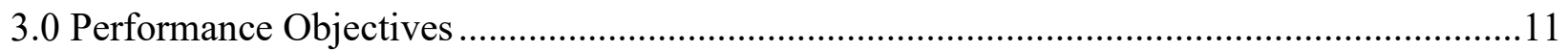

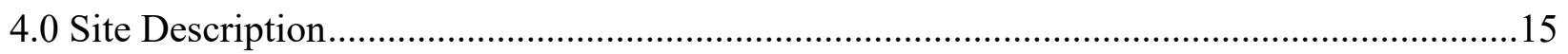

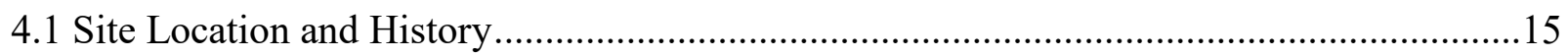

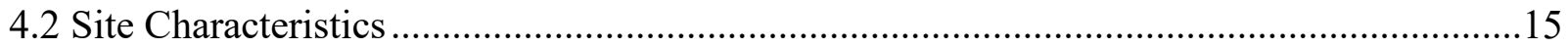

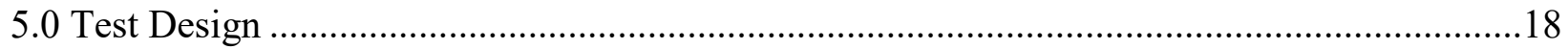

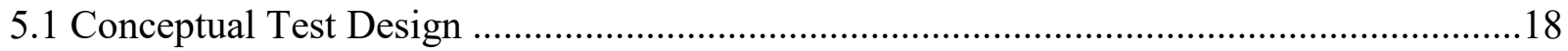

5.2 Baseline Characterization and Preparation..........................................................................19

5.3 Design and Layout of Technology and Methodology Components.....................................20

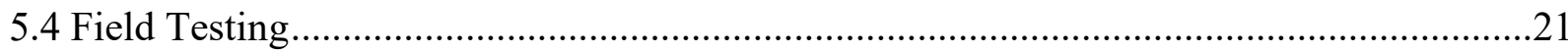

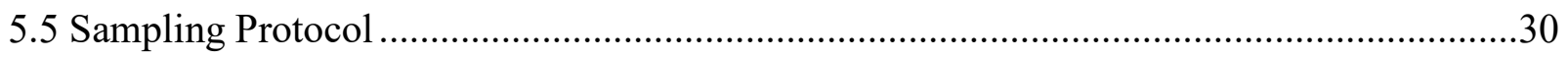

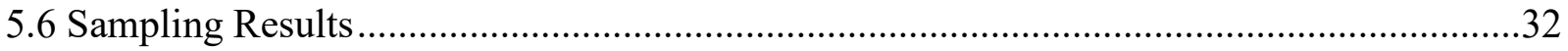




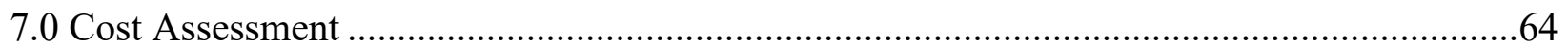

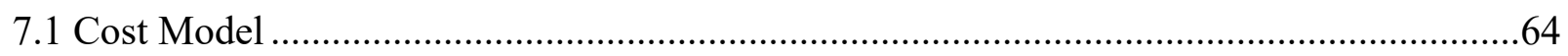

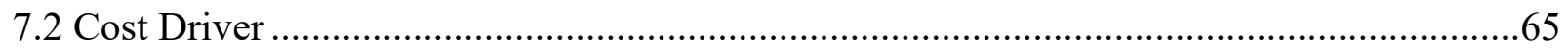

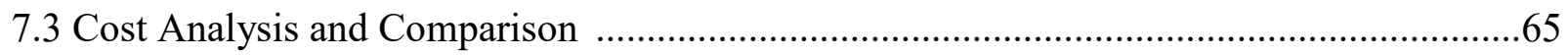

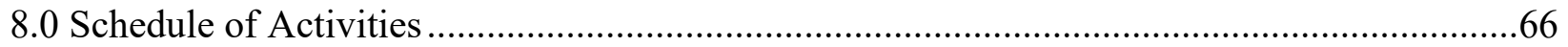

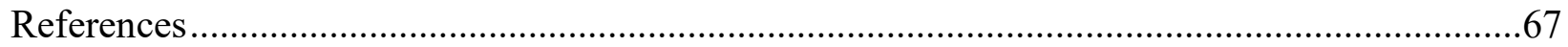

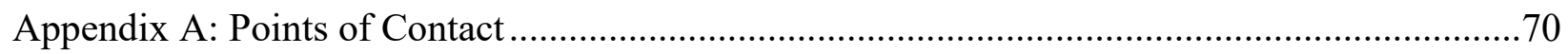

Appendix B: Equipment Calibration and Data Quality Issues .............................................71 


\section{List of Figures}

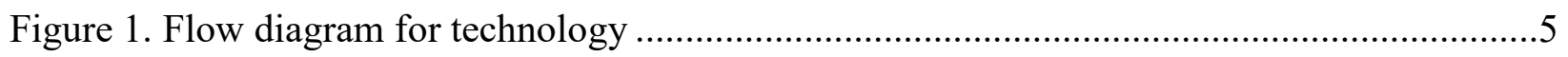

Figure 2. Approximately 1 ton of pulverized paper in the rented rolloff container.........................7

Figure 3. Batch-collected paper collected by a contractor.......................................................

Figure 4. Close-up of a small batch-collected waste paper source ……….....................................

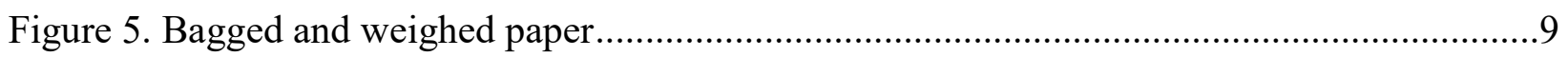

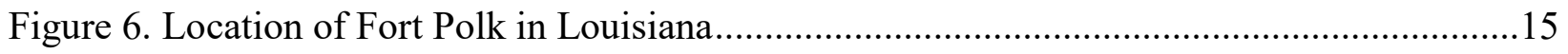

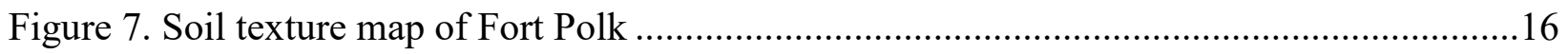

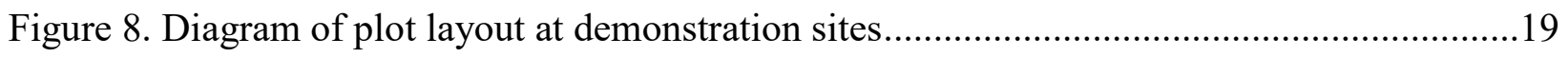

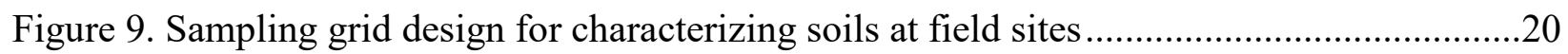

Figure 10. Bagged and weighed paper awaiting transport to demonstration sites.........................22

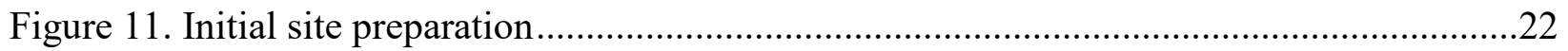

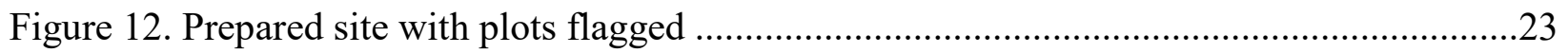

Figure 13. Weighed paper placed into respective plots to achieve desired application rates ........23

Figure 14. Paper removed from bags and awaiting final spreading ...........................................24

Figure 15. Paper is spread evenly over plots and awaiting incorporation ....................................24

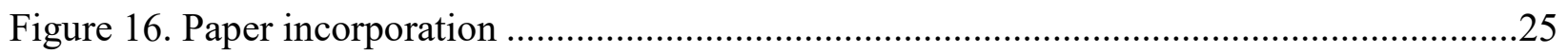

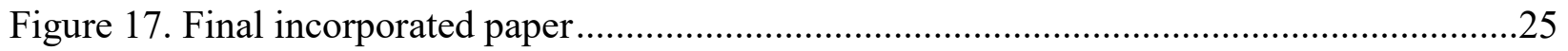

Figure 18. Site checkup one month after incorporation of paper ...............................................26

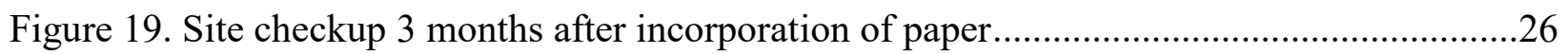

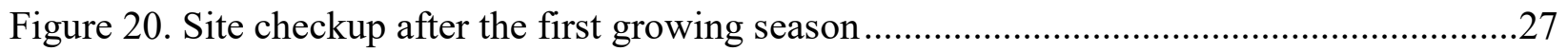

Figure 21. Biomass cutting after the first growing season.........................................................27

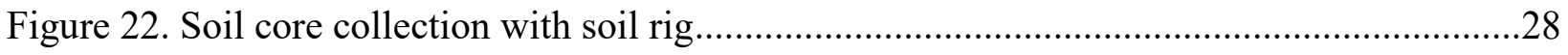

Figure 23. Soil cores stored in tubes to be sectioned by depth and analyzed .................................28

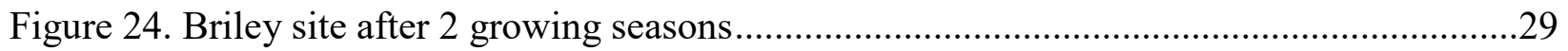

Figure 25. High paper application rate after 2 growing seasons..............................................29

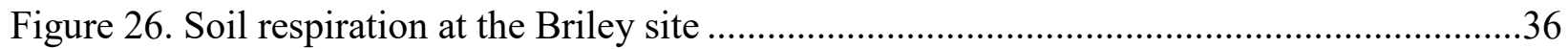

Figure 27. Mean total basal vegetative cover at the Briley site ..................................................

Figure 28. Mean planted grass basal cover at the Briley site.....................................................

Figure 29. Mean relative planted basal grass cover at the Briley site...........................................39

Figure 30. Mean relative weed basal cover at the Briley site ...................................................40

Figure 31. Mean total basal vegetative cover at the Eastwood site ..............................................41

Figure 32. Mean planted grass basal cover at the Eastwood site................................................42

Figure 33. Mean relative planted grass basal cover at the Eastwood site.......................................43 
Figure 34. Mean relative weed basal cover at the Eastwood site .44

Figure 35. Mean total biomass at the Briley site .... .45

Figure 36. Mean planted grass relative biomass at the Briley site... .46

Figure 37. Mean total biomass at the Eastwood site.. .47

Figure 38. Mean planted grass relative biomass at the Eastwood site. .48

Figure 39. Soil C:N ratios at the Eastwood site. .61

Figure 40. Soil C:N ratios at the Briley site. .62 


\section{List of Tables}

Table 1. Chronological summary of technology development .......................................................6

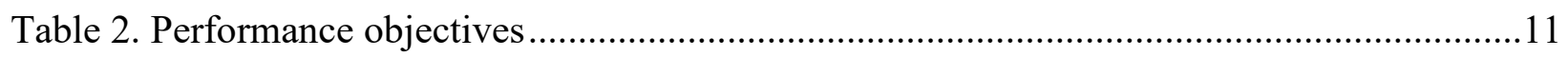

Table 3. Normal ranges of plant nutrients in native grasses and soils ........................................13

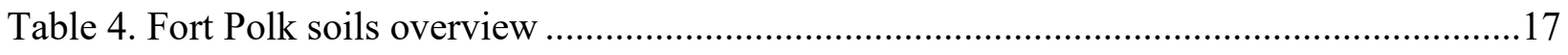

Table 5. Paper application rates applied to the two demonstration sites .....................................18

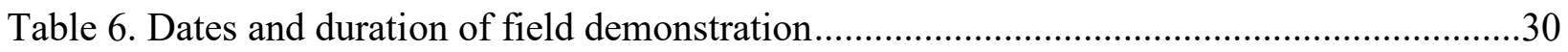

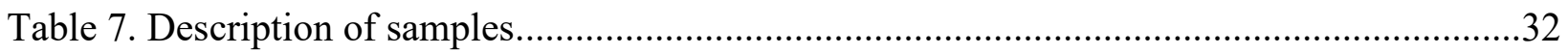

Table 8. Mean bisphenol A and phthalate concentrations in Fort Polk pulverize

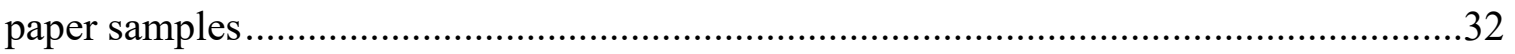

Table 9. Mean heavy metal concentrations of Fort Polk pulverized paper samples........................33

Table 10. Agricultural analysis of pulverized paper samples .......................................................

Table 11. Contaminants in spiked paper samples representing worst-case scenarios .....................34

Table 12. Heavy metal contaminants in paper samples from multiple installations .......................35

Table 13. Agricultural properties of paper samples across multiple installations ...........................35

Table 14. Macronutrient concentrations in planted grasses........................................................49

Table 15. Micronutrient concentrations in planted grasses .......................................................50

Table 16. Soil bulk density and concentration and content of $\mathrm{C}$ and plant macronutrients

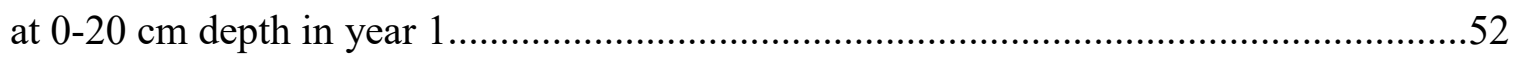

Table 17. Soil concentration and content of plant micronutrients at $0-20 \mathrm{~cm}$ depth in year 1 .....53

Table 18. Soil concentration and content of metals at $0-20 \mathrm{~cm}$ depth in year 1 ............................54

Table 19. Soil bulk density and concentration and content of $\mathrm{C}$ and plant macronutrients

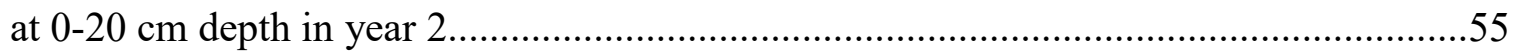

Table 20. Soil concentration and content of plant micronutrients at $0-20 \mathrm{~cm}$ depth in year $2 \ldots . . .56$

Table 21. Soil concentration and content of metals at $0-20 \mathrm{~cm}$ depth in year $2 \ldots \ldots \ldots \ldots \ldots \ldots \ldots \ldots \ldots . . . .57$

Table 22. Soil $\mathrm{pH}$ and concentration of extractable plant macronutrients at $0-20 \mathrm{~cm}$ depth

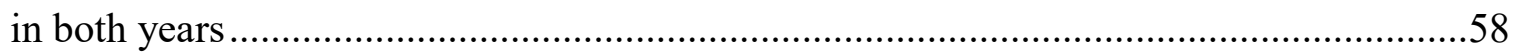

Table 23. Correlations between paper application rate and deficient plant nutrient concentrations at both sites ......................................................................................6

Table 24. Correlations between paper application rate and deficient soil nutrient

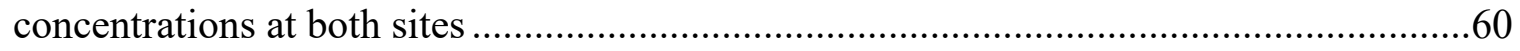

Table 25. Soil concentration changes in EPA-regulated heavy metals .........................................63

Table 26. Cost model for pulverized paper demonstration...........................................................64 


\section{Executive Summary}

\section{Background}

All DoD organizations are required to adhere to strict federal guidelines for the destruction of classified documents, compact discs, slides, Top Secret mylar communications film, and COMSEC. Further, medical records must be disposed of securely, with an option for cross-cut shredding/pulverization at the Army's 42 hospitals. For security purposes, the majority of these organizations perform their document destruction onsite, often using industrial-sized shredders to accommodate large volumes of documents. Federal regulations require that Top Secret documents be pulverized to $0.9 \times 4.2 \mathrm{~mm}$, the smallest size required for classified documents. These pulverized pieces cannot be recycled by the paper industry since the fibers have been cut too short for reuse in the manufacturing of paper products. Many DoD facilities pulverize all of their documents for convenience and manpower/equipment operating efficiency, resulting in paper wastes that are often combined with other solid waste and landfilled. This adds to operational costs for the collection, transport, and disposal of pulverized paper, and directly conflicts with DoD's aggressive sustainability policies. To resolve these issues, a successful method for reuse of this pulverized paper must be identified.

In a separate problem, DoD installations often experience significant erosion of training ranges. The primary mission for DoD is training the Warfighter, and preservation of military training lands is critical. To sustain this mission, technologies for mitigating erosion and rehabilitating degraded training lands must be validated and accepted. Disturbed military training and testing lands are almost always reseeded with native warm season perennial grasses. Because native warm season perennial grasses are adapted to nutrient poor soils, oversupplying nutrients is detrimental to them and often results in failure. Adequate soil restoration to reduce this overabundance of available nutrients often requires massive quantities of organic matter, but locating suitable additives is difficult and expensive. Pulverized paper is an ideal source of organic matter to rehabilitate damaged soils and support native vegetation. This material has been previously overlooked as a $\mathrm{C}$ source for degraded soils. Utilization of this material could improve sustainability initiatives implemented by DoD, by not only improving training land conditions, but by diverting a significant waste stream from landfills as well.

High $\mathrm{C}$, wood-derived waste materials low in available $\mathrm{N}$ have been investigated thoroughly for their potential use as soil amendments to improve native vegetation establishment. In highly degraded soils lacking productivity, high $\mathrm{C}$ waste materials provide long lasting improvements to soil and vegetation. Alternatively, in disturbed productive soils, high $\mathrm{C}$ waste materials effectively immobilize $\mathrm{N}$, favoring establishment of desirable perennial native vegetation. The technology demonstrated for this project is very simple: guidance does not exist for the utilization of pulverized paper for training land rehabilitation. As a readily available high $\mathrm{C}$ source, pulverized paper overcomes a significant hurdle to the use of high $\mathrm{C}$ organic amendments: the cost.

What remains to be accomplished is demonstration and validation of this technology using a readily available high $\mathrm{C}$ waste source in an operational environment to document cost-effective utilization and provide a means for technology transfer. This project will demonstrate and 
validate the use of pulverized paper for rehabilitation of degraded training lands, and identify the optimal application rate of this material in an operational setting. The performance of standard land rehabilitation plant species and techniques will be used for a direct comparison with their performance in previous investigations using other high $\mathrm{C}$ waste materials.

\section{Objectives}

The purpose of this project is to conduct an operational demonstration and validation to utilize pulverized paper as a source of organic matter for degraded soils, and validate the creation of soil conditions commensurate with establishment of native vegetation on disturbed $\mathrm{DoD}$ training lands.

The goal of this project is to demonstrate and validate the cost-effective utilization of pulverized classified paper waste as an organic soil amendment for rehabilitation of severely disturbed training lands. Objectives include: demonstrating improved vegetative cover and soil and plant health using pulverized paper as a soil amendment, validating the economic benefits of this utilization versus current practices for waste disposal and training land management, assessing potential paper waste contaminants to identify associated potential restrictions, and developing user guidelines for transfer of this technology to end users. This proposed demonstration/ validation project not only addresses a unique DoD problem in managing large volumes of classified paper wastes, but addresses several high priority Army environmental requirements as well in a cost-effective manner.

This project will provide a unique solution for reuse of pulverized classified documents. As DoD is the largest US producer of classified documents, providing an alternative to landfilling this pulverized paper will result in reduced operational costs while simultaneously supporting objectives and goals of the DoD Strategic Sustainability Performance Plan. This plan seeks to minimize and optimally manage solid wastes through reduced usage of printing paper, and a $50 \%$ diversion of non-hazardous solid waste from the waste stream to beneficial reuse. The successful mitigation of erosion and rehabilitation of $\mathrm{DoD}$ training ranges will ensure continued use for critical training, and maintain environmental stewardship of land assets in a cost-effective manner.

\section{Technology Description}

Pulverized paper, with a $\mathrm{C}: \mathrm{N}$ ratio of around 200, is an ideal source of organic matter to rehabilitate damaged soils and support native vegetation (Figure 1). This material has been previously overlooked as a $\mathrm{C}$ source for degraded soils, and could improve sustainability initiatives implemented by DoD, by not only improving training land conditions, but also by diverting a significant waste stream from landfills. The technology demonstrated for this project is very simple: guidance does not exist for the utilization of pulverized paper for training land rehabilitation. As a readily available high $\mathrm{C}$ source, pulverized paper overcomes a significant hurdle to the use of high $\mathrm{C}$ organic amendments: the cost.

Alternative technologies that exist for $\mathrm{N}$ immobilization are sucrose, sawdust, and other high $\mathrm{C}$ anthropogenic wastes. Advantages of the proposed technology over other technologies are availability, cost, and purity. Sucrose is the purest high $\mathrm{C}$ source, but its cost makes it unfeasible 
for large-scale utilization. Sawdust can be contaminated or pure, but its primary limitations are availability and cost. Most high $\mathrm{C}$ anthropogenic wastes are available and inexpensive, but contamination is high. Pulverized paper is low in contaminants (Table 1), widely available to the military, and associated costs are low. Major cost considerations are transportation to locations where it will be used and incorporation. However, because transportation costs are already incurred for removal, and current restoration activities already utilize mechanical devices to mix soil, this proposed technology can be repurposed for less than what current disposal and rehabilitation practices cost.

Table ES1. Mean heavy metal concentrations of Fort Polk pulverized paper samples. Metals with values preceded by " $<$ " were below detection limits for all samples; therefore, the detection limits are presented.

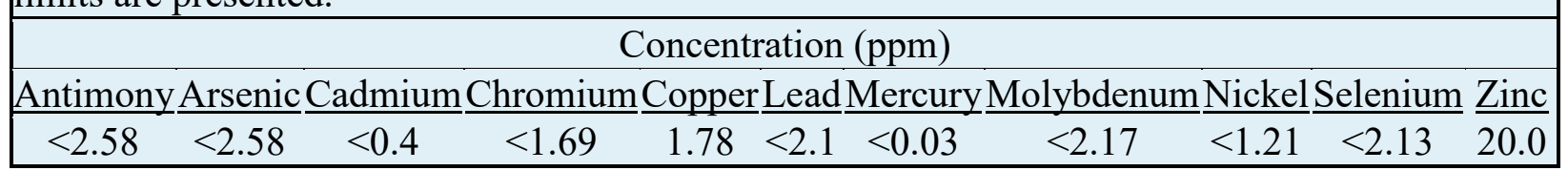

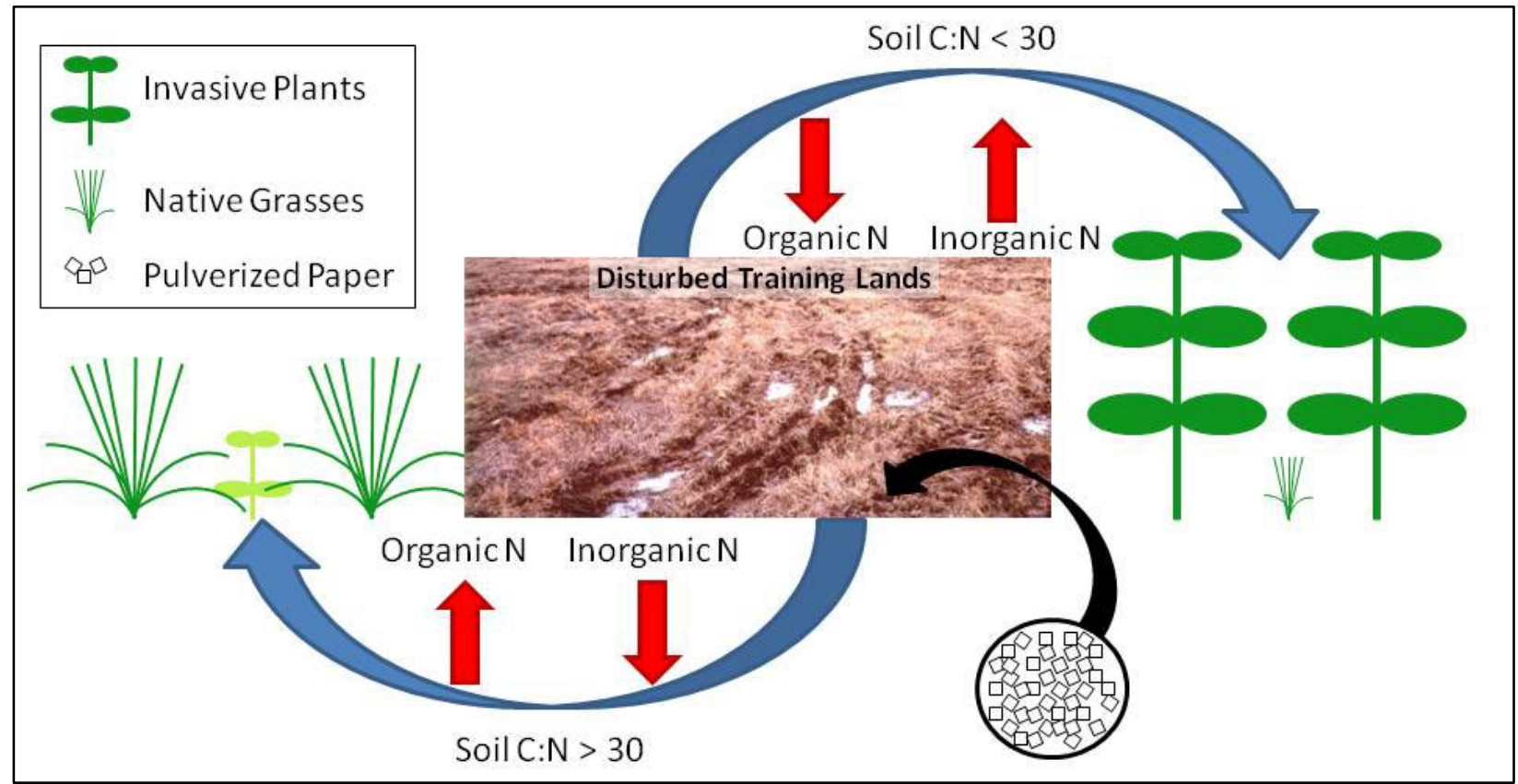

Figure ES1. Flow diagram for technology. Disturbed training lands have high inorganic N concentrations that favor invasive plant dominance. Adding a high $\mathrm{C}$ waste such as pulverized paper stimulates microbial immobilization of inorganic $\mathrm{N}$ into organic $\mathrm{N}$, favoring native grass dominance.

Limitations of the technology include the need to store the material in an enclosure that prevents wind transportation, as well as the requirement that applications occur on more or less calm days. Volume availability also limits the applicability of the technology. Volumes produced by most installations will likely only allow annual treatment of a small area (likely in the range of 2-8 ha (5-20 ac)) of highly disturbed sites at the highest application rates. A larger area (likely in the range of 8-32 ha (20-80 ac)) can be treated at lower application rates. This demonstration/ 
validation will indicate what levels of change are observed across the range of application rates. This will allow end user utilization in the most effective manner given volume constraints. A further limitation is the seasonal effectiveness of the technology. To prevent offsite migration of the material, sites of application should be prepared by mechanical mixing of the soil. Frozen soil will prevent utilization in winter months. In climates where soil does not freeze, application of the material could be achieved during winter months, but decomposition of the material and nutrient immobilization could occur on a timescale that does not provide the greatest benefit to desirable native warm season perennial grasses if vegetation is not seeded and germinates soon after the material is applied.

Due to multiple sources of pulverized paper across Fort Polk producing varying volumes of material, 2 separate collection efforts were conducted. Large sources of paper that were stored in dumpsters at their respective sources were collected using a 20 cubic yard rolloff container placed at the edge of a parking lot. Instead of emptying these dumpsters in garbage trucks for transport to the landfill, waste management contractors instead emptied the paper dumpsters in the rolloff container. A cover was kept over the rolloff container to prevent moisture entry. This container held approximately 3 tons of paper. Smaller sources of pulverized paper were collected by a recycling contractor. This contractor collected recycled material from collection sites across Fort Polk. The small batches of pulverized paper were placed into plastic bags and separated from other recyclable materials.

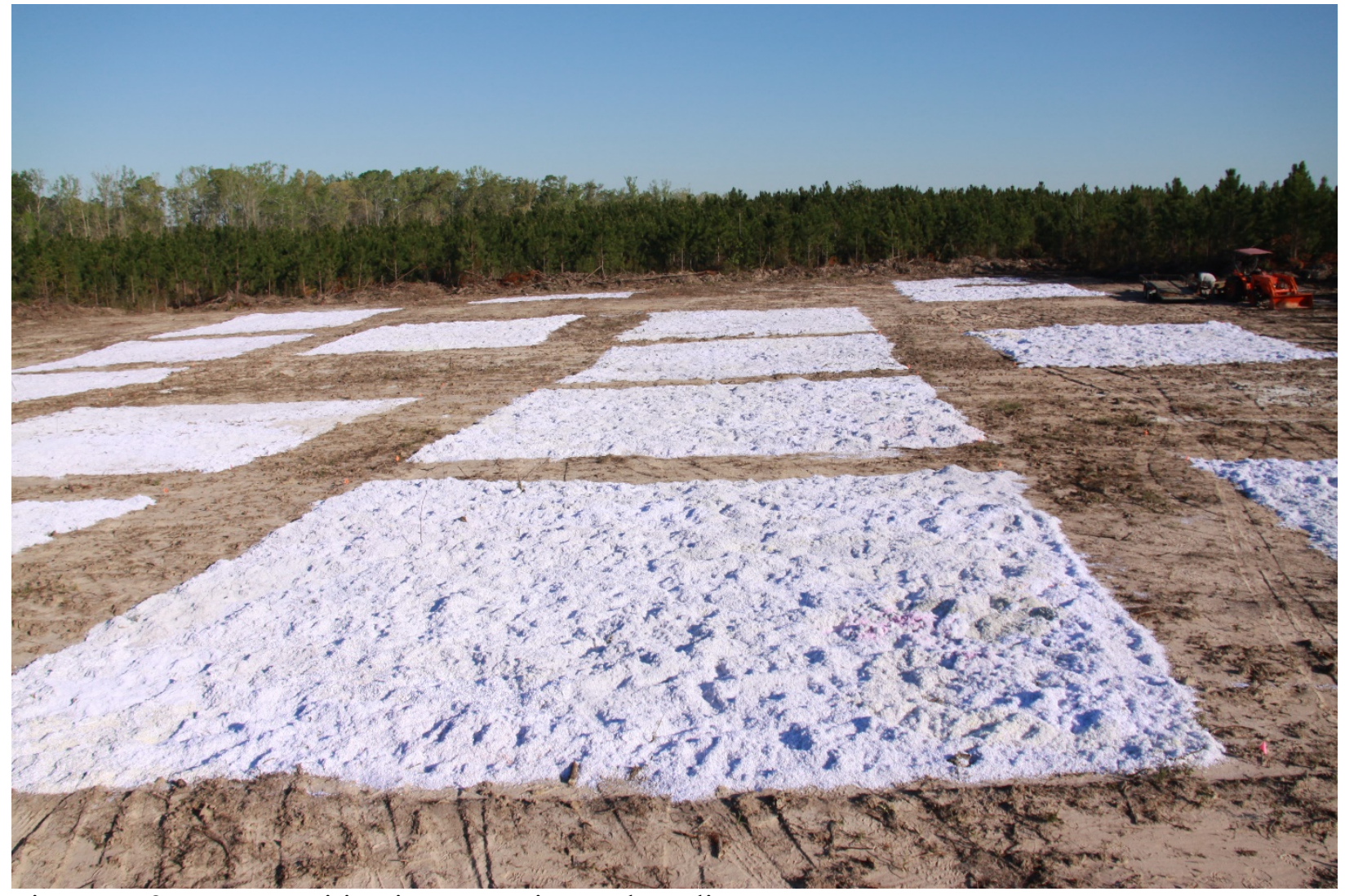

Figure ES2. Paper awaiting incorporation and seeding. 
Paper stored in the rolloff container was bagged and placed with the other paper stored in plastic bags. Because of the necessity for specific paper weights to be applied at the demonstration sites, storage in bags was necessary for accurate weighing and separation into different application rates. However, in circumstances where paper is to be applied in a similar manner, the requirement for storage in plastic bags is not necessary and is likely an impediment to efficient transportation and application to soils.

Approval for conducting this demonstration at Fort Polk, LA, was required at the state and installation levels. The Louisiana Department of Agriculture and Forestry issued a permit based on best management practices for application of the material to the soil. Fort Polk issued approval based on completion of Records of Environmental Concern for each of the two demonstration sites.

To obtain exact application rates for the demonstration, all paper was bagged in plastic bags and weighed to allow for accurate placement on field plots. Bags were weighed with a benchtop 400 pound capacity postal scale, weights were recorded on a piece of duct tape placed on the bags, and all bag weights were recorded to document total mass of paper cumulatively. Paper was then transported to the sites in a moving truck and spread by hand, disked, and seeded (Figure 2). Paper application rates above 16 tons $\mathrm{ac}^{-1}$ did not incorporate into the soil and created a thick mulch on the soil surface that restricted plant growth and retained significant amounts of moisture (Figures 3-5). Due to this impediment, paper application rates at the second demonstration site were halved compared to the first site to ensure all application rates could be incorporated.

\section{Performance Assessment}

A positive correlation was observed between paper application rate and native plant cover at both sites. A negative correlation was also observed between paper application rate and invasive plant cover at both sites. At the Briley site, native plant cover at the 32 tons acre ${ }^{-1}$ paper application rate was $42 \%$ higher than the control treatment. At the Eastwood site, native plant cover at the 16 tons acre $^{-1}$ paper application rate was $48 \%$ higher than the control treatment.

The Eastwood site alone exhibited a positive correlation between planted grass biomass and paper application rate. A negative correlation was observed between paper application rate and invasive plant biomass. At the Briley site, native plant biomass at the 32 tons acre ${ }^{-1}$ paper application rate was $71 \%$ lower than the control treatment, due to the high rate of paper forming a thick mulch on the soil surface. However, at the Eastwood site, native plant biomass at the 16 tons acre $^{-1}$ paper application rate was $90 \%$ higher than the control treatment. Although our target of a $50 \%$ increase in native plant biomass in the highest paper application rates relative to controls was not achieved (10\% average across sites), we exceeded our target at one site (90\% at Eastwood). Because of the difficulties in incorporating the high application rates into the soil, when using 16 tons acre ${ }^{-1}$ across both sites, an average of $74 \%$ is achieved, which exceeds our target. 


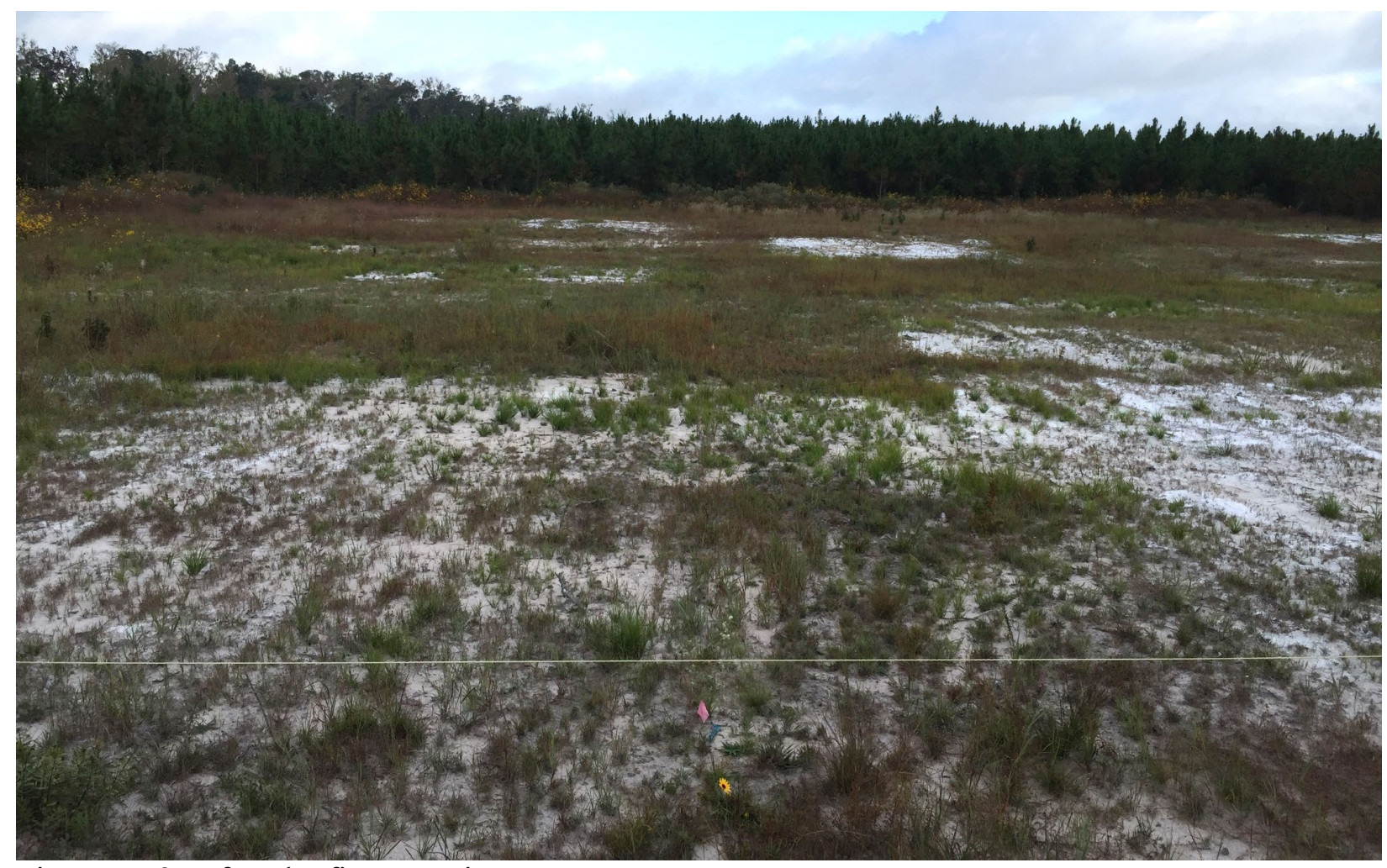

Figure ES3. After the first growing season.

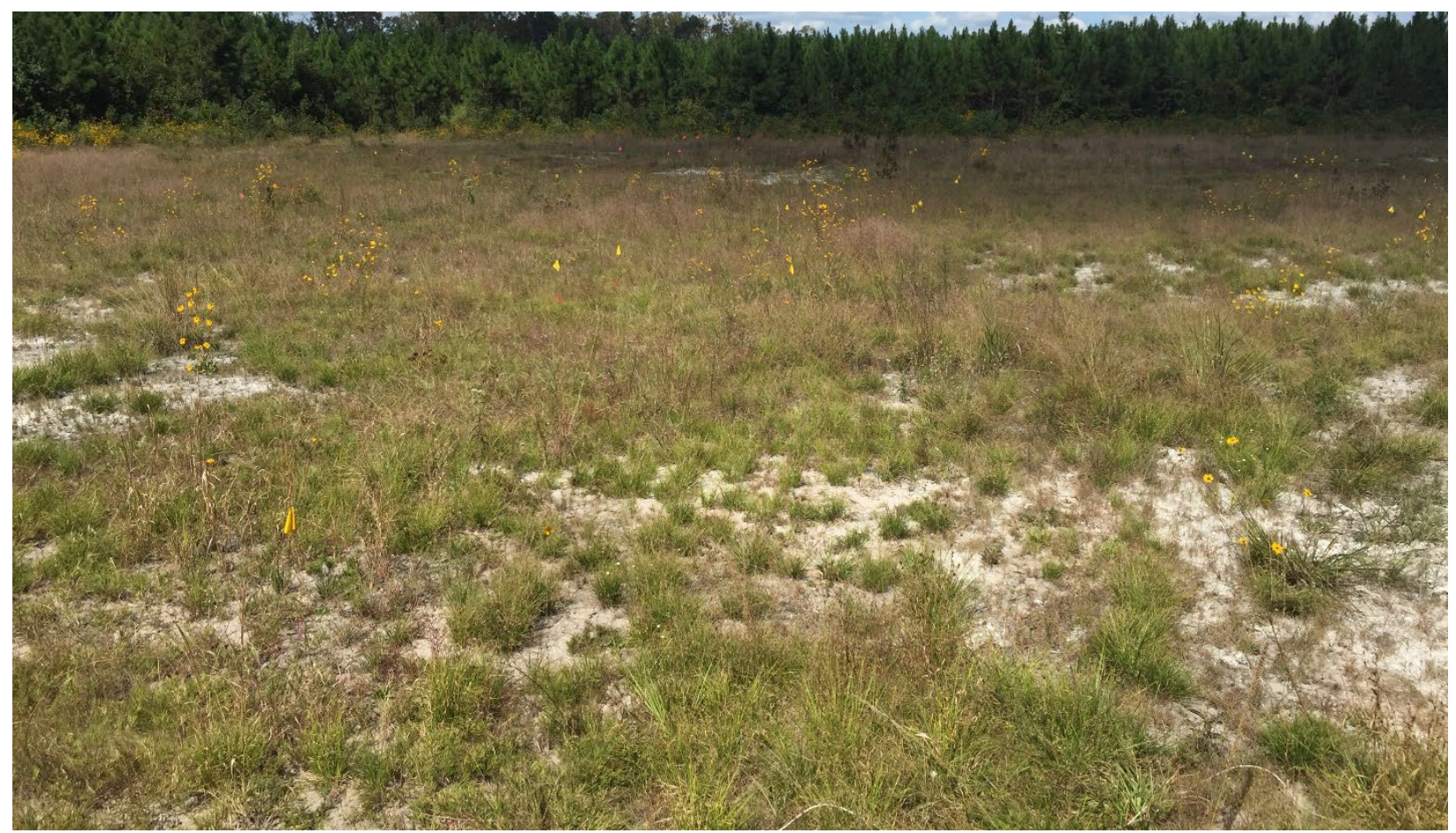

Figure ES4. After 2 growing seasons. 


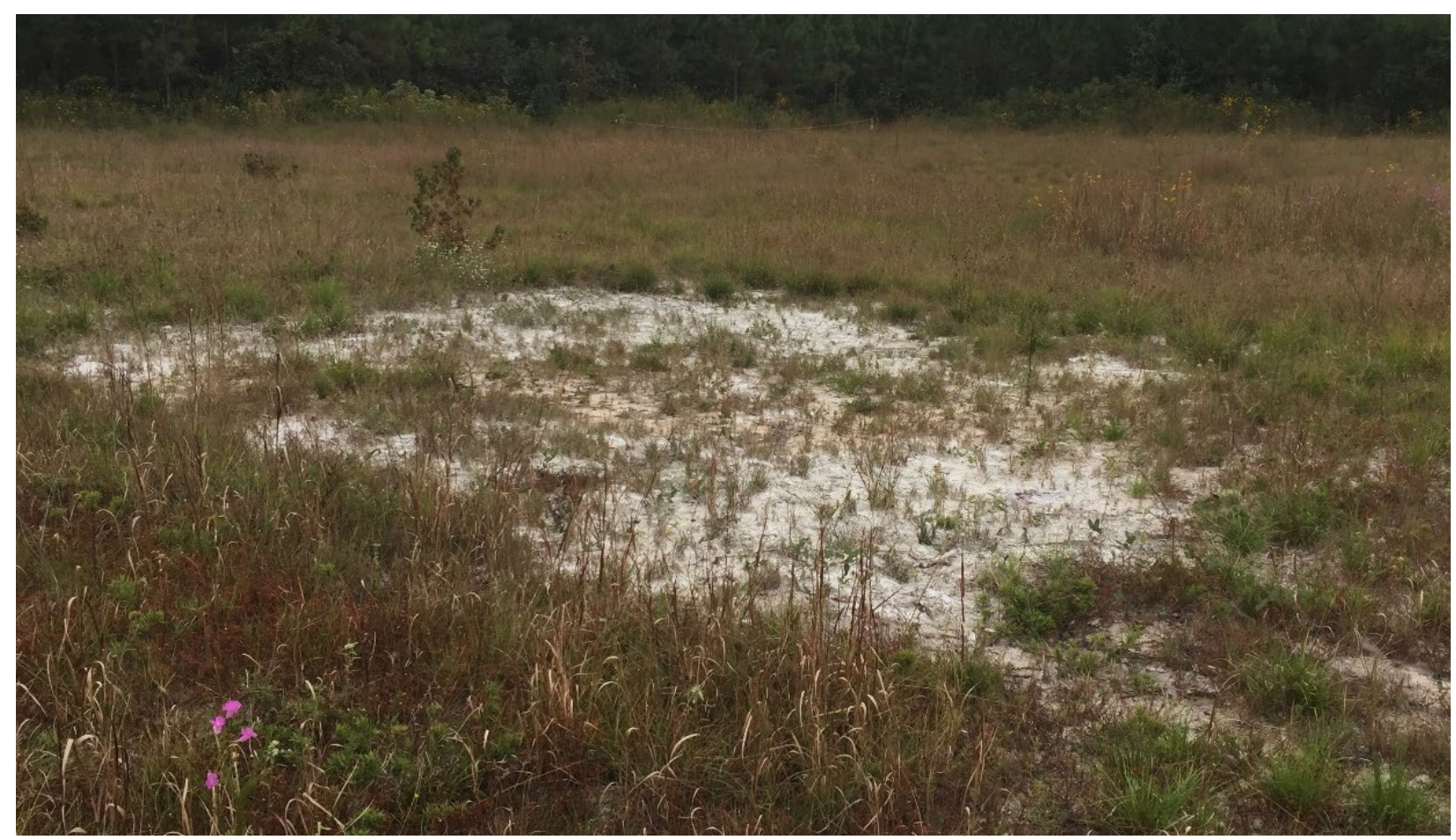

Figure ES5. Highest paper application rate after 2 growing seasons.

Plant concentrations of $\mathrm{Ca}$ and Mo were moderately correlated with paper application rate while $\mathrm{P}$ and $\mathrm{S}$ were weakly correlated at both sites. We achieved our target of positive correlation between application rate and a deficient plant nutrient concentration for both $\mathrm{Ca}$ and Mo across both sites. Soil $\mathrm{Ca}$ concentration was also correlated with paper application rate. As Ca content in the paper was high while being deficient in the soil, this is understandable.

Soil $\mathrm{pH}$ was positively correlated with paper application rate at both the Briley (Pearson correlation coefficient $=0.73, \mathrm{p}<0.001)$ and Eastwood (Pearson correlation coefficient $=0.55, \mathrm{p}$ $=0.01$ ) sites. For bulk density, paper application rate was moderately negatively correlated with bulk density (Pearson correlation coefficient $=-0.60, \mathrm{p}=0.005$ ) at the Briley site, while no correlation was observed at the Eastwood site (Pearson correlation coefficient $=-0.07, p=0.78$ ). This was likely a result of utilizing paper application rates at this site that were half of what was planned due to incorporation difficulties at the higher rates.

Contaminant concentrations for EPA-regulated heavy metals were analyzed, with the expectation that no contaminant would be increased by more than $50 \%$ at the highest application rate. No contaminant reached a level even close to that number. In fact, no significant increase was observed for any regulated metal in the highest application rates versus control treatments and no discernable increases could be attributed to paper application rates at any level for any regulated heavy metal. Because most EPA-regulated heavy metals were not detected in analyzed paper samples, a very conservative calculation of application limits is presented here based on detection limits of the analytical equipment. Using detection limits, the limiting contaminant would be molybdenum. This is based solely on its concentration limitation by the EPA in relation to the detection limits of the analytical instrument used to quantify concentrations, and in no way reflects its concentration in the paper. But using this estimate, and assuming an annual 
application of the recommended 16 tons of pulverized paper over the same acre of land every year, the cumulative EPA loading limit would be reached in 231 years.

However, if using heavy metals that were actually detected in the paper, copper and zinc (both of which are plant micronutrients), then zinc is the limiting factor. At an annual paper application rate of 16 tons, our recommended pulverized paper application rate, the cumulative EPA loading limit would be reached in 3,900 years.

\section{Cost Assessment}

Fort Polk paper disposal costs for landfill placement run at $\$ 175$ per ton. Collection and storage of the paper from small batch sources did not incur an additional cost as it was included in a contract for collection of all recyclable materials from the same collection locations. Storage of the larger batches of paper required rental of a rolloff container. The 20 cubic yard rolloff cost $\$ 114$ per month, with a one-time charge of $\$ 250$ for dropoff and pickup. This rental was required due to our bagging and weighing for exact application rates and would not be necessary for full implementation. Thus, this cost was not included in the final cost calculations. However, if storage in a rolloff(s) container is deemed desirable, purchasing or acquiring an excess container would be cost effective. Because storage occurred in unused buildings, the storage cost for paper was $\$ 0$. Outside storage could be an option if blowing paper deposition in the area immediately surrounding the storage location is acceptable. Wetting the paper a single time causes the paper particles to stick together, which significantly reduces wind movement. Storage of paper in this way in an empty lot with a water hydrant would likely be most cost effective and easiest to store and load bulk paper material. Transport of bulk materials costs $\$ 0.40$ per ton per mile at Fort Polk. Our overall cost estimate used this number and an average distance of 15 miles for collection and disposal at a training land, giving an overall paper disposal cost of $\$ 6.00$ per ton.

Because site preparation with a disk is not performed at every location, this additional cost of site preparation was included, although at other locations this will likely not be the case. Because most installation land management departments already own a disk, acquisition costs are not included. Tractor operation costs for disking average close to $\$ 8$ per acre nationwide, with an additional \$21 labor cost per acre for disking (\$42 per hour labor at a disking rate of 2 acres per hour). No other site preparation costs are required to incorporate pulverized paper into disturbed training lands undergoing rehabilitation.

At the recommended 16 tons per acre rate (and a cost of $\$ 96$ for incorporation on 1 acre of land), the benefits will include an average reduction in bulk density of $5 \%$, a $20 \%$ increase in $\mathrm{pH}(1$ unit), a $40 \%$ increase in soil carbon, a $10 \%$ increase in basal cover of planted grasses, a $25 \%$ decrease in weed basal cover, and more than double the biomass of native warm season grasses.

Current estimates indicate that costs associated with Army land rehabilitation are $\$ 2,000$ per acre $\left(\$ 4940 \mathrm{ha}^{-1}\right)$ and $50 \%$ of all rehabilitation activities on these lands fail. This assessment is supported by the literature, where published analyses indicate that only $52 \%$ of restoration goals are achieved (Lockwood and Pimm, 1999). An additional analysis of 82 published reports and a global survey indicates that for year-old restorations in unprotected sites the success rate is $50 \%$, but drops to $25 \%$ after 3 years (Godefroid et al., 2011). Assuming that half of all land rehabilitation actions currently must be repeated after 1 year and 3/4 must be repeated after 3 
years, a 3 year life cycle cost for current practices is twice the estimated per unit cost. This number is based on half of the original sites requiring additional rehabilitation in year 2 , while a quarter of the original sites require additional rehabilitation in year 3 along with half of the rerehabilitated sites from year 2 . Assuming $50 \%$ of failures are overcome with the addition of paper, the cost savings on a per acre basis amount to $\$ 2000$ per acre.

The most important consideration for cost is paper movement. This single consideration will ultimately determine the cost effectiveness of technology implementation. Collection of paper from multiple sources and variable production rates will differ significantly both within and between installations. Smaller batches require greater collection times, removal from plastic bags, and disposal of plastic bags. Bulk materials can be collected and dumped easily from bulk containers, but requires larger equipment. Storage in an area that can be accessed by loaders and dump trucks will make paper utilization much more cost effective.

Current costs for disposal are $\$ 175$ per ton. Current land rehabilitation costs are $\$ 4000$ per acre when factoring in repeated efforts due to failure. Paper transportation costs $\$ 0.40$ per ton per mile using a tandem axle dump truck with 10 to 14 cubic yard capacity. Site preparation costs $\$ 8$ to disk paper in and $\$ 21$ in labor to operate, with an overall cost of $\$ 29$. Assuming an average distance from the paper source to the incorporation site of 15 miles, and utilizing a rate of 16 tons of paper per acre, the average acre will cost $\$ 96$ to transport paper and $\$ 29$ to incorporate it, for a grand total of $\$ 125$ per acre, or approximately $\$ 8$ per ton. This alone saves approximately $\$ 167$ per ton compared to landfill disposal. Assuming the addition of paper reduces rehabilitation failures by $50 \%$, this results in a cost savings of $\$ 2000$ per acre, or $\$ 125$ per ton of paper.

Overall, the cost savings realized from diversion of pulverized paper waste from landfills to degraded training lands is $\$ 4,672$ per acre, or $\$ 292$ per ton of paper diverted. As the average installation likely disposes pulverized paper at a rate of 70 tons per year (based on populations of installations relative to Fort Polk and an assumption of similar per capita paper production rates), this could result in cost savings of $\$ 20,000$ per installation per year, and a diversion of 70 tons of paper from the waste stream. At the Service level, a cost savings greater than $\$ 1$ million per year could be realized.

\section{Implementation Issues}

Implementation required a permit from the Louisiana Department of Agriculture and Forestry for land application of the paper. Most states likely require a similar permit, but specific details will probably vary. Due to the novelty of the paper material, the exact permit that was applicable was not known. This caused a 1 year delay in implementation as initially it was decided that no permit was required, but later the permit was requested. Land application of wastes are often required to adhere to 40 CFR Part 503 (Land Application of Sewage Sludge) at a minimum, and states may have more stringent requirements for one or all regulated contaminants.

A primary concern raised during site selection was the creation of an eyesore with paper material covering the soil surface. Due to this concern, our demonstration sites were moved from areas near highly traversed roadways to less frequented areas. 


\subsection{INTRODUCTION}

\subsection{BACKGROUND}

All DoD organizations are required to adhere to strict federal guidelines in the destruction of classified documents, compact discs, slides, Top Secret Mylar communications film, and COMSEC. Further, medical records must be disposed of securely, with an option for cross-cut shredding/pulverization at the Army's 42 hospitals. For security purposes, the majority of these organizations perform their document destruction onsite, often using industrial-sized shredders to accommodate large volumes of documents. Federal regulations require that Top Secret documents be pulverized to $0.9 \times 4.2 \mathrm{~mm}$, the smallest size required for classified documents. These pulverized pieces cannot be recycled by the paper industry since fibers have been cut too short for reuse in the manufacturing of paper products. Many DoD facilities pulverize all of their documents for convenience and manpower/equipment operating efficiency, resulting in paper wastes that are often combined with other solid waste and landfilled. This adds to operational costs for the collection, transport, and disposal of pulverized paper, and directly conflicts with DoD's aggressive sustainability policies. To resolve these issues, a successful method for reuse of this pulverized paper must be identified.

In a separate problem, DoD installations often experience significant erosion of training ranges. The primary mission for DoD is training the Warfighter, and preservation of military training lands is critical. To sustain this mission, technologies for mitigating erosion and rehabilitating degraded training lands must be validated and accepted. Disturbed military training and testing lands are almost always reseeded with native warm season perennial grasses. Because native warm season perennial grasses are adapted to nutrient poor soils, oversupplying nutrients is detrimental to them and often results in failure (Wedin and Tilman, 1996). Adequate soil restoration often requires massive quantities of organic matter, but locating suitable additives is difficult and expensive. Pulverized paper is an ideal source of organic matter to rehabilitate damaged soils and support native vegetation. This material has been previously overlooked as a $\mathrm{C}$ source for degraded soils. Utilization of this material could improve sustainability initiatives implemented by DoD, by not only improving training land conditions, but by diverting a significant waste stream from landfills as well.

High $\mathrm{C}$, wood-derived waste materials low in available $\mathrm{N}$ have been investigated thoroughly for their potential use as soil amendments to improve native vegetation establishment (Morgan, 1994; Zink and Allen, 1998; Alpert and Maron, 2000; Blumenthal et al., 2003; Eschen et al., 2007). In highly degraded soils lacking productivity, high $C$ waste materials provide long lasting improvements to soil and vegetation (Zink and Allen, 1998; Busby et al., 2006; Torbert et al., 2007; Watts et al., 2012a,b). Alternatively, in disturbed productive soils, high C waste materials effectively immobilize N, favoring establishment of desirable perennial native vegetation (Alpert and Maron, 2000; Blumenthal et al., 2003; Eschen et al., 2007). The technology demonstrated for this project is very simple: guidance does not exist for the utilization of pulverized paper for training land rehabilitation. As a readily available high $\mathrm{C}$ source, pulverized paper overcomes a significant hurdle to the use of high $C$ organic amendments: the cost (Perry et al., 2010). 
What remains to be accomplished is demonstration and validation of this technology using a readily available high $\mathrm{C}$ waste source in an operational environment to document cost-effective utilization and provide a means for technology transfer. This project will demonstrate and validate the use of pulverized paper for rehabilitation of degraded training lands, and identify the optimal application rate of this material in an operational setting. The performance of standard land rehabilitation plant species and techniques will be used for a direct comparison with their performance in previous investigations using other high $\mathrm{C}$ waste materials.

\subsection{OBJECTIVE OF THE DEMONSTRATION}

The purpose of this project is to conduct an operational demonstration and validation to utilize pulverized paper as a source of organic matter for degraded soils, and validate the creation of soil conditions commensurate with establishment of native vegetation on disturbed DoD training lands.

The goal of this project is to demonstrate and validate the cost-effective utilization of pulverized classified paper waste as an organic soil amendment for rehabilitation of severely disturbed training lands. Objectives include: demonstrating improved vegetative cover and soil and plant health using pulverized paper as a soil amendment, validating the economic benefits of this utilization versus current practices for waste disposal and training land management, assessing potential paper waste contaminants to identify associated potential restrictions, and developing user guidelines for transfer of this technology to end users. This proposed demonstration/ validation project not only addresses a unique DoD problem in managing large volumes of classified paper wastes, but addresses several high priority Army environmental requirements as well in a cost-effective manner.

This project will provide a unique solution for reuse of pulverized classified documents. As DoD is the largest US producer of classified documents, providing an alternative to landfilling this pulverized paper will result in reduced operational costs while simultaneously supporting objectives and goals of the FY12 DoD Strategic Sustainability Performance Plan. This plan seeks to minimize and optimally manage solid wastes through reduced usage of printing paper, and a $50 \%$ diversion of non-hazardous solid waste from the waste stream to beneficial reuse by FY15. The successful mitigation of erosion and rehabilitation of $\mathrm{DoD}$ training ranges will ensure continued use for critical training, and maintain environmental stewardship of land assets in a cost-effective manner.

\subsection{REGULATORY DRIVERS}

The Federal government is required to minimize the generation of waste, divert at least $50 \%$ of non-hazardous solid waste by the end of FY2015, and increase diversion of organic material from the waste stream (EO 13514, 2009). Installations must make every effort to maximize nonhazardous solid waste diversion (DoD, 2008). The Army is required to minimize solid waste disposal and maximize recovery and reuse (AR 200-1, 2007).

The DoD must ensure that readiness, sustainability, cost-effective policies, and the military mission are facilitated through sustained use of natural resources (DoD, 2011b). Ranges and 
operating areas shall be managed and operated to support their long-term viability and utility to meet the National defense mission. All functional elements of installation, range, and operating area management shall be integrated fully to support DoD testing and training missions (DoD, 2003). DoD shall manage its natural resources to facilitate testing and training, mission readiness, and range sustainability in a long-term, comprehensive, coordinated, and costeffective manner (DoD, 2003). All DoD natural resources conservation program activities shall work to sustain long-term ecological integrity of the resource base and ecosystem services it provides (USC, 1960). Federal agency duties also include: providing for restoration of native species and habitat conditions in ecosystems that have been invaded, conducting research on invasive species, developing technologies to prevent introduction, and providing for environmentally sound control of invasive species (EO 13112, 1999). 


\subsection{TECHNOLOGY/METHODOLOGY DESCRIPTION}

\subsection{TECHNOLOGY/METHODOLOGY OVERVIEW}

The technology demonstrated for this project is very simple: guidance does not exist for the utilization of pulverized paper for training land rehabilitation. As a readily available high $\mathrm{C}$ source, pulverized paper overcomes a significant hurdle to the use of high $\mathrm{C}$ organic amendments: the cost (Perry et al., 2010).

There are two different benefits that can be provided from the addition of high $\mathrm{C}$ materials, based on environmental conditions: improved nutrient immobilization and improved nutrient cycling. In productive soils, organic matter content is often high, and loss of organic matter often promotes rapid mineralization of nutrients (Plaster, 1992). This mineralization of $\mathrm{N}$ favors invasive and other undesirable vegetation (Vitousek and Walker, 1987). In these soils, adding a $\mathrm{C}$ source with a high $\mathrm{C}: \mathrm{N}$ ratio will immobilize $\mathrm{N}$, providing an advantage to native plants with a high $\mathrm{N}$ use efficiency over invasive plants requiring greater $\mathrm{N}$ availability (Alpert and Maron, 2000; Paschke et al., 2000; Blumenthal et al., 2003; Eschen et al., 2007; Kirkpatrick and Lubetkin, 2011; Mitchell and Baker, 2011). In less productive soils, loss of organic matter reduces the ability of disturbed soil to support vegetative cover necessary to control erosion (Plaster, 1992). In these soils, C content is often much lower, causing the soil to be susceptible to erosion and often lacking in key nutrients and moisture retention required for successful plant establishment. Adding $\mathrm{C}$ sources with a high $\mathrm{C}: \mathrm{N}$ ratio to these soils improves soil structure, increases nutrient and moisture retention, and adds small amounts of nutrients that may be necessary for successful native plant establishment without promoting undesirable plants (Zink and Allen, 1998; Busby et al., 2006; Torbert et al., 2007; Watts et al., 2012a,b).

Sources of high C soil amendments can include sucrose (McLendon and Redente, 1992; Morgan, 1994; Paschke et al., 2000; Blumenthal et al., 2003; Kirkpatrick and Lubetkin, 2011; Mitchell and Bakker, 2011), processed municipal solid waste (Busby et al., 2006; Busby et al., 2007; Torbert et al., 2007), straw (Zink and Allen, 1998; IDOT, 2012), and cellulosic wastes (Morgan, 1994; Zink and Allen, 1998; Alpert and Maron, 2000; Blumenthal et al., 2003; Eschen et al., 2007). Each of these studies have shown that un-composted wastes low in available $\mathrm{N}$ provide a suitable amendment for establishment of desirable native vegetation.

Disturbed military training and testing lands are almost always reseeded with native warm season perennial grasses. Over the long term, this vegetation is most effective at mitigating erosion and providing suitable wildlife habitat. However, these species are difficult to establish in the short term because they are slow growing and susceptible to competition with invasive plant species (Wedin and Tilman, 1993). Because native perennial vegetation is adapted to nutrient poor soils, oversupplying nutrients is detrimental to them and often results in failure (Wedin and Tilman, 1996). Adequate soil restoration often requires massive quantities of organic matter, but locating suitable additives is difficult and expensive. Further, many materials are unsuitable, as they have high $\mathrm{N}$ concentrations that encourage invasive plant growth. The C:N ratio of the material is important in determining its suitability. Poultry litter, yard wastes, biosolids, and manures have $\mathrm{C}: \mathrm{N}$ ratios less than 30, which results in an oversupply of $\mathrm{N}$ that encourages invasive plant growth. Other materials with high $\mathrm{C}: \mathrm{N}$ ratios, such as wood wastes, 
straw, high $\mathrm{C}$ anthropogenic wastes, and sucrose, can immobilize enough $\mathrm{N}$ to allow native vegetation to dominate reseeded sites (Table 1). Pulverized paper, with a $\mathrm{C}: \mathrm{N}$ ratio of around 200 , is an ideal source of organic matter to rehabilitate damaged soils and support native vegetation (Figure 1). This material has been previously overlooked as a $\mathrm{C}$ source for degraded soils, and could improve sustainability initiatives implemented by DoD, by not only improving training land conditions, but also by diverting a significant waste stream from landfills. This project will demonstrate and validate the use of pulverized paper for rehabilitation of degraded training lands, and identify the optimal application rate of this material in an operational setting. The performance of standard land rehabilitation plant species and techniques will be used for a direct comparison with their performance in previous investigations using other high $\mathrm{C}$ waste materials.

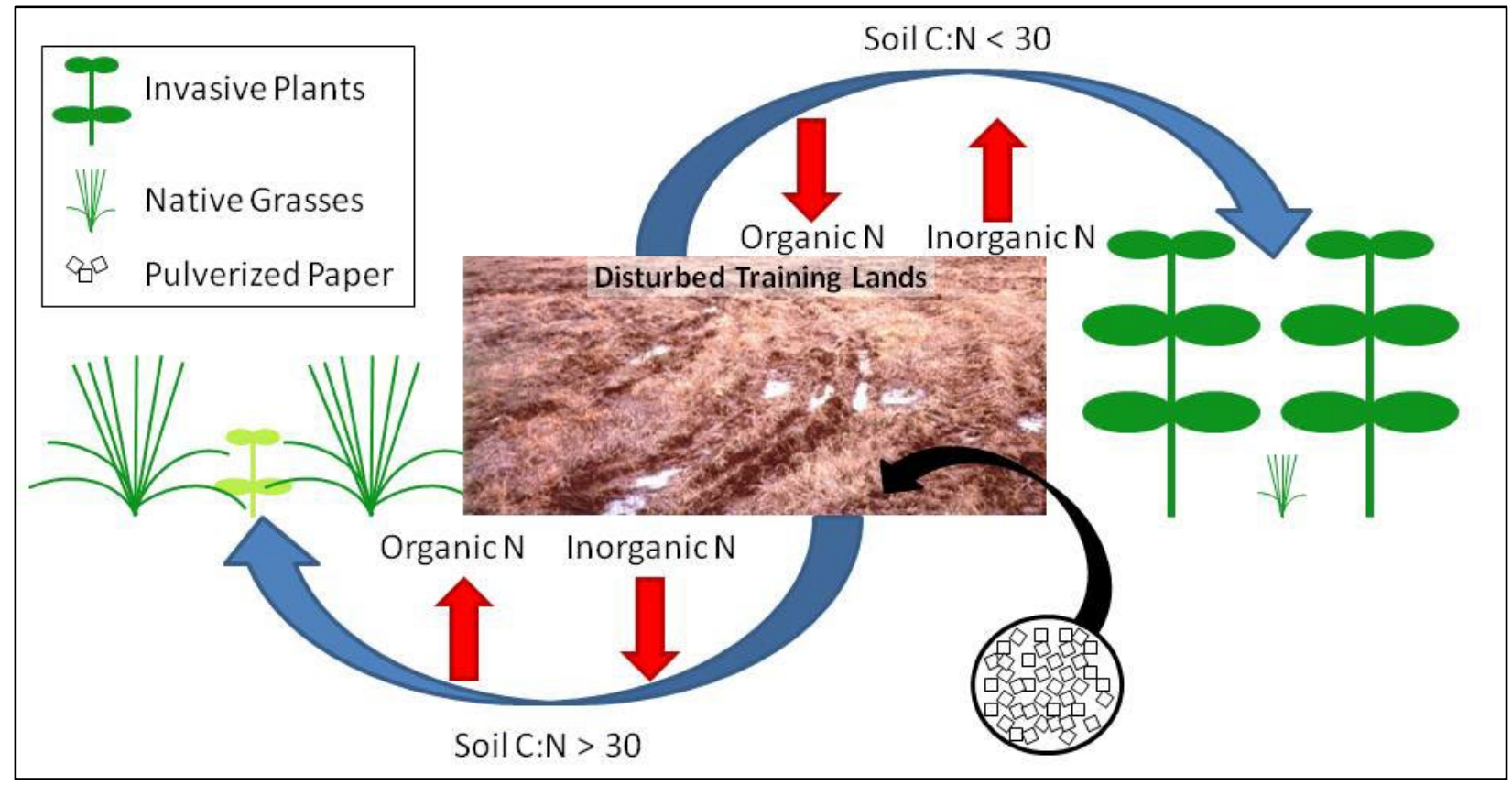

Figure 1. Flow diagram for technology. Disturbed training lands have high inorganic $\mathrm{N}$ concentrations that favor invasive plant dominance. Adding a high $\mathrm{C}$ waste such as pulverized paper stimulates microbial immobilization of inorganic $\mathrm{N}$ into organic $\mathrm{N}$, favoring native grass dominance. 


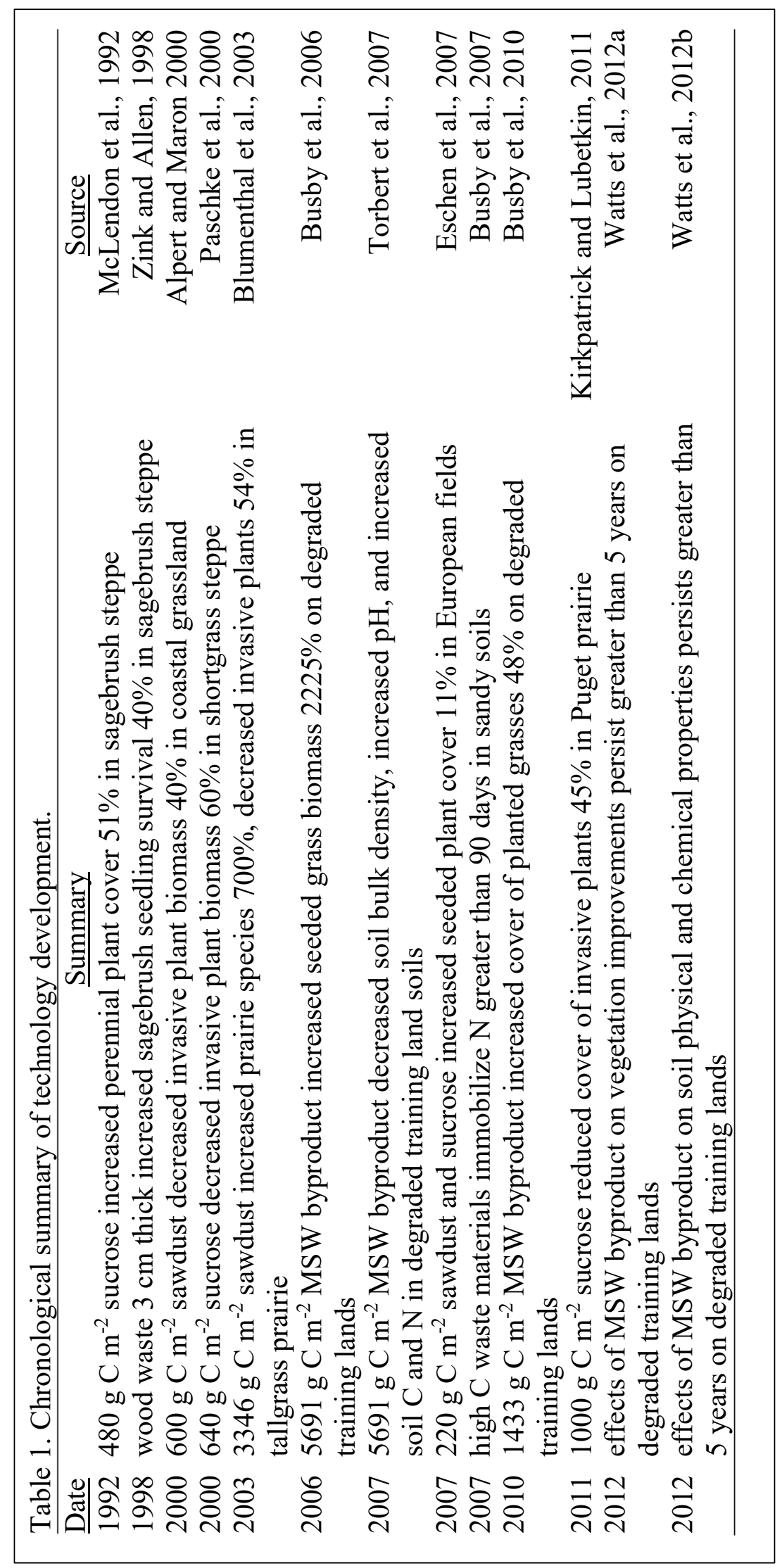




\subsection{TECHNOLOGY/METHODOLOGY DEVELOPMENT}

\section{Collection of Paper Material}

Due to multiple sources of pulverized paper across Fort Polk producing varying volumes of material, 2 separate collection efforts were conducted. Large sources of paper that were stored in dumpsters at their respective sources were collected using a 20 cubic yard rolloff container placed at the edge of a parking lot. Instead of emptying these dumpsters in garbage trucks for transport to the landfill, waste management contractors instead emptied the paper dumpsters in the rolloff container. A cover was kept over the rolloff container to prevent moisture entry. This container held approximately 3 tons of paper. Smaller sources of pulverized paper were collected by a recycling contractor. This contractor collected recycled material from collection sites across Fort Polk. The small batches of pulverized paper were placed into plastic bags and separated from other recyclable materials.

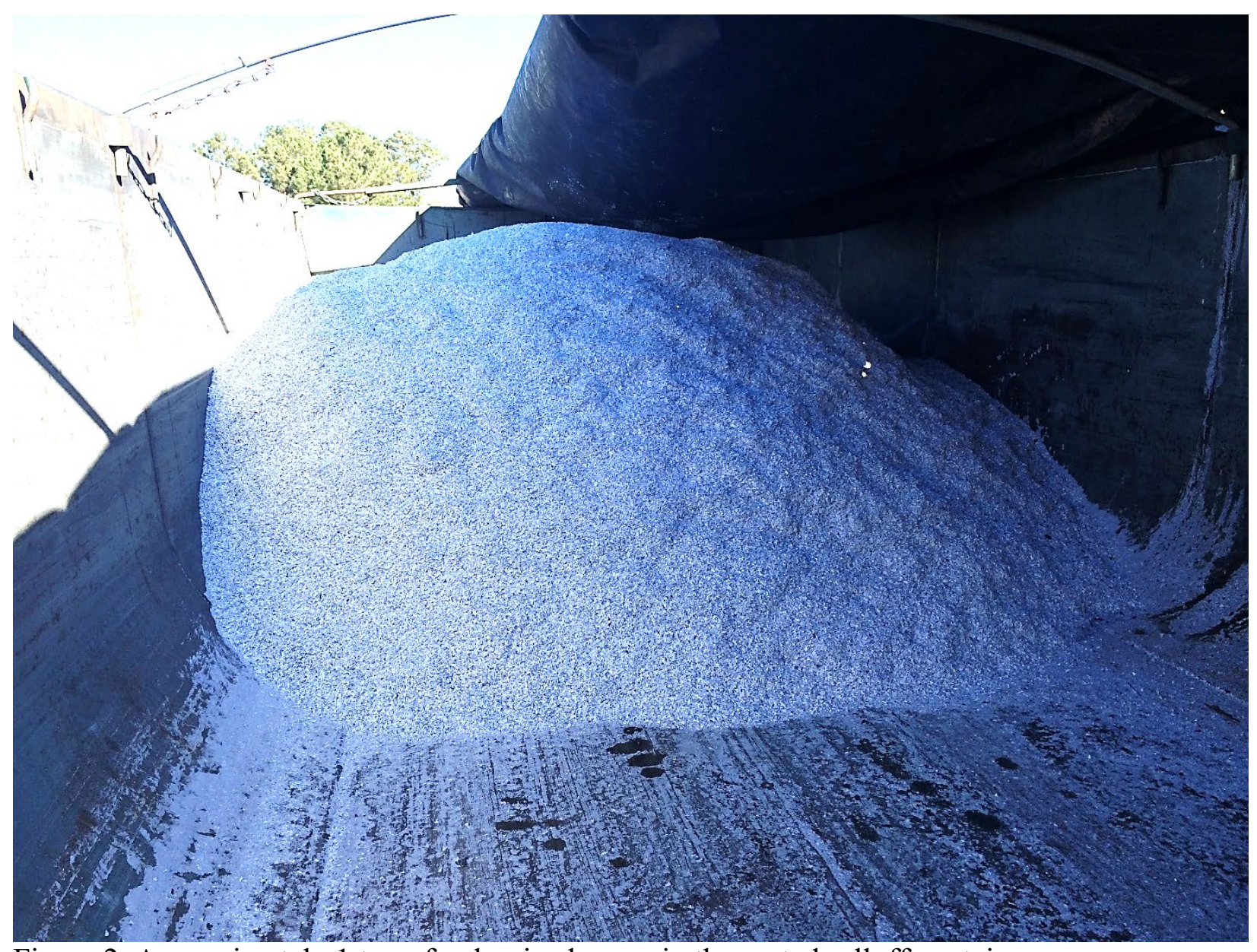

Figure 2. Approximately 1 ton of pulverized paper in the rented rolloff container. 


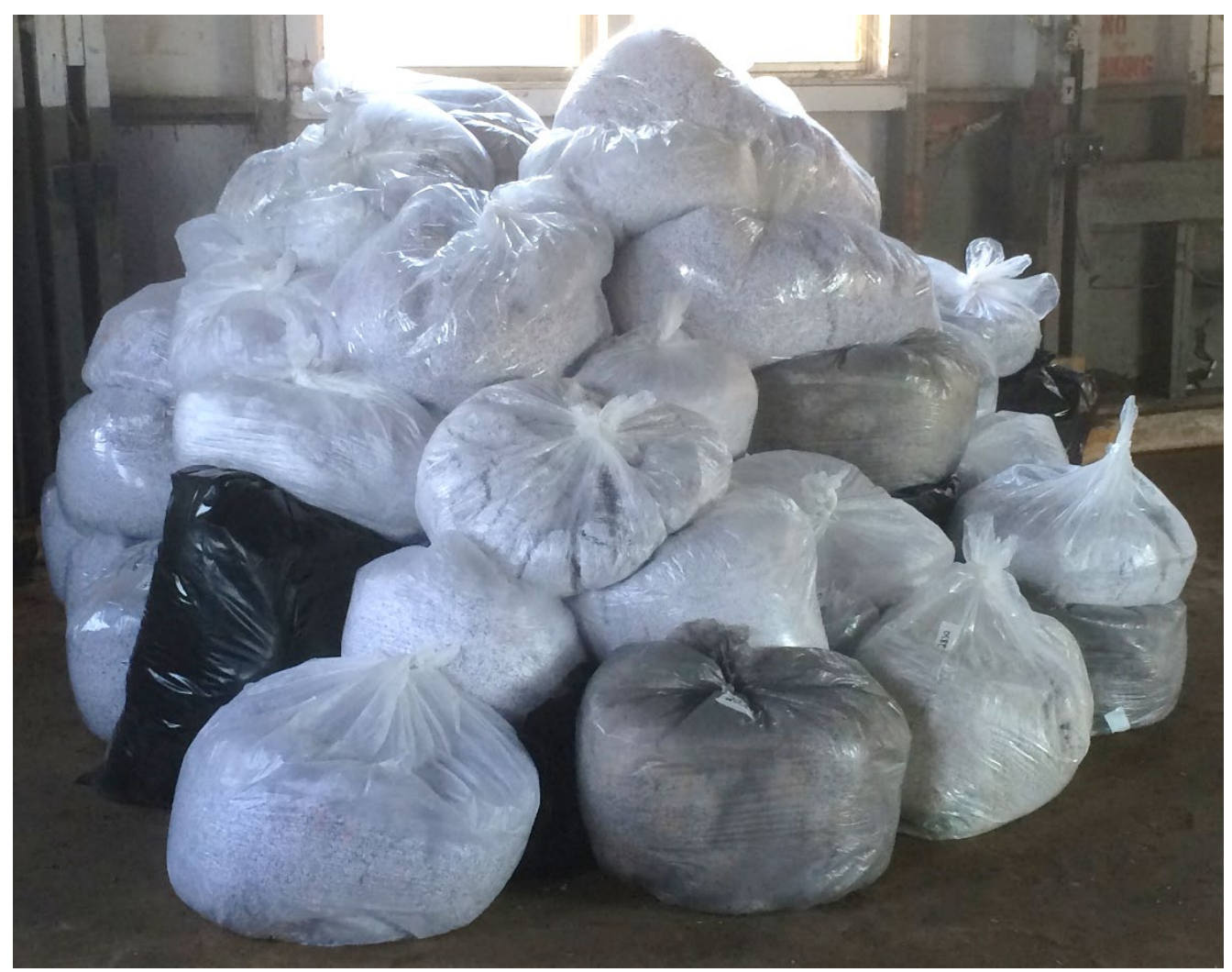

Figure 3. Batch-collected paper collected by a contractor. This batch was from multiple locations across Fort Polk and dropped off at the storage location.

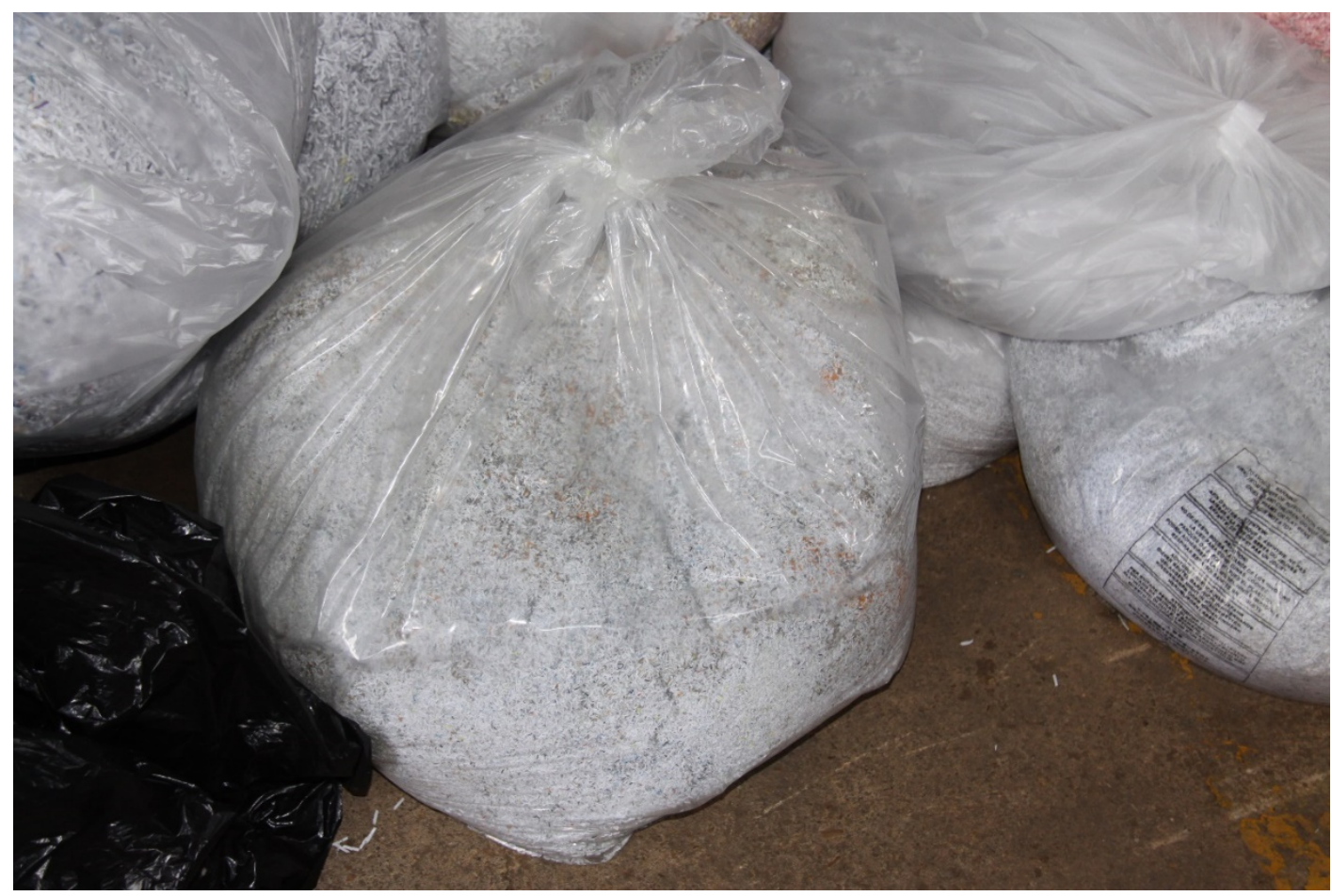

Figure 4. Close-up of a small batch-collected waste paper source. 


\section{Storage of Paper Material}

Initially, the plastic bags of pulverized paper were stored in an unused motorpool building that was awaiting demolition. Prior to demolition, the paper was moved to an unused forestry greenhouse. Paper stored in the rolloff container was bagged and placed with other paper stored in plastic bags. Because of the necessity for specific paper weights to be applied at the demonstration sites, storage in bags was necessary for accurate weighing and separation into different application rates. However, in circumstances where paper is to be applied in a similar manner, the requirement for storage in plastic bags is not necessary and is likely an impediment to efficient transportation and application to soils.

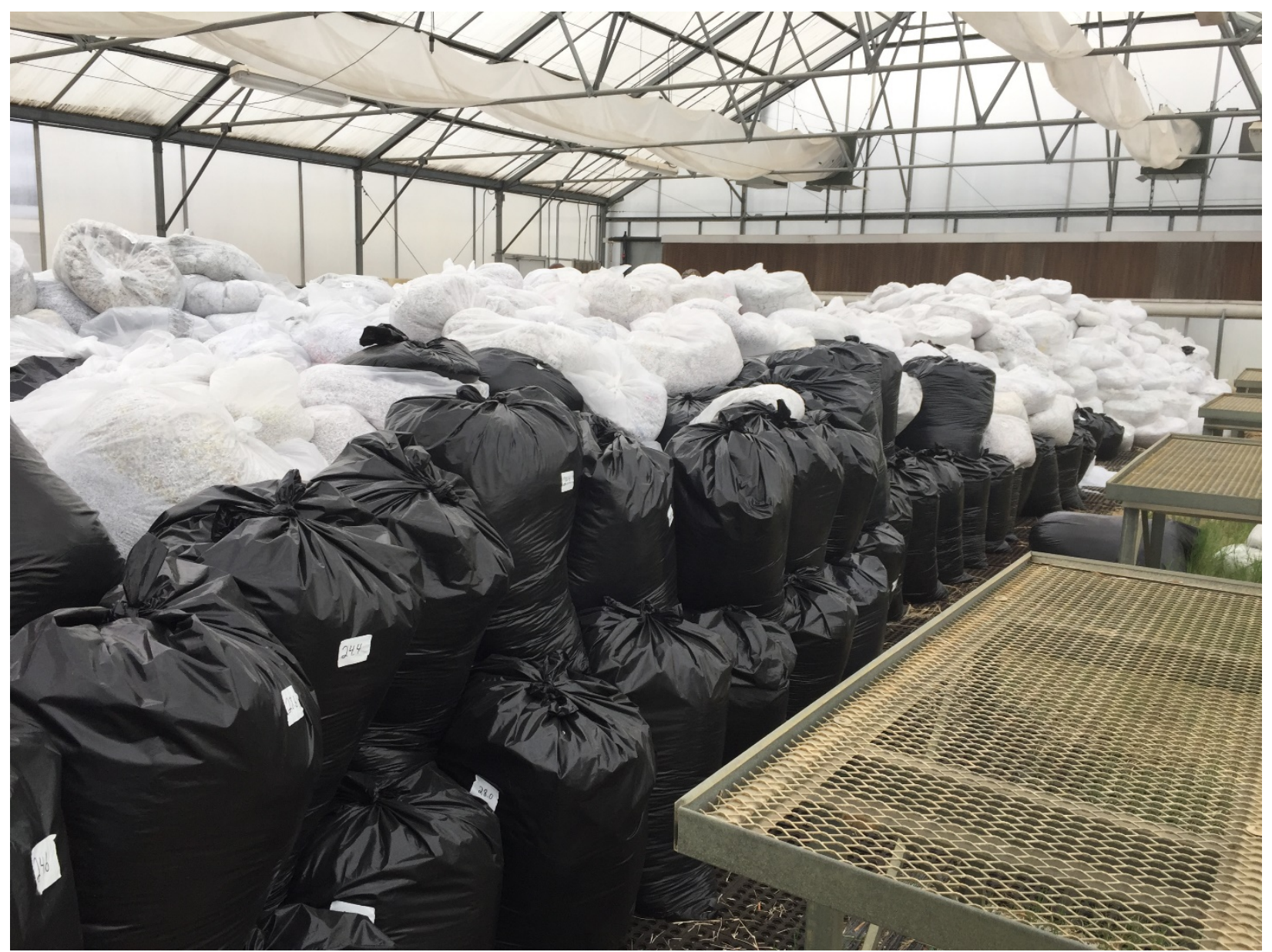

Figure 5. Bagged and weighed paper. Paper was stored in a greenhouse and awaiting transport to the field sites.

\section{Permitting for Land Application of Paper Material}

Approval for conducting this demonstration at Fort Polk, LA, was required at the state and installation levels. The Louisiana Department of Agriculture and Forestry issued a permit based on best management practices for application of the material to soil. Fort Polk issued approval based on completion of Records of Environmental Concern for each of the two demonstration sites. 


\section{Weighing of Paper Material}

To obtain exact application rates for the demonstration, all paper was bagged in plastic bags and weighed to allow for accurate placement on field plots. Bags were weighed with a benchtop 400 pound capacity postal scale, weights were recorded on a piece of duct tape placed on the bags, and all bag weights were recorded to document total cumulative mass of paper.

\subsection{ADVANTAGES AND LIMITATIONS OF THE TECHNOLOGY/METHODOLOGY}

Alternative technologies that exist for $\mathrm{N}$ immobilization are sucrose, sawdust, and other high $\mathrm{C}$ anthropogenic wastes. The advantages the proposed technology has over other technologies are availability, cost, and purity. Sucrose is the most pure high $\mathrm{C}$ source, but its cost makes it unfeasible for large-scale utilization. Sawdust can be contaminated or pure, but its primary limitations are availability and cost. Most high $\mathrm{C}$ anthropogenic wastes are available and inexpensive, but contamination is high. Pulverized paper is low in contaminants, widely available to the military, and associated costs are low. Major cost considerations are transportation to locations where it will be used and incorporation. However, because transportation costs are already incurred for removal, and current restoration activities already utilize mechanical devices to mix soil, this proposed technology can be repurposed for less than what current disposal and rehabilitation practices cost.

Limitations of the technology include the need to store the material in an enclosure that prevents wind transportation, as well as the requirement that application occur on more or less calm days. Volume availability also limits the applicability of the technology. The volumes produced by most installations will likely only allow annual treatment of a small area (likely in the range of 28 ha (5-20 ac)) of highly disturbed sites at the highest application rates. A larger area (likely in the range of 8-32 ha (20-80 ac)) can be treated at lower application rates. This demonstration/ validation will indicate what levels of change are observed across the range of application rates. This will allow end user utilization in the most effective manner given volume constraints. A further limitation is the seasonal effectiveness of the technology. To prevent offsite migration of the material, sites of application should be prepared by mechanical mixing of the soil. Frozen soil will prevent utilization in winter months. In climates where soil does not freeze, application of the material could be achieved during winter months, but decomposition of the material and nutrient immobilization could occur on a timescale that does not provide the greatest benefit to desirable native warm season perennial grasses if vegetation is not seeded and germinates soon after the material is applied. 


\subsection{PERFORMANCE OBJECTIVES}

\begin{tabular}{|c|c|c|c|}
\hline $\begin{array}{c}\text { Performance } \\
\text { Objective }\end{array}$ & Metric & Data Requirements & Success Criteria \\
\hline \multicolumn{4}{|c|}{ Quantitative Performance Objectives } \\
\hline $\begin{array}{l}\text { 1. Increased native } \\
\text { plant cover }\end{array}$ & $\begin{array}{l}\text { - Increased native plant } \\
\text { cover } \\
\text { - Decreased invasive } \\
\text { species cover }\end{array}$ & $\begin{array}{l}\text { - Plant composition and } \\
\text { cover measurements } \\
\text { - Comparisons between } \\
\text { application rate } \\
\text { treatments and controls } \\
\text { for each demonstration } \\
\text { site } \\
\text { - Comparisons between } \\
\text { application rate } \\
\text { treatments and standard } \\
\text { practice plots for each } \\
\text { demonstration site }\end{array}$ & 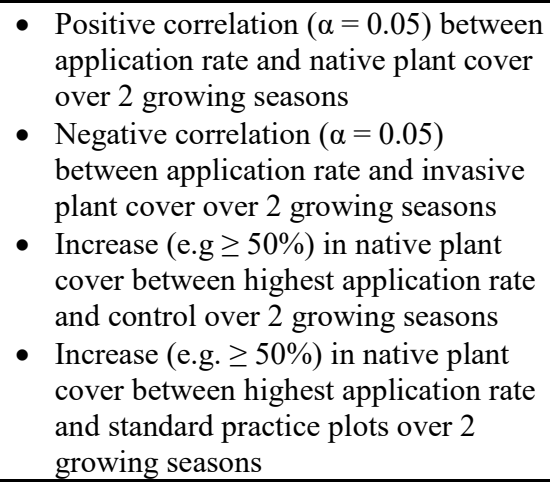 \\
\hline $\begin{array}{l}\text { 2. Increased native } \\
\text { plant biomass }\end{array}$ & $\begin{array}{l}\text { - Increased native plant } \\
\text { above-ground biomass } \\
\text { - Decreased invasive } \\
\text { species biomass }\end{array}$ & $\begin{array}{l}\text { - Plant biomass } \\
\text { measurements } \\
\text { - Comparisons between } \\
\text { application rate } \\
\text { treatments and controls } \\
\text { for each demonstration } \\
\text { site } \\
\text { - Comparisons between } \\
\text { application rate } \\
\text { treatments and standard } \\
\text { practice plots for each } \\
\text { demonstration site }\end{array}$ & $\begin{array}{l}\text { Positive correlation }(\alpha=0.05) \text { between } \\
\text { application rate and native plant } \\
\text { biomass over } 2 \text { growing seasons } \\
\text { - Negative correlation }(\alpha=0.05) \\
\text { between application rate and invasive } \\
\text { plant biomass over } 2 \text { growing seasons } \\
\text { - Increase }(\mathrm{e} . \mathrm{g} \geq 50 \%) \text { in native plant } \\
\text { biomass between highest application } \\
\text { rate and control over } 2 \text { growing } \\
\text { seasons } \\
\text { - Increase (e.g. } \geq 50 \%) \text { in native plant } \\
\text { biomass between highest application } \\
\text { rate and standard practice plots over } 2 \\
\text { growing seasons }\end{array}$ \\
\hline $\begin{array}{l}\text { 3. Increased plant } \\
\text { nutrient levels }\end{array}$ & $\begin{array}{l}\text { Increased chemical } \\
\text { composition of nutrients } \\
\text { in plant biomass }\end{array}$ & $\begin{array}{l}\text { Chemical analyses of plant } \\
\mathrm{Ca}, \mathrm{Fe}, \mathrm{K}, \mathrm{Mg}, \mathrm{Mn}, \mathrm{N}, \mathrm{P} \text {, } \\
\text { and } \mathrm{S} \text { concentrations for } \\
\text { each demonstration site }\end{array}$ & $\begin{array}{l}\text { Positive correlation }(\alpha=0.05) \text { between } \\
\text { application rate and plant nutrient } \\
\text { concentrations for deficient nutrients in } \\
\text { demonstration site soils over } 2 \text { growing } \\
\text { seasons. }\end{array}$ \\
\hline $\begin{array}{l}\text { 4. Improved soil } \\
\text { chemical properties }\end{array}$ & $\begin{array}{l}\text { Increased } \mathrm{C} \text { and } \\
\text { composition of deficient } \\
\text { nutrients in soils }\end{array}$ & $\begin{array}{l}\text { Chemical analyses of soil } \\
\text { total and organic } \mathrm{C} \text {, total } \mathrm{N} \text {, } \\
\text { and extractable } \mathrm{B}, \mathrm{Ca}, \mathrm{Cu} \text {, } \\
\mathrm{Fe}, \mathrm{K}, \mathrm{Mg}, \mathrm{Mn}, \mathrm{Mo}, \mathrm{Na}, \mathrm{P} \text {, } \\
\text { and } \mathrm{Zn} \text { concentrations for } \\
\text { each demonstration site }\end{array}$ & $\begin{array}{l}\text { - Positive correlation }(\alpha=0.05) \text { between } \\
\text { application rate and soil nutrient } \\
\text { concentrations for deficient nutrients in } \\
\text { demonstration site soils over } 2 \text { growing } \\
\text { seasons } \\
\text { - C:N ratio greater than } 30 \text { during the } \\
\text { first growing season, less than } 30 \\
\text { thereafter }\end{array}$ \\
\hline $\begin{array}{l}\text { 5. Improved soil } \\
\text { physical properties }\end{array}$ & $\begin{array}{l}\text { Decreased bulk density } \\
\text { and increased alkalinity }\end{array}$ & $\begin{array}{l}\text { Soil pH and bulk density } \\
\text { measurements for each } \\
\text { demonstration site }\end{array}$ & $\begin{array}{l}\text { - Positive correlation }(\alpha=0.05) \text { between } \\
\text { application rate and soil alkalinity over } \\
2 \text { growing seasons } \\
\text { - Negative correlation }(\alpha=0.05) \\
\text { between application rate and bulk } \\
\text { density over } 2 \text { growing seasons }\end{array}$ \\
\hline $\begin{array}{l}\text { 6. Low contaminant } \\
\text { loading }\end{array}$ & $\begin{array}{l}\text { Contamination due to } \\
\text { application }\end{array}$ & $\begin{array}{l}\text { Chemical analyses of } \mathrm{As}, \\
\mathrm{Cd}, \mathrm{Cr}, \mathrm{Cu}, \mathrm{Mo}, \mathrm{Ni}, \mathrm{Pb}, \mathrm{Sb}, \\
\mathrm{Se} \text {, and } \mathrm{Zn}(\mathrm{Hg} \text {, bisphenol } \\
\mathrm{A} \text {, and phthalates if } \\
\text { necessary) in soils for each } \\
\text { demonstration site }\end{array}$ & $\begin{array}{l}\text { Obtain metrics above without increasing } \\
\text { contaminant concentrations to greater than } \\
50 \% \text { of un-amended plot levels or above } \\
\text { EPA regulatory limits for land application } \\
\text { of waste materials over } 2 \text { growing seasons }\end{array}$ \\
\hline
\end{tabular}




\section{Increased native plant cover}

This metric will use a measure of vegetation quality to compare application rates to one another, as well as to the un-amended control and standard practice plots. This metric will demonstrate that the technology provides an acceptable level of desired vegetation cover. Performance will be measured during peak standing biomass for the first 2 growing seasons, to include the first year mineralization phase and the second year stabilization phase. Cover will be measured to calculate a per unit increase in native plant cover and a per unit decrease in invasive plant cover on a percent basis for the two demonstration sites individually.

Success will be determined through observation of a positive correlation $(\alpha=0.05)$ between application rates and native plant cover over 2 growing seasons, a negative correlation $(\alpha=0.05)$ between application rate and invasive plant cover over 2 growing seasons, and $a \geq 50 \%$ increase in native plant cover between the highest application rate and un-amended control and standard practice plots.

\section{Increased native plant biomass}

This metric will measure vegetation quantity to compare application rates to one another, as well as to the un-amended and standard practice control plots. This metric will demonstrate that the technology supports an acceptable level of desired vegetation biomass. Native plant biomass metrics will be evaluated by comparing native and invasive plant biomass across increasing application rates. Performance will be measured for the first 2 growing seasons by documenting the increase in native plant biomass across application rates to develop a per unit increase in native plant biomass on a $\mathrm{kg} \mathrm{m}^{-2}$ basis for the two demonstration sites. Success will be determined through observation of a positive correlation $(\alpha=0.05)$ between application rates and native plant biomass over 2 growing seasons, a negative correlation $(\alpha=0.05)$ between application rate and invasive plant biomass over 2 growing seasons, and a $\geq 50 \%$ increase in native plant biomass between the highest application rate and un-amended control and standard practice plots.

\section{Increased plant nutrition levels}

This metric will measure vegetation nutritive quality to compare application rates to one another, as well as to un-amended control and standard practice plots. This metric will demonstrate that the technology supports adequate nutrient availability for plant uptake. Nutrient content will be determined by collecting a composite subsample from each biomass sample. Plant nutrition metrics will be evaluated by comparing concentrations of nutrients in plant biomass across application rates. Performance will be measured for the first two growing seasons by documenting the increase in plant nutrient concentrations across application rates to develop a per unit increase in nutrient concentrations on a mg kg${ }^{-1}$ basis for the two demonstration sites. Success will be determined through observation of a positive correlation $(\alpha=0.05)$ between application rates and plant nutrient concentrations for deficient nutrients (Table 3 ). 


\section{Improved soil chemical properties}

This metric will measure soil chemical property changes across application rates and controls to demonstrate that the technology improves soil nutrient levels. Soil chemical property metrics will be evaluated by comparing concentrations of nutrients in soils across increasing application rates. Performance will be measured for the first two growing seasons by documenting the increase in soil nutrient concentrations across application rates to develop a per unit increase in nutrient concentrations on a $\mathrm{mg} \mathrm{kg}^{-1}$ basis for the two demonstration sites. Success will be determined through observation of a positive correlation $(\alpha=0.05)$ in soil $\mathrm{C}$ and deficient soil nutrients (Table 3) between application rate and nutrient concentration, and a $\mathrm{C}: \mathrm{N}$ ratio greater than 30 in the first growing season and less than 30 in the second growing season.

\begin{tabular}{|ccc|}
\hline \multicolumn{3}{|c|}{ Table 3. Normal ranges of plant nutrients in native grasses and soils ${ }^{1}$. } \\
\hline \multicolumn{3}{|c|}{} \\
\hline Nutrient & Grass Concentration (\%) & Soil Concentration (\%) \\
$\mathrm{N}$ & $0.25-2$ & $<0.2$ \\
$\mathrm{P}$ & $0.1-0.3$ & $0.1-0.3$ \\
$\mathrm{~K}$ & $1-4$ & $0.5-5$ \\
$\mathrm{Ca}$ & $0.2-0.5$ & $0.1-5$ \\
$\mathrm{Mg}$ & $0.1-0.5$ & $0.5-2$ \\
$\mathrm{~S}$ & $0.1-1$ & $0.01-0.05$ \\
$\mathrm{Mn}$ & $0.001-0.01$ & $0.01-0.1$ \\
$\mathrm{~B}$ & $.005-0.03$ & $0.02-0.07$ \\
$\mathrm{Mo}$ & $0.0002-0.002$ & $0.0005-0.02$ \\
$\mathrm{Fe}$ & $0.004-0.02$ & $0.5-10$ \\
$\mathrm{Cu}$ & $0.0003-0.003$ & $0.0003-0.005$ \\
$\mathrm{Zn}$ & $0.001-0.05$ & $0.001-0.03$ \\
\hline${ }^{1}$ From Munshower (1994) and Kabata-Pendias and Pendias (2001). \\
\hline \multicolumn{3}{|}{}
\end{tabular}

\section{Improved soil physical properties}

This metric will measure soil physical property changes across application rates and controls to demonstrate that the technology improves soil physical properties. Soil physical property metrics will be evaluated by comparing changes in bulk density and $\mathrm{pH}$ in soils across increasing application rates. Performance will be measured for the first two growing seasons by documenting the decrease in bulk density and movement toward neutral $\mathrm{pH}$ in soils across application rates to develop a per unit change in bulk density (on a $\mathrm{g} \mathrm{cm}^{-3}$ basis) and $\mathrm{pH}$ for the two demonstration sites. Success will be determined through observation of a positive correlation $(\alpha=0.05)$ between application rate and soil alkalinity and a negative correlation $(\alpha=0.05)$ between application rate and bulk density over 2 growing seasons. 


\section{Low contaminant loading}

One of the focal points of this demonstration/validation is to demonstrate the benign nature of this material. A thorough chemical analysis will be conducted on the material prior to implementation of the demonstration/validation sites and compared to previous analyses for this material. Additionally, minor components of the material (compact discs and mylar film) will be quantified through standard sucrose density gradient separation techniques. Analyses will include characterization of contaminants of concern, including $\mathrm{As}, \mathrm{Cd}, \mathrm{Cr}, \mathrm{Cu}, \mathrm{Hg}, \mathrm{Mo}, \mathrm{Ni}, \mathrm{Pb}$, $\mathrm{Sb}, \mathrm{Se}, \mathrm{Zn}$, bisphenol A, and phthalates. Copper, Mo, and $\mathrm{Zn}$ will be obtained for Improve soil chemical properties metric, and $\mathrm{As}, \mathrm{Cd}, \mathrm{Cr}, \mathrm{Ni}, \mathrm{Pb}$, and $\mathrm{Se}$ will be collected as additional contaminants of concern. Based on the characterization of the paper, $\mathrm{Hg}, \mathrm{Sb}$, bisphenol A, and phthalates will also be analyzed if necessary based on initial characterization of the pulverized paper.

Performance will be measured for the first 2 growing seasons by comparing contaminant concentrations in the paper material to EPA regulations to calculate maximum loading limits. Further contaminant loading metric evaluation will be conducted by comparing changes to contaminant concentrations at different application rates to the un-amended control plots in demonstration/validation site soils. Success will be determined by obtaining the above metrics without increasing any regulated contaminant concentrations to greater than $50 \%$ of control soil levels or above regulatory limits. 


\subsection{SITE DESCRIPTION}

\subsection{SITE LOCATION AND HISTORY}

Two sites were selected in year 1 that encompassed the following characteristics: one is located on an Alfisol, one is located on an Ultisol; 0.4 hectare ( 1 acre) each in size; neither with a recent history of heavy and repeated disturbances; neither contaminated with compounds regulated for land application of waste; neither with a visible population of highly aggressive invasive plant species; easily accessible with equipment required for demonstration and evaluation of technology; slope less than 5\%; has not been burned by wildfire in the past 5 years; not occurring in a floodplain; uniform existing vegetation; and approved by Fort Polk installation land managers.

The Army Net Zero Waste Initiative seeks to reuse and re-purpose waste (DoD, 2012), and Fort Polk, LA is a pilot net-zero waste installation (DoD, 2011a). Fort Polk also operates an on-site document cross-cut shredder that produces 5.5 to 7.5 cubic meters per week, which can provide sufficient quantities of material to sponsor a field demonstration. Fort Polk is also comprised primarily of the 2 most commonly occurring soil orders on CONUS military installations (Alfisols and Ultisols), allowing a demonstration of the technology for both of these soil types at 1 installation.

\subsection{SITE CHARACTERISTICS}

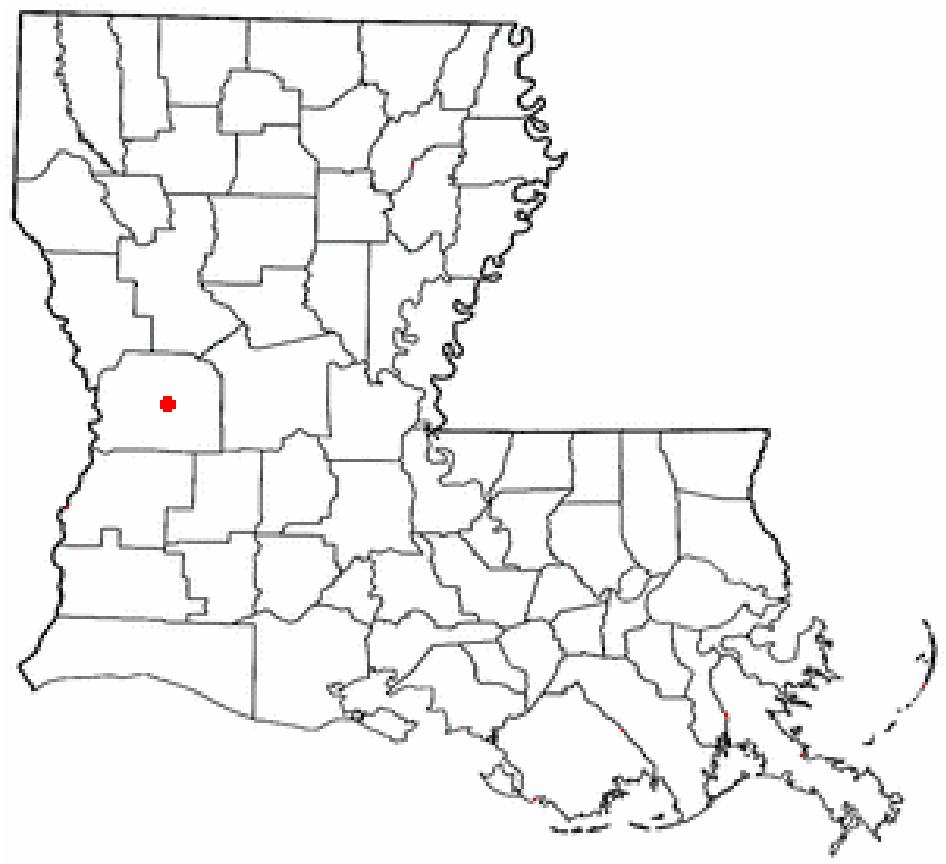

Figure 6. Location of Fort Polk in Louisiana.

Fort Polk, LA, is located approximately $320 \mathrm{~km}$ (200 miles) northeast of Houston, TX (Figure 6). Fort Polk is home to the Joint Readiness Training Center, and encompasses 80,500 ha (198,700 acres), of which 39,700 ha (98,000 acres) is leased by Kisatchie National Forest. Fort 
Polk is situated in the Outer Coastal Plain Mixed Forest Province (Bailey, 1995) and the Southern Mixed Forest (Kuchler, 2000). Most of the sandy soils (Ultisols) are dominated by longleaf pine and flatwoods vegetation. The fine-textured soils (Alfisols) historically supported hardwood forests. Soils at Fort Polk are primarily sands with fine-textured soils in the floodplains, although the north areas of the installation are comprised of fine-textured upland soils (Figure 7). All silt loams and loams are alfisols ( $41.0 \%$ of Fort Polk), while $97.2 \%$ of sands and $73.6 \%$ of sandy loams are ultisols (57.1\% of Fort Polk) (Figure 7, Table 4$)$.

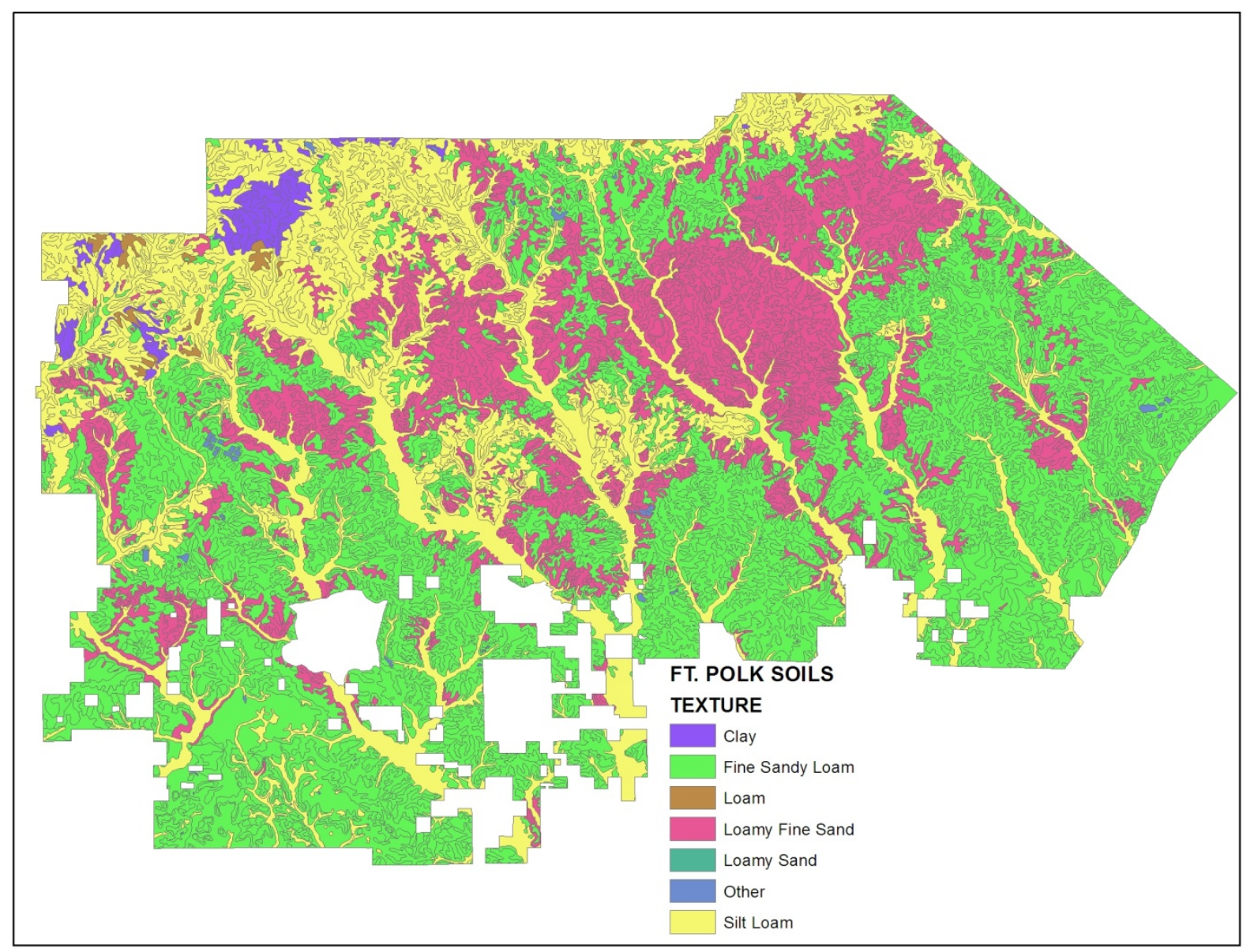

Figure 7. Soil texture map of Fort Polk. 


\begin{tabular}{|c|c|c|c|c|}
\hline Soil & $\underline{\text { Soil }}$ & $\frac{\text { Area }}{\text { (Acres) }}$ & $\stackrel{\text { Area }}{\text { (Hectares) }}$ & $\frac{\text { Total Area of }}{\text { Fort Polk (\%) }}$ \\
\hline Betis loamy fine sand, $1-5 \%$ slopes & Ultisol & 2335.6 & 945.9 & 2.3 \\
\hline Betis loamy fine sand, 5-12 \% slopes & Ultisol & 4511.1 & 1827.0 & 4.4 \\
\hline Boykin loamy fine sand, $1-3 \%$ slopes & Ultiosl & 75.4 & 30.5 & 0.1 \\
\hline Boykin loamy fine sand, 3-8 \% slopes & Ultisol & 177.6 & 71.9 & 0.2 \\
\hline Briley loamy fine sand, $1-5 \%$ slopes & Ultisol & 10672.8 & 4322.5 & 10.3 \\
\hline Briley loamy fine sand, 5-12\% slopes & Ultisol & 10976.8 & 4445.6 & 10.6 \\
\hline Osier loamy fine sand, $0-2 \%$ slopes & Entisol & 807.8 & 327.2 & 0.8 \\
\hline Total Loamy Fine Sands & & 29557.1 & 11970.6 & 28.6 \\
\hline Caddo silt loam, 0-1 \% slopes & Alfisol & 37.7 & 15.3 & 0.0 \\
\hline Eastwood silt loam, 1-5 \% slopes & Alfisol & 5360.6 & 2171.0 & 5.2 \\
\hline Eastwood silt loam, 5-12 \% slopes & Alfisol & 15920.4 & 6447.8 & 15.4 \\
\hline Guyton silt loam, occasionally flooded & Alfisol & 25.3 & 10.2 & 0.0 \\
\hline Silt Loams & & 21344.0 & 8644.3 & 20.6 \\
\hline \multicolumn{5}{|l|}{ Beauregard fine sandy loam, 1-3 \% } \\
\hline slopes & Ultisol & 1023.3 & 414.4 & 1.0 \\
\hline Cahaba fine sandy loam, 1-3\% slopes & Ultisol & 995.5 & 403.2 & 1.0 \\
\hline \multicolumn{5}{|l|}{ Kisatchie-Rayburn fine sandy loams, 5- } \\
\hline $20 \%$ slopes & Alfisol & 22.5 & 9.1 & 0.0 \\
\hline Malbis fine sandy loam, 1-3\% slopes & Alfisol & 5252.4 & 2127.2 & 5.1 \\
\hline Malbis fine sandy loam, 3-5\% slopes & Alfisol & 5330.2 & 2158.7 & 5.2 \\
\hline Ruston fine sandy loam, 1-3\% slopes & Ultisol & 10469.9 & 4240.3 & 10.1 \\
\hline Ruston fine sandy loam, 3-8\% slopes & Ultisol & 15514.5 & 6283.4 & 15.0 \\
\hline Sacul fine sandy loam, 1-5\% slopes & Ultisol & 25.4 & 10.3 & 0.0 \\
\hline Sawyer very fine sandy loam, 1-5 \% & Ultisol & & & \\
\hline slopes & & 882.0 & 357.2 & 0.9 \\
\hline Total Fine Sandy Loams & & 39515.7 & 16003.9 & 38.2 \\
\hline \multicolumn{5}{|l|}{ Guyton-Luka complex, frequently } \\
\hline flooded & Alfisol & 9878.2 & 4000.7 & 9.6 \\
\hline Hornbeck clay, $1-5 \%$ slopes & Vertisol & 1195.5 & 484.2 & 1.2 \\
\hline Hornbeck clay, 5-8 \% slopes & Vertisol & 878.2 & 355.7 & 0.8 \\
\hline Kirbyville-Niwana complex & Ultisol & 276.3 & 111.9 & 0.3 \\
\hline Vaiden loam, 1-5 \% slopes & Alfisol & 512.0 & 207.4 & 0.5 \\
\hline Pits & & 66.4 & 26.9 & 0.1 \\
\hline Water & & 161.9 & 65.6 & 0.2 \\
\hline Total Other Soils and Features & & 12968.5 & 5252.2 & 12.5 \\
\hline Total & & 103385.30 & 41871.0 & 100.0 \\
\hline
\end{tabular}




\subsection{TEST DESIGN}

\subsection{CONCEPTUAL TEST DESIGN}

The test design included 2 sites, divided into 4 blocks each, and plots $10 \mathrm{~m} \mathrm{X} 10 \mathrm{~m}$ placed in a randomized complete block design (Figure 8). Each block consisted of 4 application rates of pulverized paper. The first site received paper application rates of $17.9,35.9,53.8$, and $71.7 \mathrm{Mg}$ $\mathrm{ha}^{-1}\left(8,16,24\right.$, and 32 tons $\left.\mathrm{ac}^{-1}\right)$, based on previous studies showing positive responses on vegetation up to $143 \mathrm{Mg} \mathrm{ha}^{-1}$ (64 tons ac ${ }^{-1}$ ) (Busby et al. 2006). Due to the difficulty in incorporating the highest 2 application rates into soil, rates were cut in half at the second site (Table 5).

\begin{tabular}{|c|c|c|c|}
\hline \multicolumn{4}{|c|}{$\begin{array}{l}\text { Table 5. Paper application } \\
\text { two demonstration sites. }\end{array}$} \\
\hline \multicolumn{4}{|c|}{$\begin{aligned} \text { Site } \\
\end{aligned}$} \\
\hline \multicolumn{2}{|c|}{ Briley } & \multicolumn{2}{|c|}{ Eastwood } \\
\hline$\underline{\mathrm{Mg} \mathrm{ha}^{-1}}$ & tons $\mathrm{ac}^{-1}$ & $\underline{\mathrm{Mgha}^{-1}}$ & tons $\mathrm{ac}^{-1}$ \\
\hline 17.9 & 8 & 9 & 4 \\
\hline 35.9 & 16 & 17.9 & 8 \\
\hline 53.8 & 24 & 26.9 & 12 \\
\hline 71.7 & 32 & 35.9 & 16 \\
\hline
\end{tabular}

However, half of that upper limit provides significant benefits (Blumenthal et al. 2003; Busby et al. 2006) while also incorporating into the upper soil horizons easily. Blocks also each contained an un-amended control plot (disked and seeded only) and a plot prepared using standard land rehabilitation practices (lime and fertilizer based on characterization of the sites). These application rates achieved a desired range of recommended rates for utilization of cellulosic waste material and provided for a validation of the technology in a cost-effective manner. 


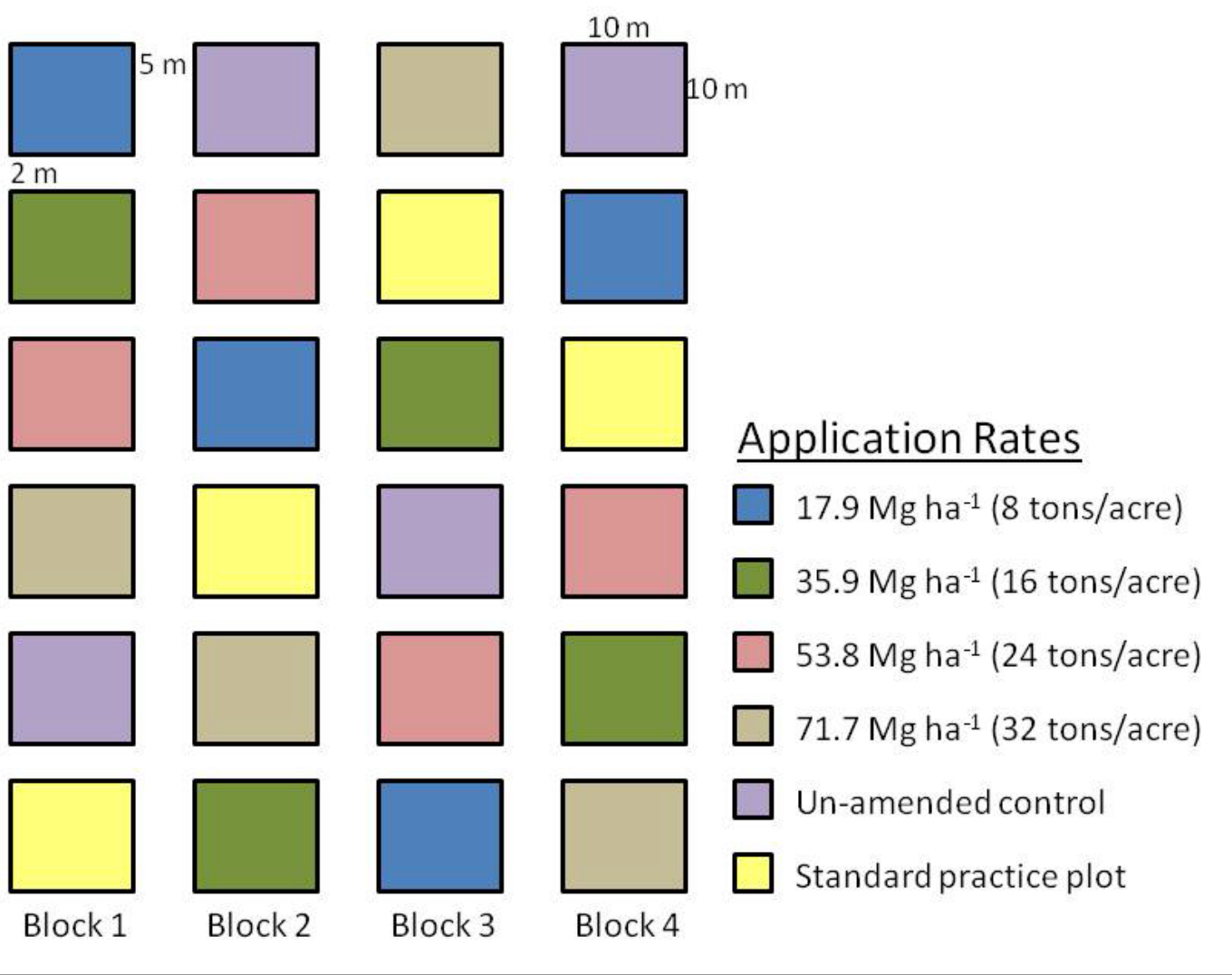

Figure 8. Diagram of plot layout at demonstration sites. Plots are $10 \mathrm{~m} \mathrm{X} 10 \mathrm{~m}$ with $2 \mathrm{~m}$ between plots, placed in a randomized complete block design with 4 blocks spaced $5 \mathrm{~m}$ apart. Application rates for the paper were halved at the second site but followed the same design. Six application rates were demonstrated and evaluated, including an un-amended control plot that is only disked and seeded, and a standard practice control plot that is amended with lime and fertilizer at rates calculated from initial baseline chemical analyses of demonstration sites.

\subsection{BASELINE CHARACTERIZATION AND PREPARATION}

Baseline characterization of the pulverized paper material included chemical analyses for concentrations of As, $\mathrm{Cd}, \mathrm{Cr}, \mathrm{Cu}, \mathrm{Hg}, \mathrm{Mo}, \mathrm{Ni}, \mathrm{Pb}, \mathrm{Sb}, \mathrm{Se}, \mathrm{Zn}$, bisphenol A, and phthalates. These contaminants included all contaminants regulated by the EPA for waste application, as well as potential contaminants based on the waste stream. Additionally, paper was analyzed for agronomic properties: total $\mathrm{C}$ and $\mathrm{N}$ and extractable $\mathrm{P}, \mathrm{K}, \mathrm{Ca}, \mathrm{Fe}, \mathrm{Mg}, \mathrm{Mn}$, and $\mathrm{S}$. Non-paper contaminants were measured using a sucrose density gradient to determine the prevalence and quantity of polycarbonate (DVDs) and polyethylene terephthalate (mylar films) in the paper material.

At each demonstration/validation site, 25 soil cores to a depth of $30 \mathrm{~cm}$ (12 inches) were collected in a grid (Figure 9). Baseline characterization of sites included background chemical characterization of levels of $\mathrm{As}, \mathrm{Cd}, \mathrm{Cr}, \mathrm{Cu}, \mathrm{Mo}, \mathrm{Ni}, \mathrm{Pb}, \mathrm{Se}, \mathrm{Zn}$; total $\mathrm{C}$ and $\mathrm{N}$; extractable $\mathrm{P}, \mathrm{K}$, $\mathrm{Ca}, \mathrm{Fe}, \mathrm{Mg}, \mathrm{Mn}$, and $\mathrm{S}$; and $\mathrm{pH}$ and bulk density. Due to expenses associated with testing for $\mathrm{Hg}$, 
$\mathrm{Sb}$, bisphenol A, and phthalates, characterizing these contaminants in the field soils was not conducted as their presence was not detected in the characterized paper samples at a level that warranted monitoring throughout the demonstration phase. Baseline characterization was only used to establish variation gradients for soil chemicals and identify potential contaminated areas. Because no significant variations were identified at either demonstration site, these data were not presented nor utilized in determining blocking or plot placement.

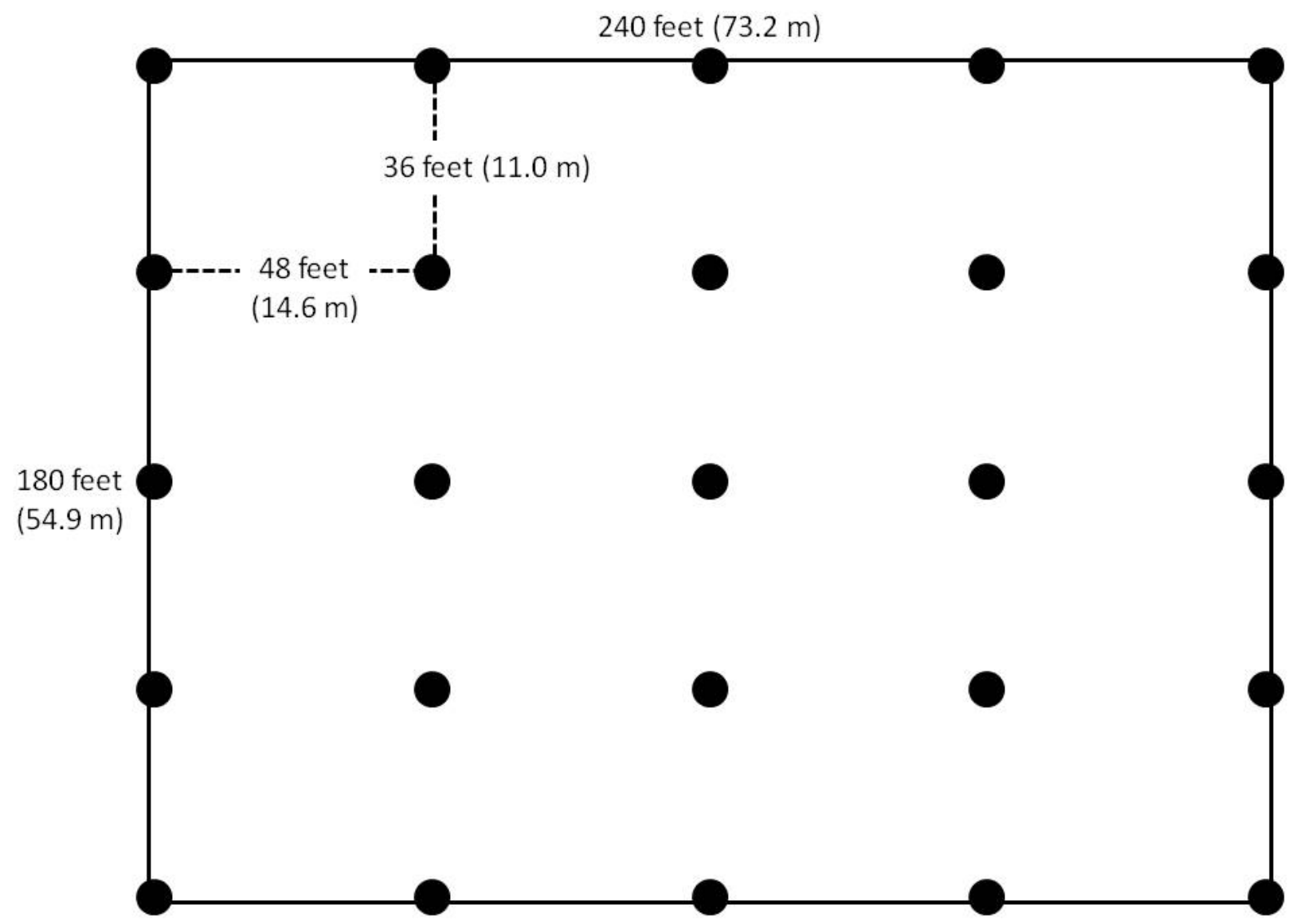

Figure 9. Sampling grid design for characterizing soils at field sites.

\subsection{DESIGN AND LAYOUT OF TECHNOLOGY AND METHODOLOGY COMPONENTS}

\section{Material collection}

Pulverized paper material was collected from the Fort Polk shredding facility and from various other source locations across the post, and stored in an unused building and roll-off container(s) until the desired quantity was obtained $(22,000 \mathrm{~kg}=24$ tons). A rental moving truck was used to transport the bagged paper material to the demonstration/validation sites. 


\section{Site preparation}

Demonstration/validation sites were prepared by disking sites. Paper was weighed and placed on plots at appropriate application rates (Figure 8), and spread uniformly over the plots by raking. Lime was added to standard practice control plots to achieve a $\mathrm{pH}$ of 6.5 (1 ton per acre rate), and $\mathrm{N}$ was added in the form of urea to supply $56 \mathrm{~kg} \mathrm{~N}$ per hectare $(50 \mathrm{lb}$ per acre). Plots were then disked again to incorporate paper material into the top $15 \mathrm{~cm}$ (6 inches) of soil. All plots were seeded in April of 2015 with native warm season grasses: big bluestem (Andropogon gerardii), 16.8 PLS kg ha ${ }^{-1}$ (15 PLS lb ac ${ }^{-1}$ ), indiangrass (Sorghastrum nutans), 16.8 PLS kg ha(15 PLS lb ac${ }^{-1}$ ), little bluestem (Schizachyrium scoparium), 16.8 PLS kg ha $^{-1}$ (15 PLS lb ac ${ }^{-1}$ ); and switchgrass (Panicum virgatum), 5.6 PLS kg ha ${ }^{-1}$ (5 PLS lb ac ${ }^{-1}$ ).

\subsection{FIELD TESTING}

\section{Site Selection and Characterization}

Field testing was performed on the 2 most common soil orders found on military training lands: an alfisol and ultisol, hereafter referred to as the Eastwood and Briley sites, respectively (corresponding to soil type names at each site). Characterization of the sites confirmed no prior issues and indicated that baseline soil properties were consistent across each site. Paper characterization indicated that no contaminant concerns existed with regards to land application. On each soil type, an area 0.4 hectare ( 1 acre) in size ( 240 X 180 feet) was selected that did not have a recent history of fires or heavy training disturbance.

\section{Field Demonstration Design and Implementation}

Beginning in summer 2014, pulverized paper from Fort Polk's document shredding facility was collected and stored in a building and roll-off container (Figures 2-5, 10). Paper placed into contractor garbage bags and weighed were transported to each site. Sites were disked and flagged to create 4 blocks with 6 plots each (Figures 11-12). Bagged paper was placed onto each plot until the desired application rate was achieved (Figure 13). Paper was then spread over the plot (Figure 14) and raked to ensure even coverage (Figure 15). Standard practice plots received pre-determined rates of lime and fertilizer based on soil testing. Immediately following spreading and standard practice plot amendment addition, a final disking of the entire site was used to mix the paper and amendments into the top $15 \mathrm{~cm}$ (6 inches) of soil (Figures 16-17). Once paper was incorporated, native grass seed was hand applied and the site was dragged with a utility vehicle pulling a weighted cattle panel to improve seed/soil contact. 


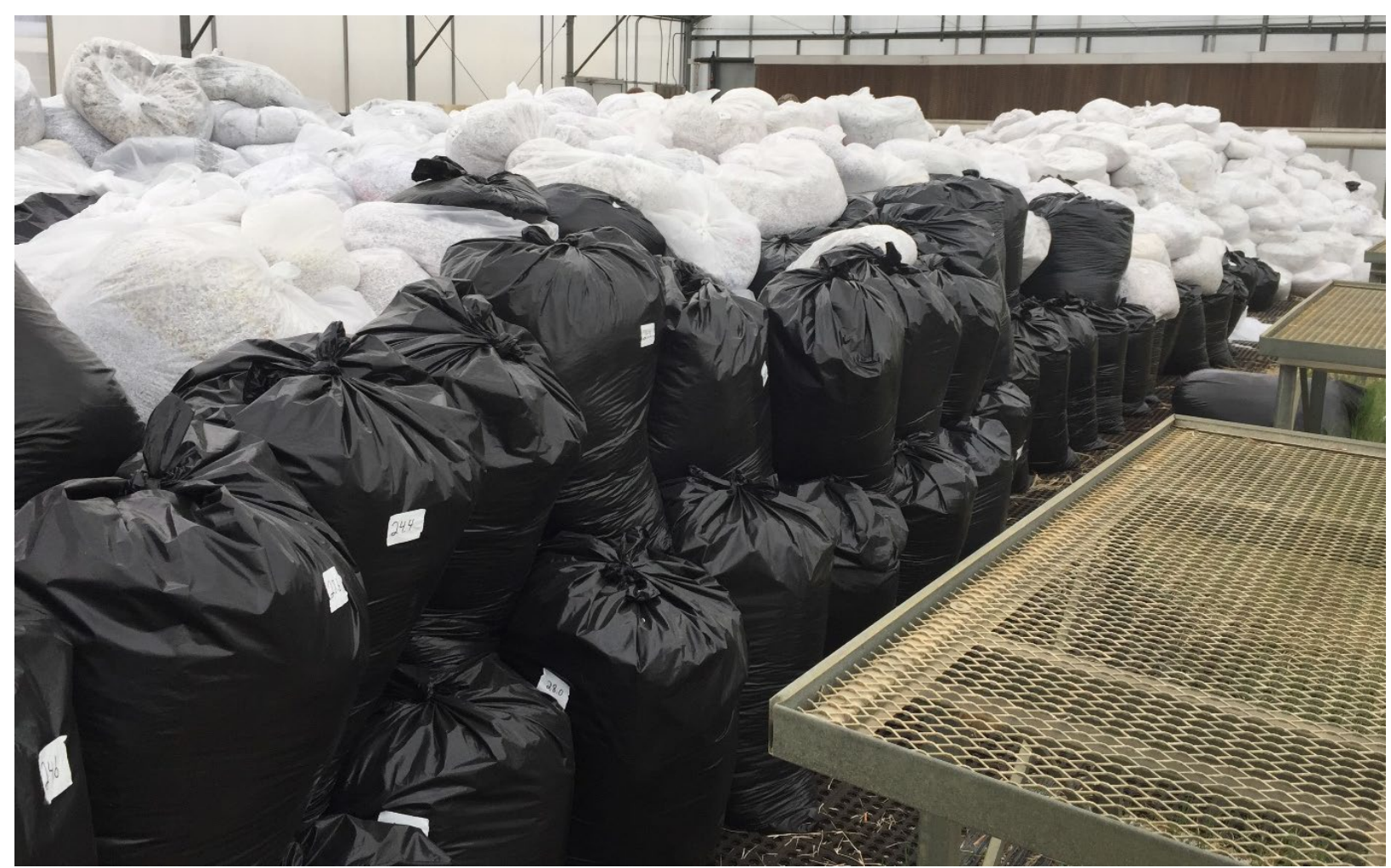

Figure 10. Bagged and weighed paper awaiting transport to demonstration sites.

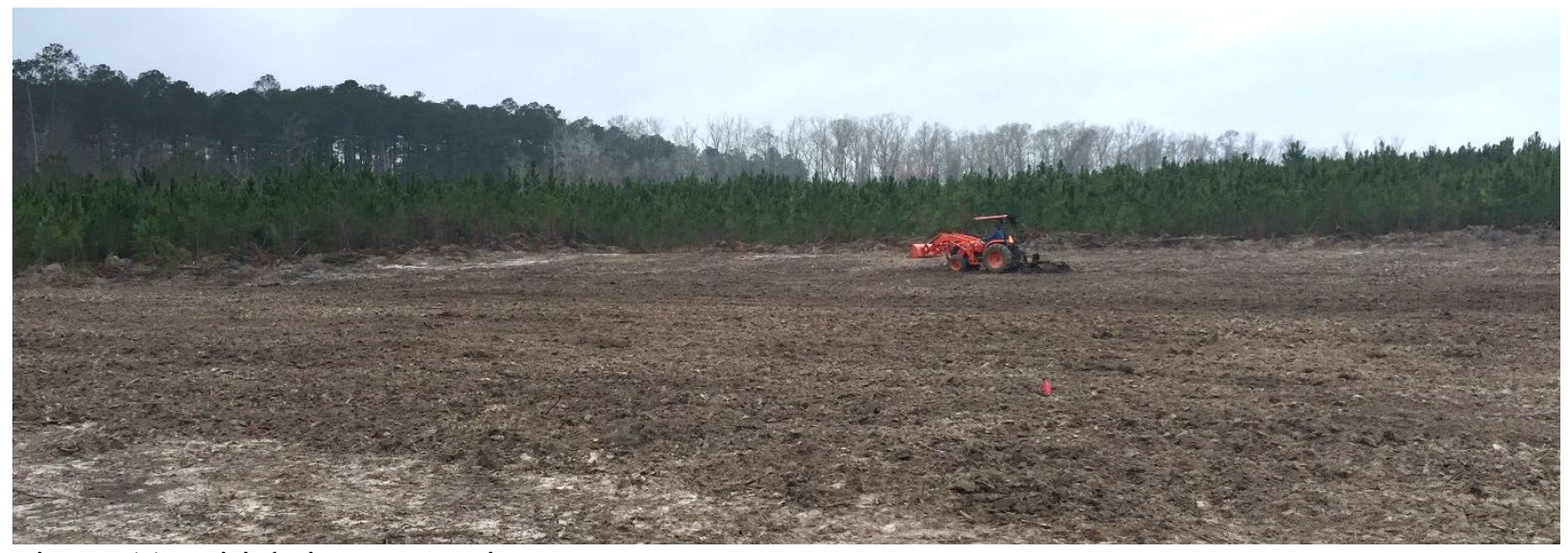

Figure 11. Initial site preparation. 


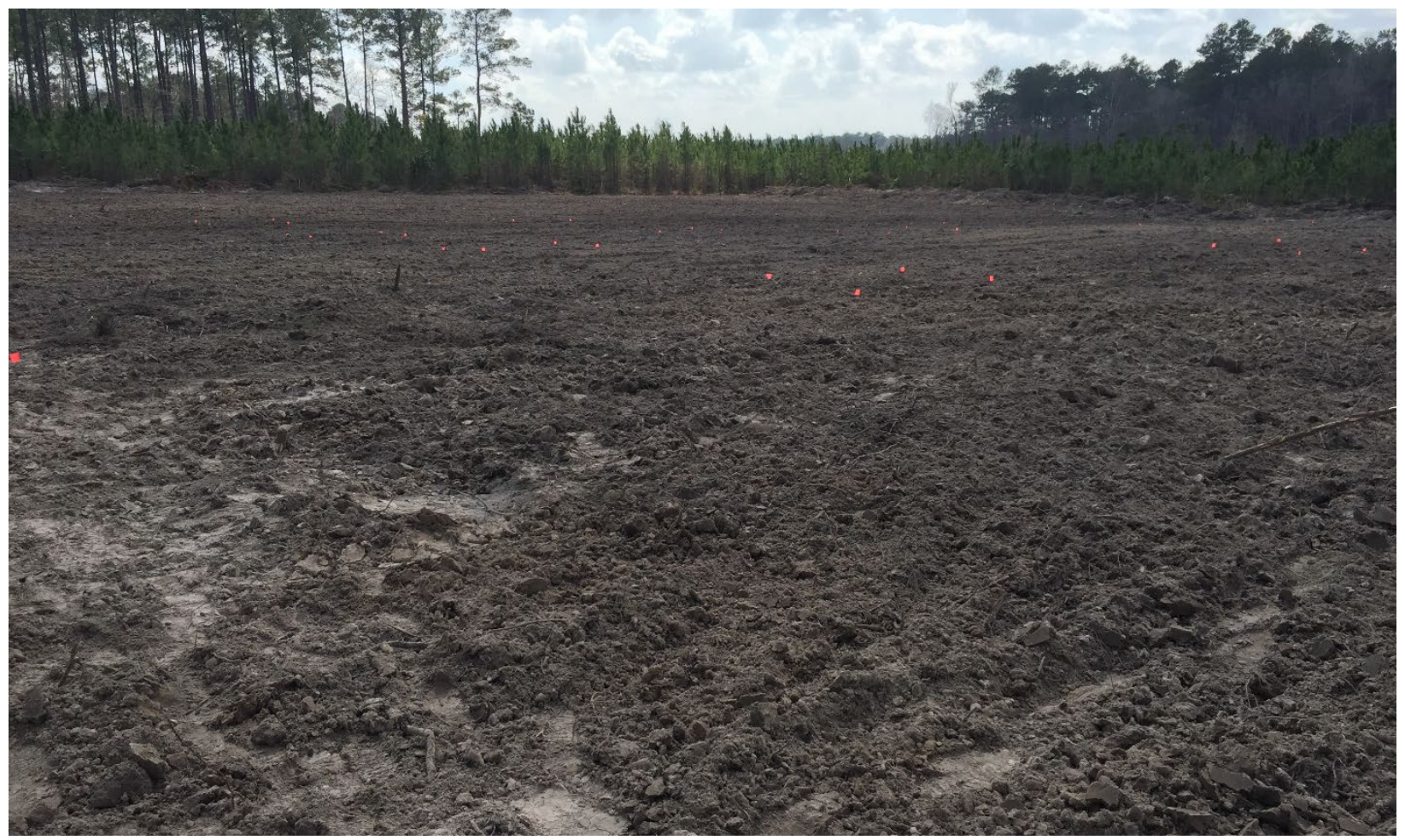

Figure 12. Prepared site with plots flagged.

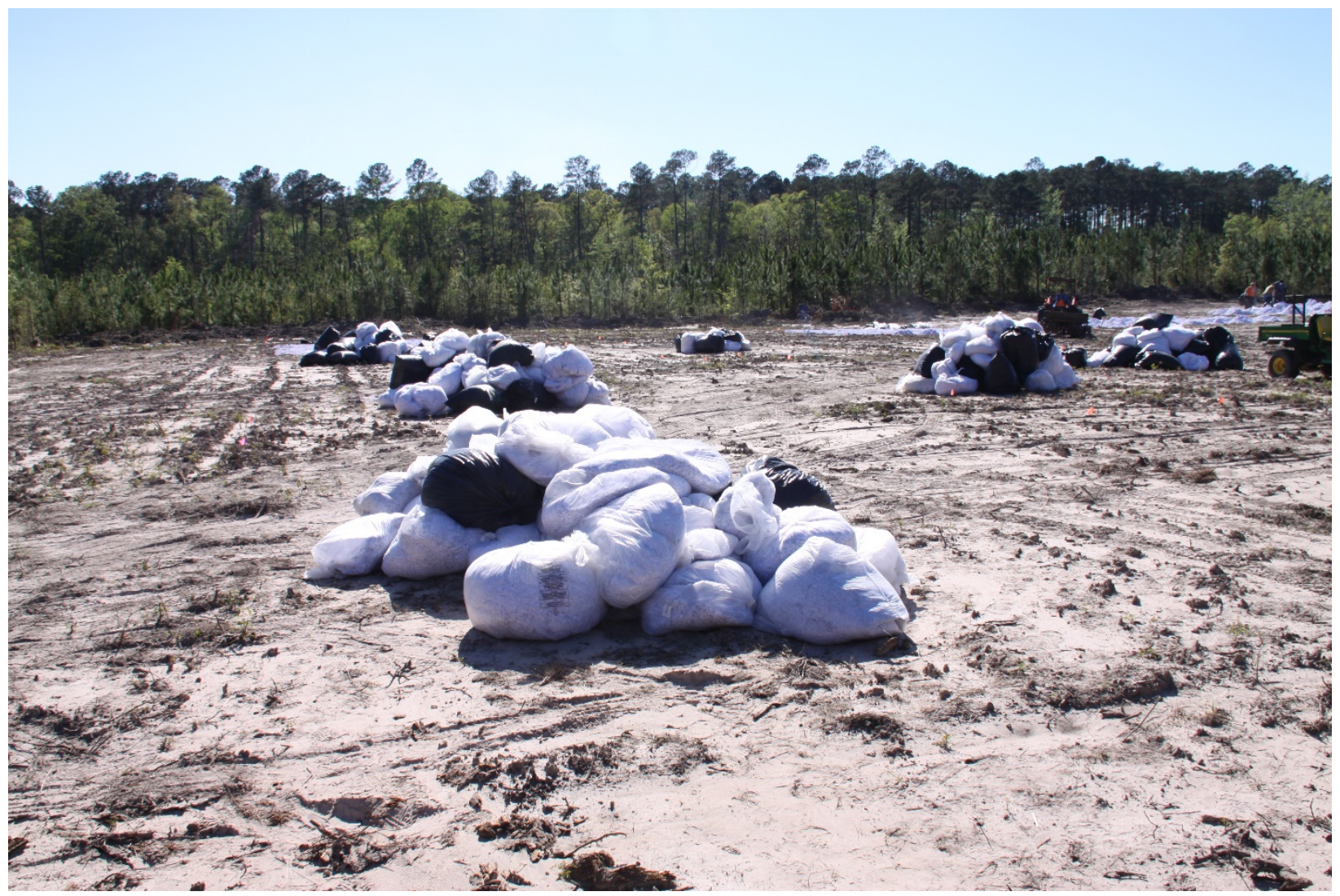

Figure 13. Weighed paper placed into respective plots to achieve desired application rates. 


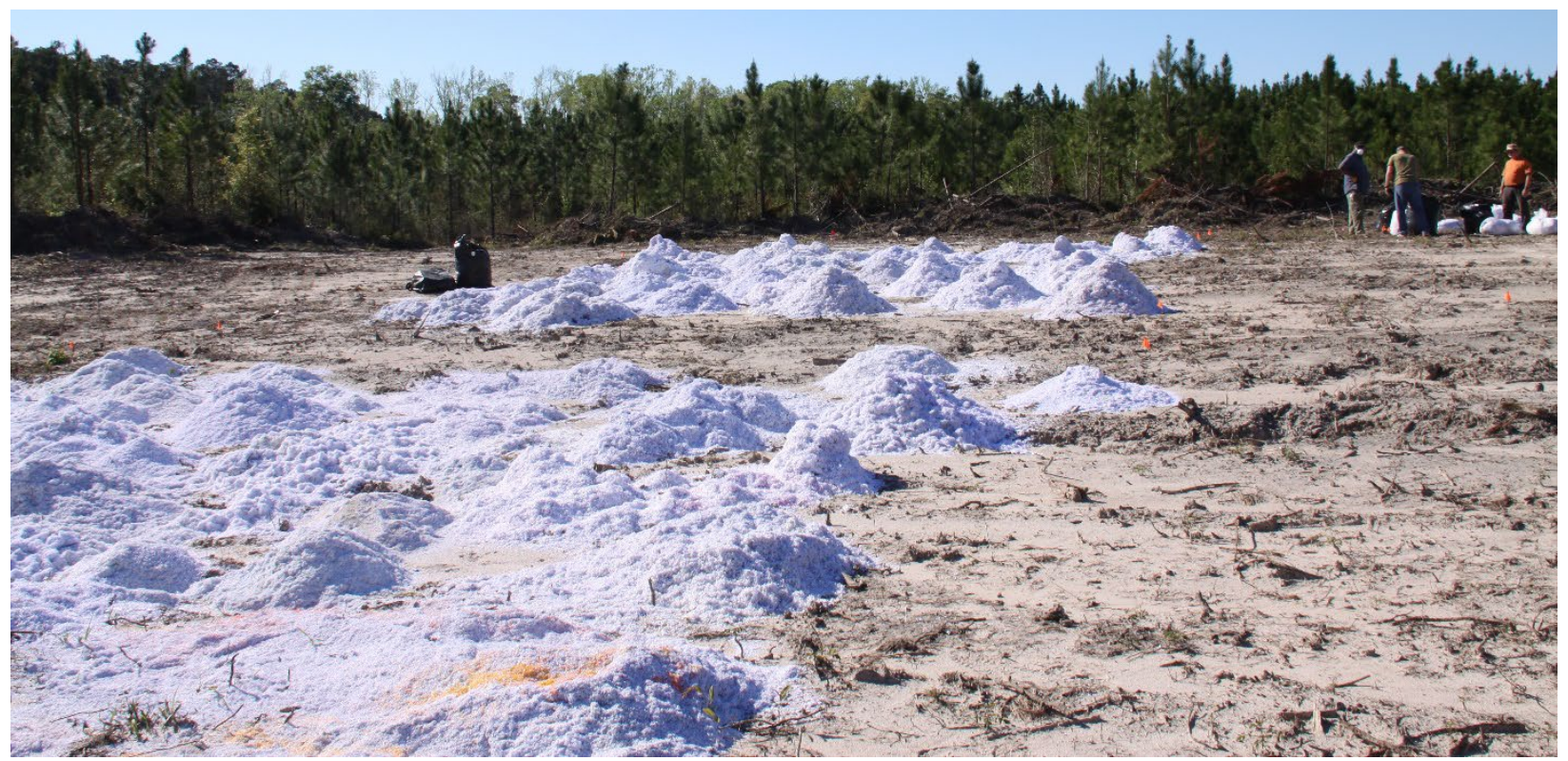

Figure 14. Paper removed from bags and awaiting final spreading.

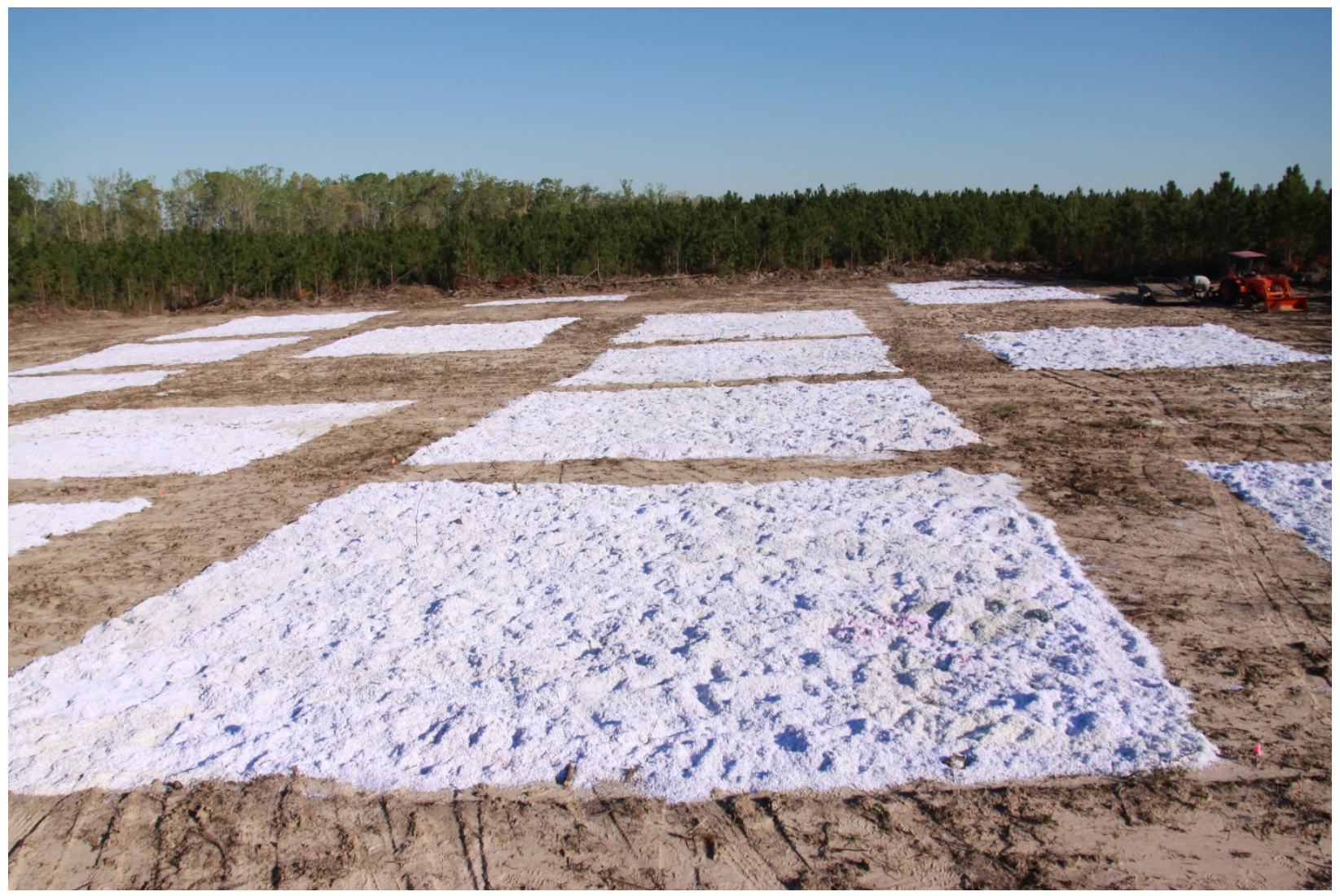

Figure 15. Paper is spread evenly over plots and awaiting incorporation. 


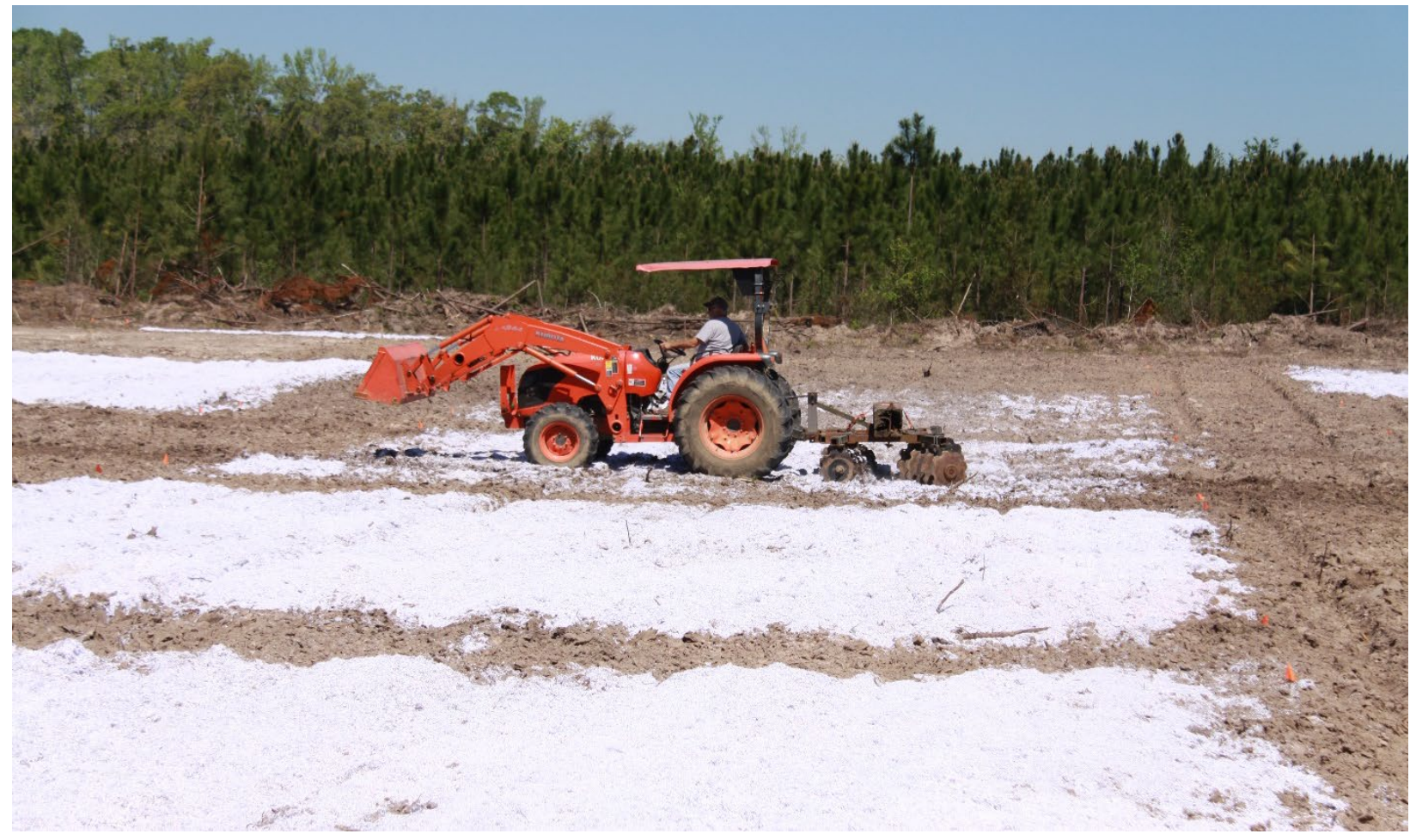

Figure 16. Paper incorporation.

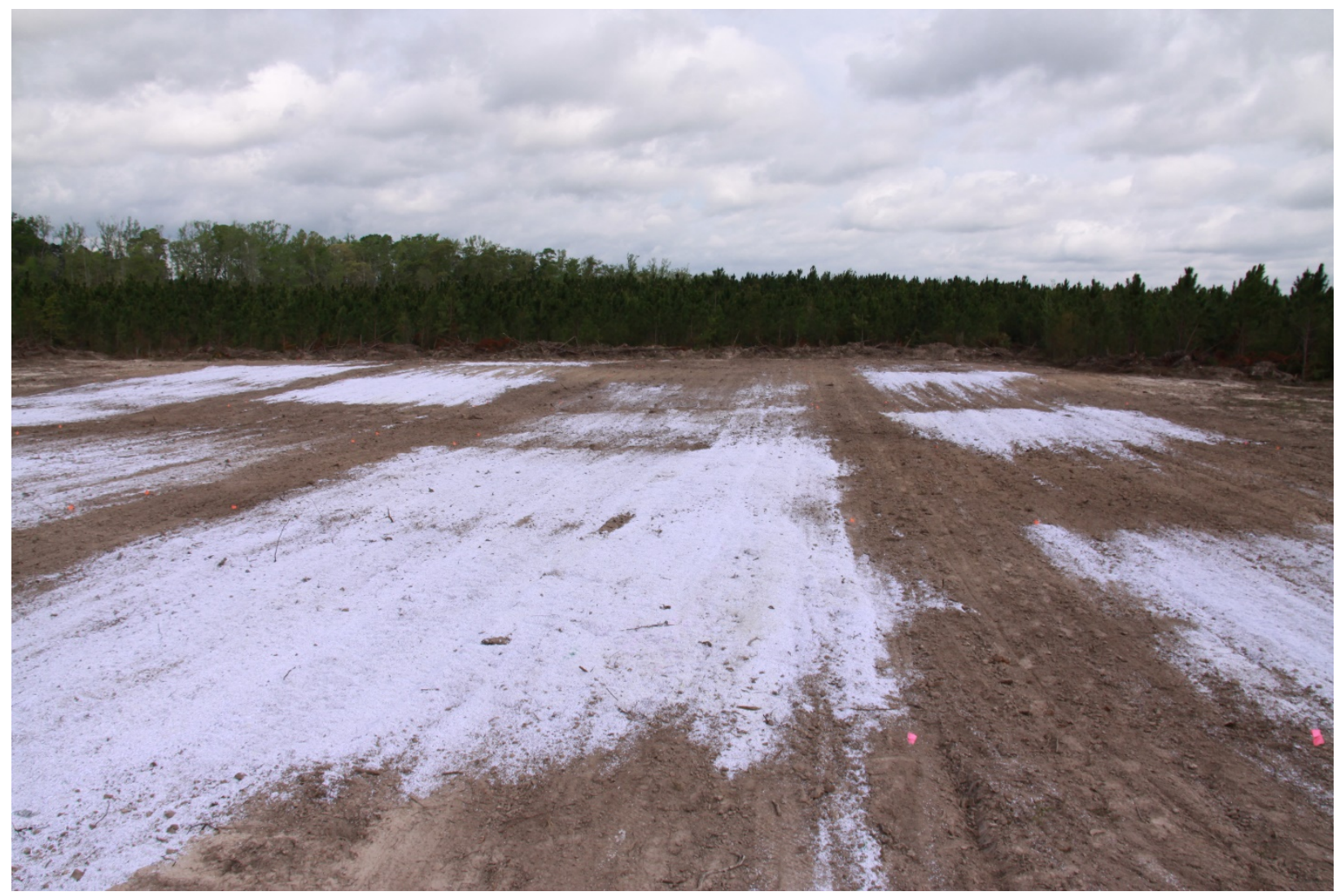

Figure 17. Final incorporated paper. Highest application rates did not incorporate into the soil, as seen here. 


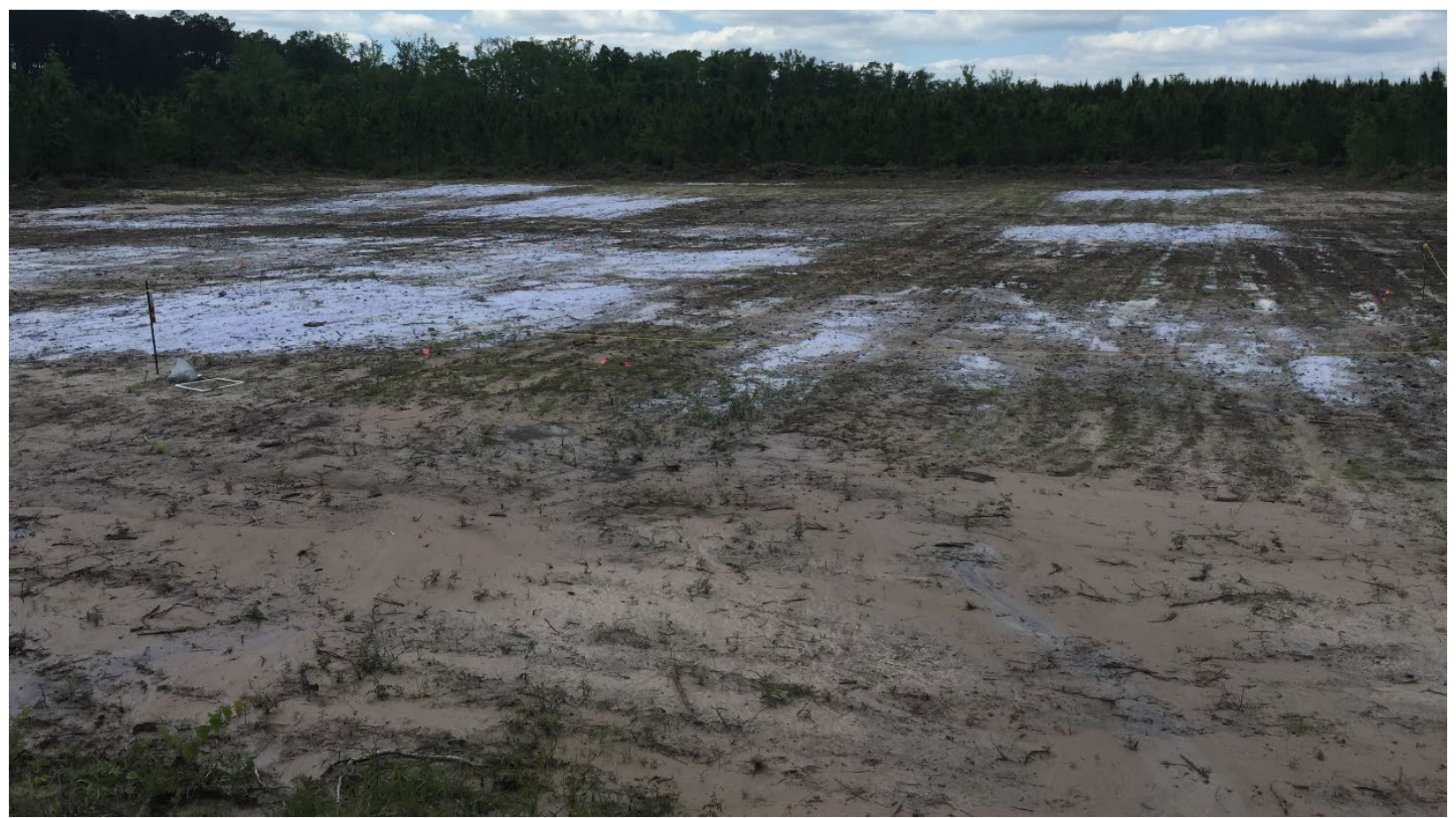

Figure 18. Site checkup one month after incorporation of paper.

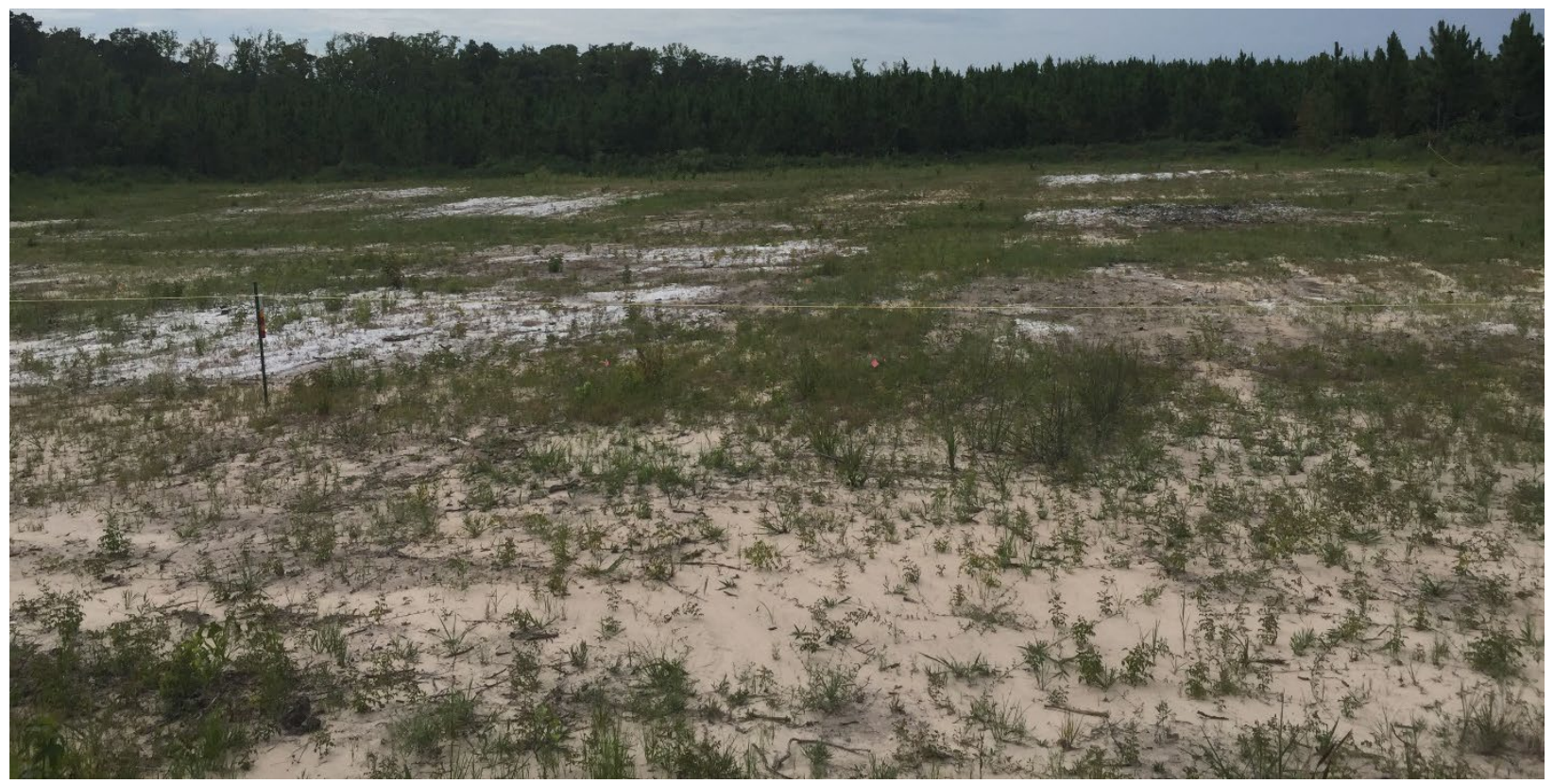

Figure 19. Site checkup 3 months after incorporation of paper. 


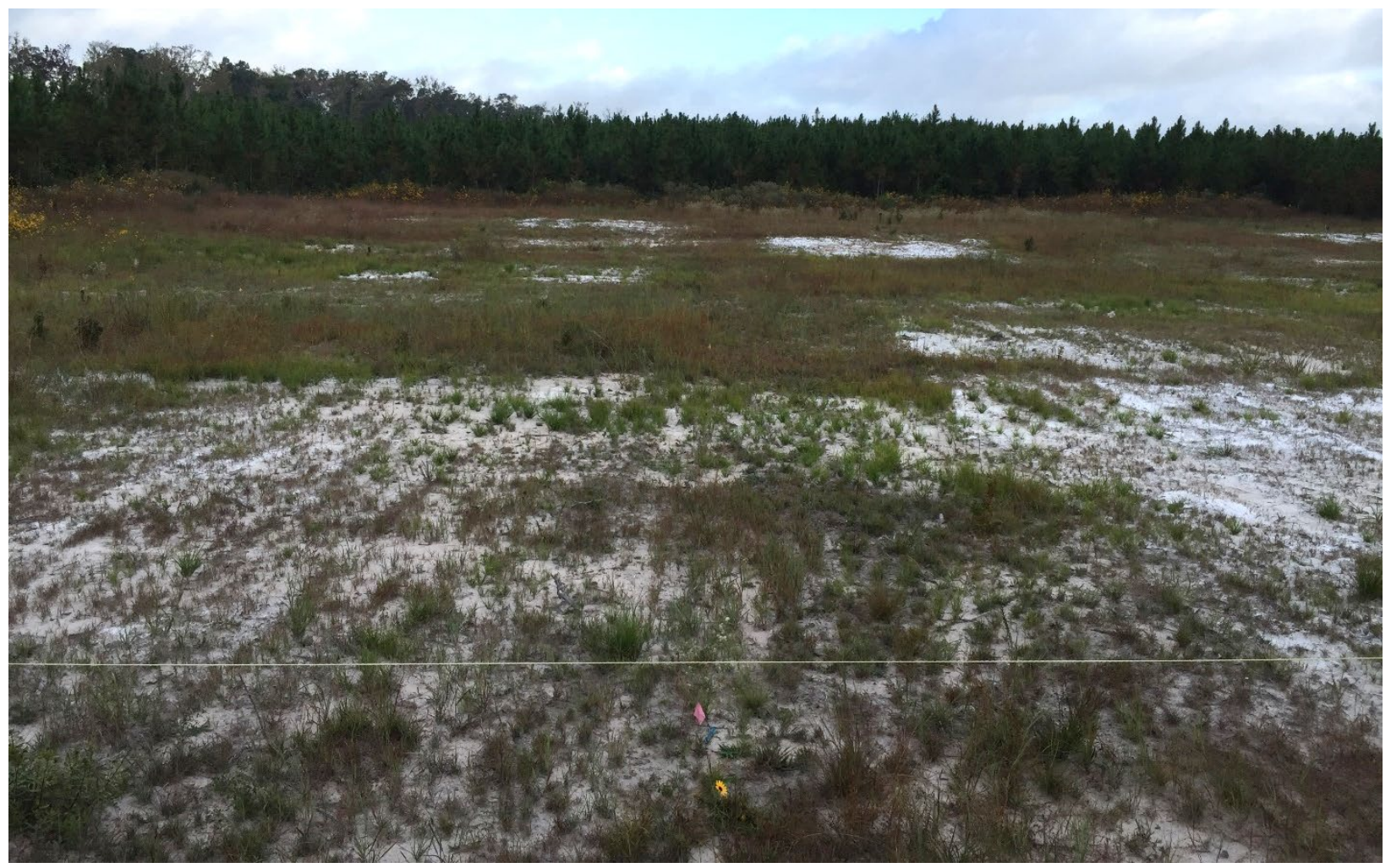

Figure 20. Site checkup after the first growing season.

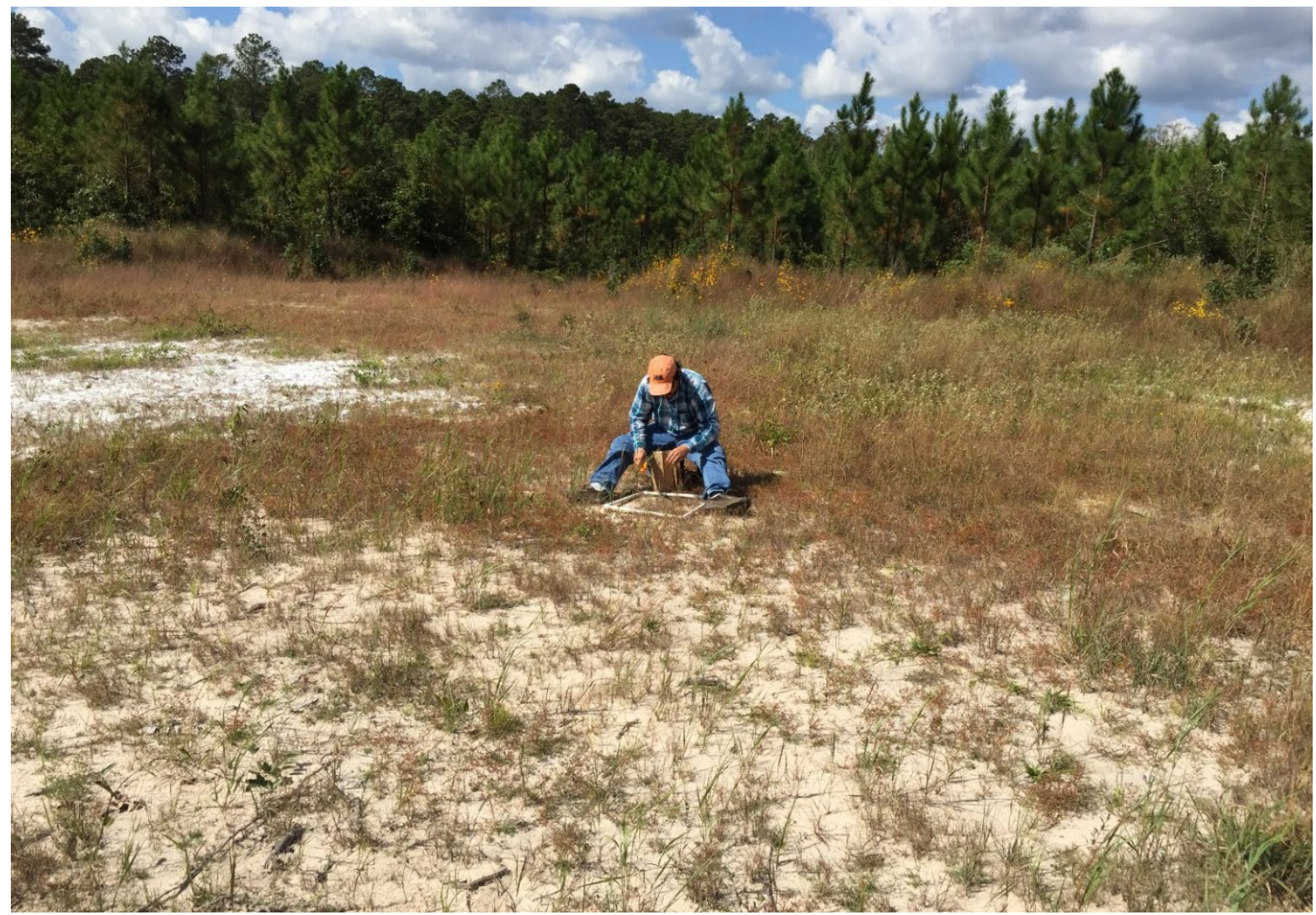

Figure 21. Biomass cutting after the first growing season. 


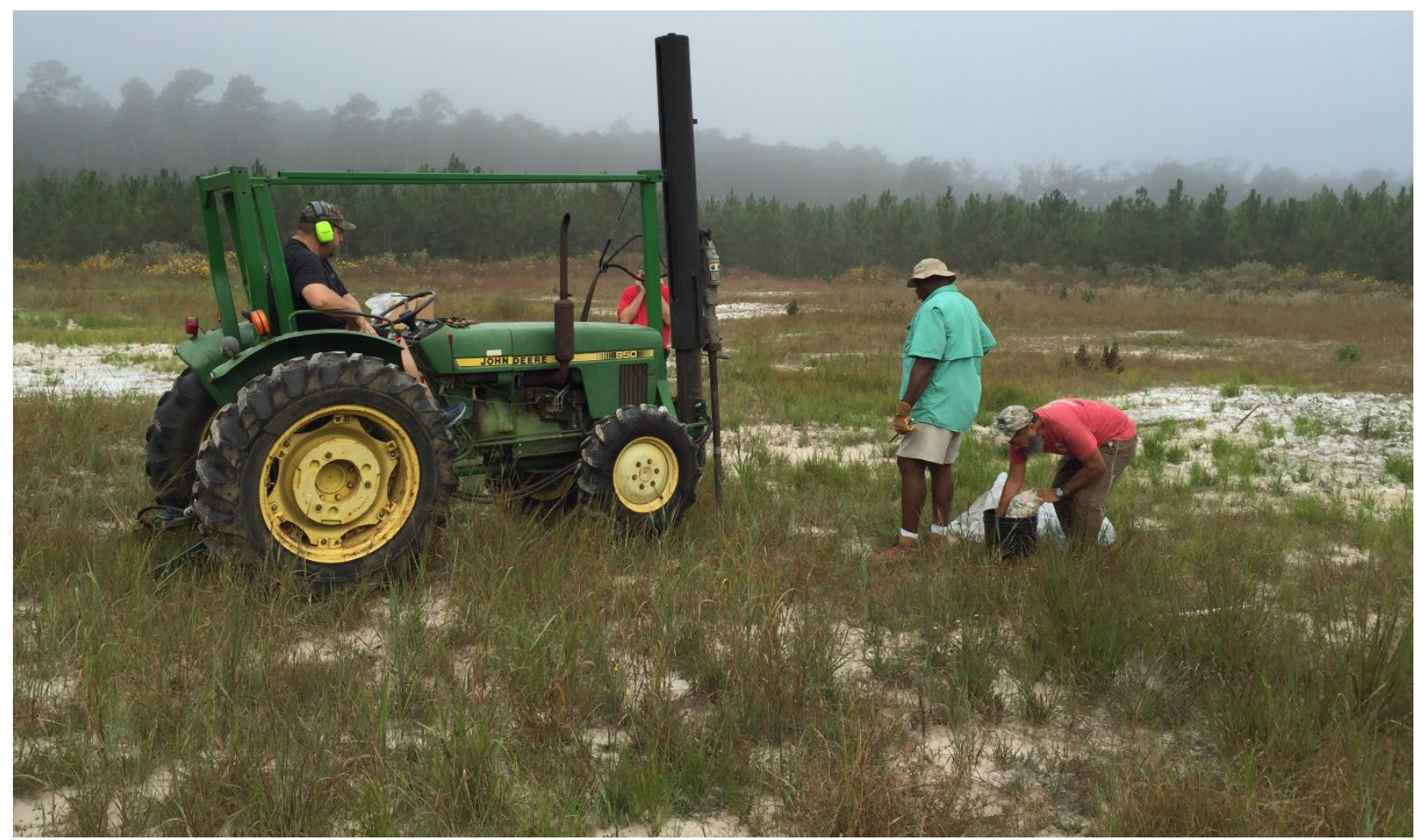

Figure 22. Soil core collection with soil rig.

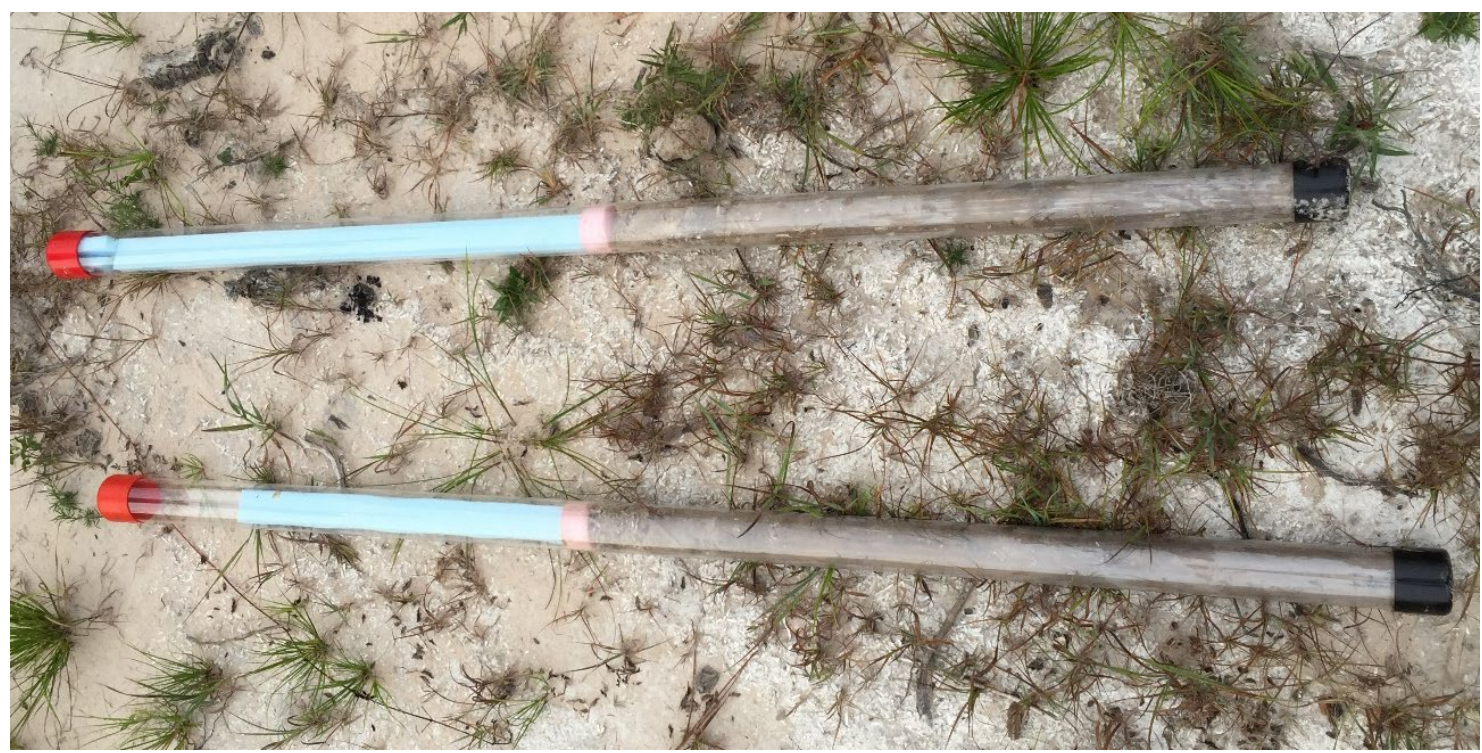

Figure 23. Soil cores stored in tubes to be sectioned by depth and analyzed. 


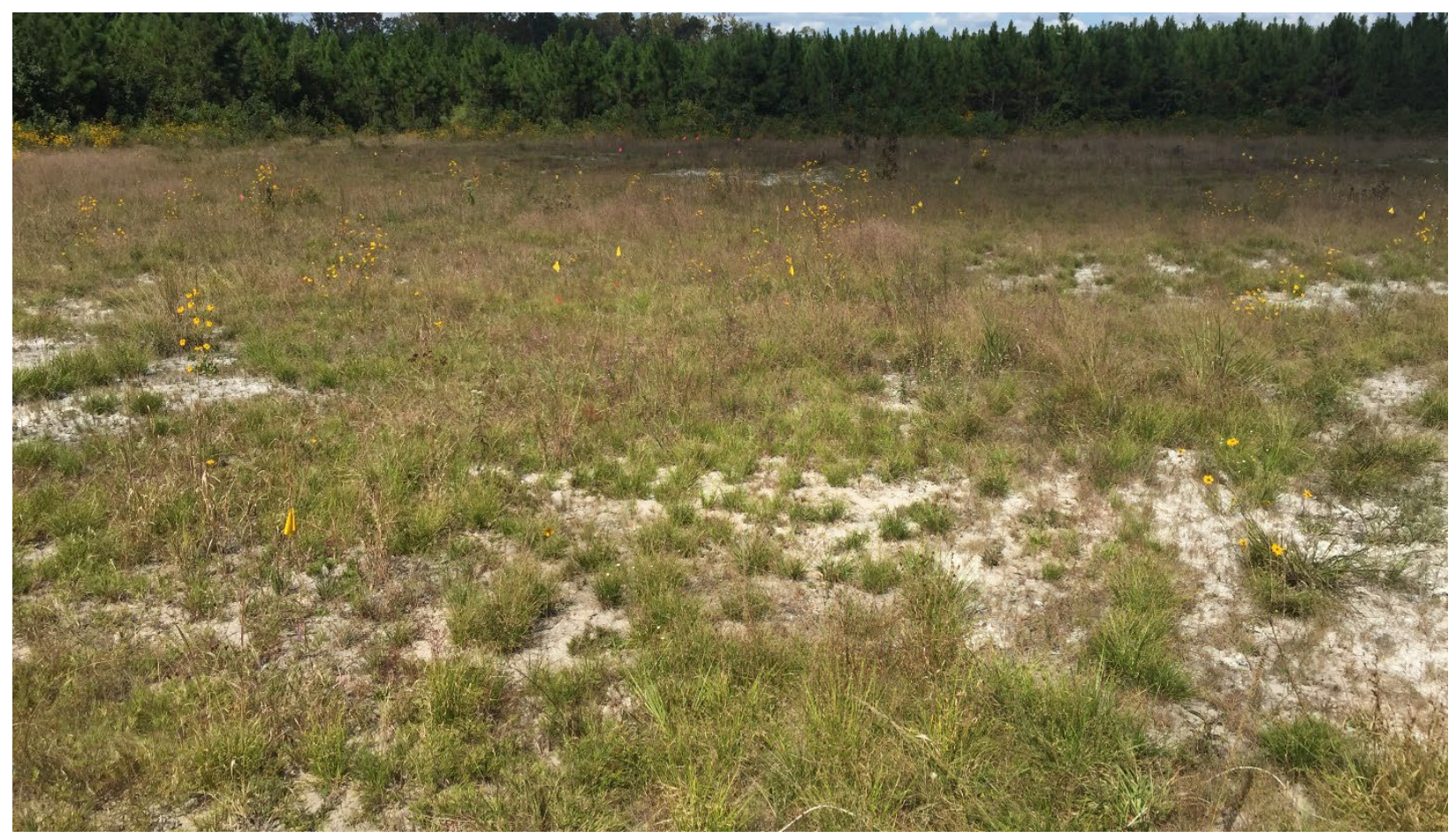

Figure 24. Briley site after 2 growing seasons.

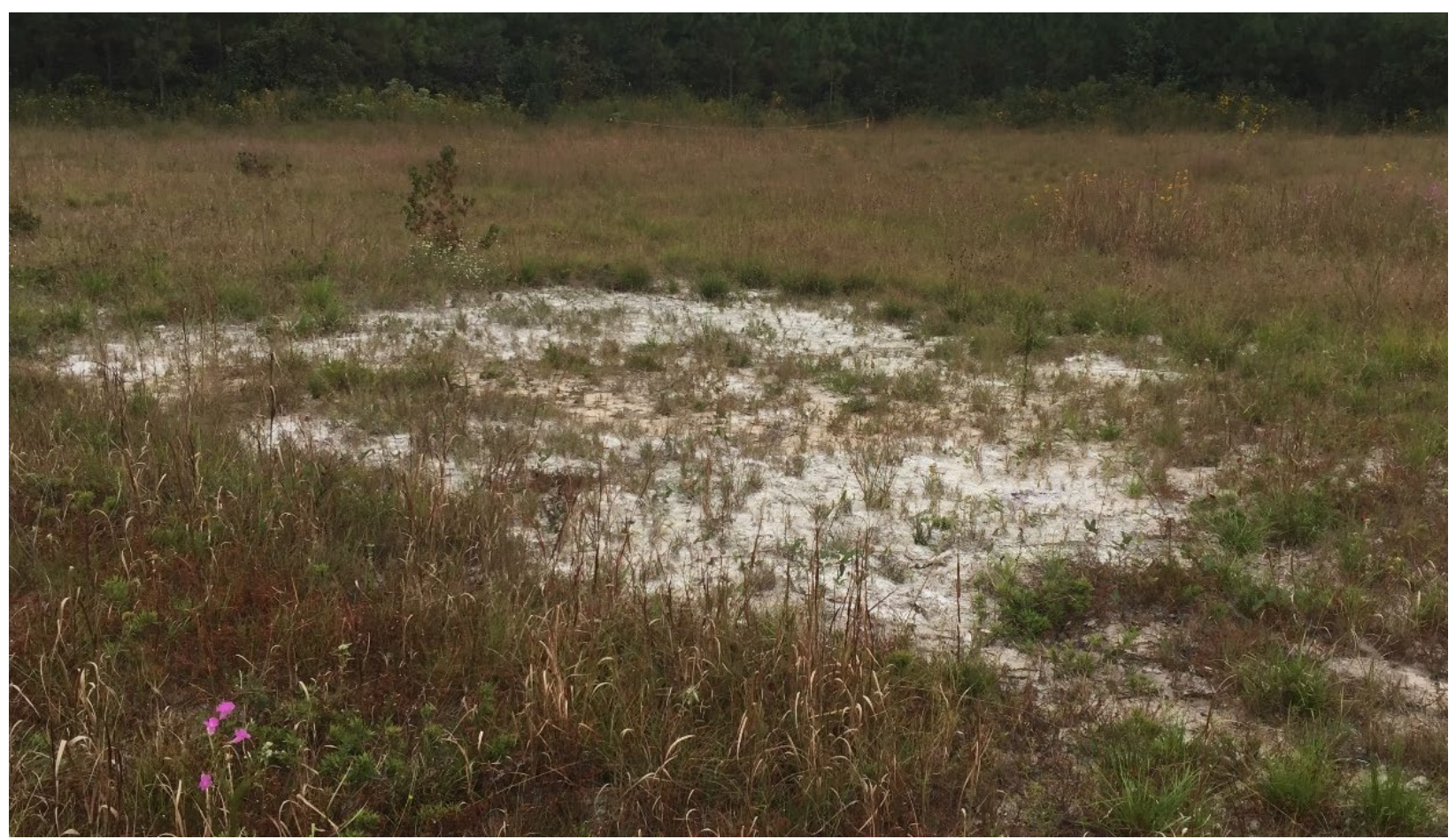

Figure 25. High paper application rate after 2 growing seasons. 


\section{Performance Metric Analysis}

Performance metric data were collected in early October of 2016 and 2017 to obtain peak standing biomass and assess the end of each growing season. Basal vegetative cover was obtained with point frames collecting 200-point samples per plot. Biomass samples were collected by clipping standing live vegetation in 3 random $0.25 \mathrm{~m}^{-2}$ quadrats per plot (Figure 21). Each sample was divided into planted grasses and non-planted vegetation. Samples were oven dried at $40{ }^{\circ} \mathrm{C}$ until mass changes ceased. Samples were weighed and converted to g dry mass per $\mathrm{m}^{-2}$ and planted grass samples were analyzed for macro- and micronutrient and heavy metal composition. Two soil samples to a depth of $60 \mathrm{~cm}$ were collected randomly from each plot (Figures 22-23). Samples were divided into 0-5, 5-10, 10-20, 20-40, and 40-60 cm increments. Bulk density, $\mathrm{pH}$, and elemental composition for macro- and micronutrients, heavy metals, and other significant agricultural properties were analyzed.

Table 6. Dates and duration of field demonstration.

\begin{tabular}{|c|c|c|c|c|c|c|c|c|c|c|c|c|}
\hline & FY 14 & & FY 15 & & & FY 16 & & & F 17 & & & Y 18 \\
\hline Activity & Q1Q2la & $\mathrm{Q} 4 \mathrm{Q}$ & $1 \mathrm{Q} 2 \mathrm{Q} 3$ & & & $\mathrm{Q} 2 \mathrm{Q} 3 \mathrm{~K}$ & $\mathrm{Q} 4$ & & $\mathrm{Q} 2 \mathrm{Q} 3 \mathrm{C}$ & & & Q2203 $\mathrm{Q} 4$ \\
\hline Site selection and characterizatio & & & & & & & & & & & & \\
\hline $\begin{array}{l}\text { Field demonstration design and } \\
\text { implementation }\end{array}$ & & & & & & & & & & & & \\
\hline Performance metric analysis & & & & & & & & & & & & \\
\hline
\end{tabular}

\subsection{SAMPLING PROTOCOL}

\section{Paper Chemical Analysis}

Three grab samples of paper were collected each month for 3 months to account for variation in the waste material. Samples were subjected to sucrose density gradients to separate all non-paper materials from the paper (pulverized paper density is $0.4 \mathrm{~g} \mathrm{ml}^{-1}$, polycarbonate density is $1.2 \mathrm{~g}$ $\mathrm{ml}^{-1}$, and PET density is $1.38 \mathrm{~g} \mathrm{ml}^{-1}$ ). All components were weighed to determine percentage composition by mass. Samples were analyzed for total $\mathrm{C}$ and $\mathrm{N}$ and extractable $\mathrm{As}, \mathrm{Cd}, \mathrm{Cr}, \mathrm{Cu}$, $\mathrm{Hg}, \mathrm{Mo}, \mathrm{Ni}, \mathrm{Pb}, \mathrm{Sb}, \mathrm{Se}, \mathrm{Zn}, \mathrm{P}, \mathrm{K}, \mathrm{Ca}, \mathrm{Fe}, \mathrm{Mg}, \mathrm{Mn}$, and $\mathrm{S}$, and bisphenol A and phthalates.

\section{Soil Characterization}

Soil samples were collected in a grid pattern in summer 2014 (see Figure 9) to a depth of $30 \mathrm{~cm}$ (12 inches). Samples were analyzed individually for total $\mathrm{C}$ and $\mathrm{N}$ and extractable As, $\mathrm{Cd}, \mathrm{Cr}$, $\mathrm{Cu}, \mathrm{Mo}, \mathrm{Ni}, \mathrm{Pb}, \mathrm{Sb}, \mathrm{Se}, \mathrm{Zn}, \mathrm{P}, \mathrm{K}, \mathrm{Ca}, \mathrm{Fe}, \mathrm{Mg}, \mathrm{Mn}$, and S. Data were utilized to identify potential locations where background concentrations were too variable to support technology demonstration and validation. No background issues were identified. 


\section{Plant Community Composition and Basal Cover}

Plant community composition was collected in October of 2016 and 2017. Random number tables were generated for $\mathrm{x}$ and $\mathrm{y}$ coordinates based on division of each plot into an imaginary grid, with random numbers indicating the location in feet from a point of origin located 2 feet in each direction (to prevent any data from being collected outside the plot) from a randomly assigned corner of the plot. At each randomly assigned grid location, the left end of the point frame was placed at the grid location, and the right end of the frame was rotated in a randomly assigned direction between 0 and $360^{\circ}$. In each plot, 20 random measurements of basal cover were taken using a 10-point frame, giving a total of 200 point observations per plot per year. Pins in the frame were lowered to the soil surface, and contact with and identity of plant species were recorded to give a measure of species composition and basal cover. Relative composition and absolute cover were calculated from this data.

\section{Plant Biomass}

Plant biomass samples were collected in October of 2016 and 2017. Random locations were determined through generation of random number tables similar to the plant composition and basal cover data, with the top left corner of a quadrat placed at the random point and the quadrat rotated in a randomly assigned direction. In each plot, 3 random $0.25 \mathrm{~m}^{2}\left(2.7 \mathrm{ft}^{2}\right)$ quadrats were laid out and all live shoots in plots were clipped to a height of $2.5 \mathrm{~cm}$ (1 inch), separated by planted grasses and non-planted vegetation, dried at $40{ }^{\circ} \mathrm{C}$ until no changes in mass resulted, and weighed.

\section{Soil Physical and Chemical Analyses}

Two soil cores from random locations (selected similarly to vegetation locations) at least $1 \mathrm{~m}$ ( 3 feet) from the edge of each plot were collected in October of 2016 and 2017 to a depth of $60 \mathrm{~cm}$ ( 2 feet). Cores were divided into depth increments of 0-5, 5-10, 10-20, 20-40, and 40-60 cm (0-2, 2-4, 4-8, 8-16, and 16-24 inches) and corresponding depth samples were pooled for each plot. Samples were analyzed for total C and N with a LECO CN 628 Analyzer. Extractable P, K, Mg, and $\mathrm{Ca}$ were analyzed using an inductively coupled plasma spectrophotometry (Hue and Evans, 1986). Total concentration of As, Cr, Cu, Mo, Ni, Pb, Sb, Zn, P, K, Ca, Fe, Mg, Mn, S, Al, B, $\mathrm{Na}, \mathrm{Ba}, \mathrm{Co}$, and $\mathrm{Li}$ were analyzed using the appropriate USEPA analysis procedure for each component, with an inductively coupled plasma spectrophotometer. Soil $\mathrm{pH}$ and bulk density were also measured using standard procedures.

\section{Shoot Chemical Analysis}

Following drying and weighing of biomass collected in 2016 and 2017, a subsample from each planted grass biomass subsample was ground and composited to yield one biomass sample per plot. Samples were analyzed by the USDA-ARS for N, P, K, Ca, Mg, S, Al, B, Cu, Fe, Mn, Mo, $\mathrm{Na}$, and $\mathrm{Zn}$, using inductively coupled plasma spectrophotometry. Total $\mathrm{N}$ was analyzed using a LECO CN 628 Analyzer (Bremner, 1996; Soltanpour et al. 1996). 
Table 7. Description of samples.

\begin{tabular}{|c|c|c|c|c|}
\hline Type & Phase & Date & Number & Description \\
\hline Paper Characterization & Baseline & 2014 & 15 & Laboratory Analysis \\
\hline Soil Characterization & Baseline & 2014 & 50 & Laboratory Analysis \\
\hline Species Composition & Evaluation & 2016, 2017 & 19200 & 10-Point Frame (200/plot/year) \\
\hline Biomass & Evalt & 2016, 2017 & 288 & $0.5 \mathrm{~m}^{2}$ Qua \\
\hline Soil Chemical Properties & Evaluation & 2016, 2017 & 480 & Laboratory A \\
\hline Properties & Evalt & 2016, 2017 & 480 & Laboratory Analysis (5/plot/year) \\
\hline Plant Nutrient Properties & Evaluation & 2016,2017 & 96 & Laboratory Analysis (1/plot/year) \\
\hline
\end{tabular}

\subsection{SAMPLING RESULTS}

\section{Paper Analysis}

Heavy metals in paper samples were analyzed by Environmental Resource Analysts, Inc. (Auburn, AL). Phthalates and bisphenol A were analyzed by Applied Technical Services, Inc. (Marietta, GA). Agricultural elemental analysis was conducted by the Auburn University Soil, Forage, and Water Testing Laboratory (Auburn, AL). No phthalates were detected in any sample at a detection limit of 50 parts per million (Table 8). Bisphenol A had a mean concentration of 483 parts per billion.

Table 8. Mean bisphenol A and phthalate concentrations in Fort Polk pulverized paper samples.

\begin{tabular}{|c|c|c|c|c|c|c|c|}
\hline \multirow[b]{2}{*}{ BPA (ppb) } & \multicolumn{7}{|c|}{ Phthalate Concentration (ppm) } \\
\hline & DnHP & DnBP & $\mathrm{BBP}$ & DEHP & $\mathrm{DnOP}$ & DINP & DIDP \\
\hline 483 & $<50$ & $<50$ & $<50$ & $<50$ & $<50$ & $<50$ & $<50$ \\
\hline
\end{tabular}

$\mathrm{BPA}=$ bisphenol A, DnHP $=$ di-n-hexyl phthatalate, $\mathrm{DnBP}=$ di-n-butyl phthalate, $\mathrm{BBP}=$ butyl benzyl phthalate, $\mathrm{DEHP}=$ di-ethyl hexyl phthalate, $\mathrm{DnOP}=$ di-n-octyl phthalate, DINP = diisononyl phthalate, DIDP $=$ di-isodecyl phthalate.

Of the heavy metals regulated by EPA for land application of wastes, only copper and zinc were detected in the paper (Table 9). To compare annual and cumulative loading limits to EPA regulations, a conservative estimate using detection limits was used, although actual concentrations could be orders of magnitude lower than these estimates (Table 9). Based on these estimates, molybdenum would be the limiting factor for land application, at a maximum annual application limit of 185 tons acre ${ }^{-1}$ and cumulative loading limit of 3700 tons acre $^{-1}$. Using only the metals that had detectable concentrations in the paper, zinc would be the limiting factor for land application, at a maximum annual application limit of 3122 tons acre ${ }^{-1}$ and cumulative loading limit of 62440 tons acre ${ }^{-1}$. Agricultural analysis indicated the paper had a C:N ratio around 200 and contained variable levels of plant nutrients, with calcium being the highest (Table 10). 
Table 9. Mean heavy metal concentrations of Fort Polk pulverized paper samples

Concentration (ppm)

Antimony Arsenic Cadmium Chromium Copper Lead Mercury Molybdenum Nickel Selenium Zinc

$\begin{array}{lllllllllll}<2.58 & <2.58 & <0.4 & <1.69 & 1.78 & <2.1 & <0.03 & <2.17 & <1.21 & <2.13 & 20.0\end{array}$

Additional paper samples were collected from installations across the country to compare spatial variation in regulated contaminants and other constituents in pulverized paper waste. These installations also included samples representing worst-case scenarios with regards to potential contamination (Table 11). One sample was a batch of thermal cash register receipts whose inks are high in bisphenol A. Another sample contained compact discs ( $11 \%$ by weight), that are another contaminant source of bisphenol A, as well as antimony. The final spiked sample was from an industrial shredder where pallets and other materials are mixed with paper. The thermal cash register receipts had much lower levels of bisphenol A compared to the compact discs. The industrial shredder sample had higher chromium, nickel, and zinc, all of which were still well below the EPA limits. The full analyses of metals and agricultural elements from these installation samples outside of Fort Polk are provided in Tables 12 and 13. 


\begin{tabular}{|c|c|c|c|c|c|c|c|c|c|c|c|c|c|c|c|}
\hline \multirow[b]{3}{*}{$\underline{\text { Sample }}$} & \multirow[b]{3}{*}{ Date } & \multirow[b]{3}{*}{ C:N } & \multicolumn{13}{|c|}{ Agricultural and Other Elements } \\
\hline & & & \multicolumn{3}{|c|}{$(\%)$} & \multicolumn{10}{|c|}{$(\mathrm{ppm})$} \\
\hline & & & $\underline{\mathrm{C}}$ & $\underline{\mathrm{N}}$ & $\underline{\mathrm{Ca}}$ & $\underline{\mathrm{Mg}}$ & $\underline{\mathrm{K}}$ & $\underline{P}$ & $\underline{S}$ & $\underline{\mathrm{Fe}}$ & $\mathrm{Mn}$ & $\underline{B}$ & $\mathrm{Na}$ & $\underline{\mathrm{Al}}$ & $\underline{\mathrm{Ba}}$ \\
\hline 1 & 17-Jun-2014 & 255 & 39.6 & 0.16 & 4.3 & 1300 & 110 & $<0.1$ & 760 & 2429 & 26 & 2 & 1717 & 1148 & 8 \\
\hline 2 & 24-Jun-2014 & 181 & 37.6 & 0.21 & 6.7 & 1600 & 131 & $<0.1$ & 930 & 3023 & 18 & 8 & 1456 & 667 & 101 \\
\hline 3 & 1-Jul-2014 & 178 & 36.5 & 0.21 & 6.2 & 1500 & 108 & $<0.1$ & 1420 & 237 & 6 & 0.9 & 1581 & 613 & 15 \\
\hline 4 & 14-Jul-2014 & 192 & 38.1 & 0.20 & 5.5 & 1400 & 194 & $<0.1$ & 880 & 2282 & 24 & 3 & 1919 & 1127 & 8 \\
\hline 5 & 23-Jul-2014 & 164 & 37.2 & 0.23 & 5.8 & 1300 & 126 & 57 & 820 & 1886 & 20 & 2 & 1871 & 1007 & 14 \\
\hline 6 & 29-Jul-2014 & 188 & 38.1 & 0.20 & 5.1 & 1200 & 198 & $<0.1$ & 780 & 1548 & 16 & 2 & 2085 & 1037 & 137 \\
\hline 7 & 6-Aug-2014 & 262 & 38.5 & 0.15 & 4.8 & 1400 & 128 & $<0.1$ & 740 & 293 & 6 & 2 & 1667 & 514 & 9 \\
\hline 8 & 13-Aug-2014 & 209 & 36.6 & 0.18 & 6.9 & 1600 & 207 & $<0.1$ & 800 & 461 & 6 & 2 & 1476 & 768 & 15 \\
\hline 9 & 21-Aug-2014 & 182 & 38.7 & 0.21 & 4.7 & 1100 & 220 & $<0.1$ & 930 & 2357 & 22 & 3 & 1831 & 859 & 53 \\
\hline 10 & 16-Sep-2014 & 205 & 38.2 & 0.19 & 6.3 & 1600 & 130 & $<0.1$ & 770 & 1104 & 9 & 3 & 1551 & 2120 & 13 \\
\hline Mean & & 202 & 37.9 & 0.19 & 5.6 & 1400 & 155 & 5.79 & 880 & 1562 & 15 & 3 & 1716 & 986 & 37 \\
\hline
\end{tabular}

\begin{tabular}{|c|c|c|c|c|c|c|c|c|c|c|c|c|c|}
\hline \multirow[b]{2}{*}{ Source } & \multicolumn{12}{|c|}{ Concentration (ppm) } & \multirow{2}{*}{$\begin{array}{l}\text { (ppb) } \\
\text { BPA }\end{array}$} \\
\hline & $\underline{\mathrm{Sb}}$ & $\underline{\text { As }}$ & $\underline{\mathrm{Cd}}$ & $\underline{\mathrm{Cr}}$ & $\underline{\mathrm{Cu}}$ & $\underline{\mathrm{Pb}}$ & $\underline{\mathrm{Hg}}$ & $\underline{\text { Mo }}$ & $\underline{\mathrm{Ni}}$ & $\underline{\mathrm{Se}}$ & $\underline{\mathrm{Zn}}$ & $\underline{\text { Phthalates }}$ & \\
\hline Spiked with CDs & $<2.6$ & $<2.6$ & $<0.4$ & 14.8 & 1.6 & $<2.1$ & 0.19 & $<2.2$ & 8.8 & $<2.1$ & 17 & $<50$ & 14205 \\
\hline Industrial Shredder & $<2.5$ & $<2.5$ & $<0.4$ & 362 & 5.0 & $<2.0$ & $<0.03$ & 2.2 & 164 & $<2.0$ & 79 & $<50$ & 4078 \\
\hline Polk Mean & $<2.58$ & $<2.58$ & $<0.4$ & 1.69 & 1.78 & $<2.07$ & $<0.03$ & $<2.17$ & $<1.21$ & $<2.13$ & 20 & $<50$ & 483 \\
\hline EPA Limits & - & 75 & 85 & 3000 & 4300 & 840 & 57 & 75 & 420 & 100 & 7500 & & \\
\hline
\end{tabular}




\begin{tabular}{|c|c|c|c|c|c|c|c|c|c|c|c|c|c|}
\hline \multirow[b]{2}{*}{ Source } & \multicolumn{12}{|c|}{ Concentration (ppm) } & \multirow{2}{*}{$\begin{array}{l}(\mathrm{ppb}) \\
\underline{\mathrm{BPA}}\end{array}$} \\
\hline & $\underline{\mathrm{Sb}}$ & $\underline{\mathrm{As}}$ & $\underline{\mathrm{Cd}}$ & $\underline{\mathrm{Cr}}$ & $\underline{\mathrm{Cu}}$ & $\underline{\mathrm{Pb}}$ & $\underline{\mathrm{Hg}}$ & Mo & $\underline{\mathrm{Ni}}$ & $\underline{\mathrm{Se}}$ & $\underline{\mathrm{Zn}}$ & Phthalates & \\
\hline Polk Mean & 2.58 & 2.58 & 0.4 & 1.69 & 1.78 & 2.07 & 0.03 & 2.17 & 1.21 & 2.13 & 20 & $<50$ & 483 \\
\hline Installation 1 & $<2.6$ & $<2.6$ & $<0.4$ & 2.5 & 4.7 & $<2.1$ & $<0.03$ & $<2.2$ & 3.9 & $<2.1$ & 49 & $<50$ & 7144 \\
\hline Installation 2 Clean & $<2.6$ & $<2.6$ & $<0.4$ & 10.7 & $<.5$ & $<2.1$ & $<0.03$ & $<2.2$ & 4.2 & $<2.1$ & 6 & $<50$ & $<15$ \\
\hline Installation 2 Dirty & $<2.6$ & $<2.6$ & $<0.4$ & $<1.3$ & $<.5$ & $<2.1$ & $<0.03$ & $<2.2$ & 1.2 & $<2.0$ & 5 & $<50$ & 493 \\
\hline Installation 3 with CDs & $<2.6$ & $<2.6$ & $<0.4$ & 14.8 & 1.6 & $<2.1$ & 0.19 & $<2.2$ & 8.8 & $<2.1$ & 17 & $<50$ & 14205 \\
\hline $\begin{array}{l}\text { Installation } 3 \text { Clean } \\
\text { Installation } 4 \text { Industrial }\end{array}$ & $<2.6$ & $<2.6$ & $<0.4$ & $<1.3$ & 1.5 & $<2.0$ & $<0.03$ & $<2.1$ & $<1.0$ & $<2.0$ & 7 & $<50$ & 69 \\
\hline Shredder & $<2.5$ & $<2.5$ & $<0.4$ & 362 & 5.0 & $<2.0$ & $<0.03$ & 2.2 & 164 & $<2.0$ & 79 & $<50$ & 4078 \\
\hline Installation 4 Clean & $<2.5$ & $<2.5$ & $<0.4$ & 1.8 & 4.3 & $<2.0$ & $<0.03$ & $<2.1$ & 1.2 & $<2.0$ & 11 & $<50$ & 1197 \\
\hline EPA Limits & - & 75 & 85 & 3000 & 4300 & 840 & 57 & 75 & 420 & 100 & 7500 & & \\
\hline
\end{tabular}

Table 13. Agricultural properties of paper samples across multiple installations.

\begin{tabular}{|c|c|c|c|c|c|c|c|c|c|c|c|c|c|c|}
\hline \multirow[b]{3}{*}{ Source } & \multirow[b]{3}{*}{$\underline{\mathrm{C}: \mathrm{N}}$} & \multicolumn{13}{|c|}{ Agricultural and Other Elements } \\
\hline & & \multicolumn{3}{|c|}{$(\%)$} & \multicolumn{10}{|c|}{$(\mathrm{ppm})$} \\
\hline & & $\underline{\mathrm{C}}$ & $\underline{\mathrm{N}}$ & $\underline{\mathrm{Ca}}$ & $\underline{\mathrm{Mg}}$ & $\underline{\mathrm{K}}$ & $\underline{\mathrm{P}}$ & $\underline{\mathrm{S}}$ & $\underline{\mathrm{Fe}}$ & $\underline{\mathrm{Mn}}$ & $\underline{B}$ & $\mathrm{Na}$ & $\underline{\mathrm{Al}}$ & $\underline{\mathrm{Ba}}$ \\
\hline Installation 1 & $\overline{249}$ & 39.5 & 0.16 & $\overline{4.0}$ & $\overline{1200}$ & 309 & $<\overline{0.1}$ & 790 & $\overline{559}$ & 5 & 0.8 & $\overline{1623}$ & 2471 & 17 \\
\hline Installation 2 Clean & 178 & 37.1 & 0.21 & 5.4 & 1400 & 124 & $<0.1$ & 1000 & 163 & 5 & 0.8 & 1496 & 694 & 66 \\
\hline Installation 2 Dirty & 184 & 39.5 & 0.22 & 4.8 & 1300 & 107 & $<0.1$ & 900 & 81 & 4 & 1.0 & 1461 & 562 & 11 \\
\hline Installation 3 with CDs & 243 & 42.5 & 0.18 & 4.7 & 1500 & 121 & $<0.1$ & 820 & 189 & 10 & 0.5 & 1265 & 993 & 14 \\
\hline Installation 3 Clean & 248 & 37.0 & 0.15 & 6.2 & 1600 & 129 & $<0.1$ & 780 & 740 & 8 & 2.0 & 1494 & 1052 & 12 \\
\hline $\begin{array}{c}\text { Installation } 4 \text { Industrial } \\
\text { Shredder }\end{array}$ & 218 & 38.4 & 0.18 & 4.8 & 1200 & 154 & $<0.1$ & 730 & 2948 & 22 & 3 & 1468 & 523 & 7 \\
\hline Installation 4 Clean & 221 & 37.4 & 0.17 & 6.4 & 1600 & 355 & 133 & 680 & 655 & 10 & 5 & 1470 & 1146 & 13 \\
\hline Mean & 220 & 38.8 & 0.18 & 5.2 & 1400 & 186 & 19.1 & 814 & 762 & 9 & 1.9 & 1468 & 1063 & 20 \\
\hline
\end{tabular}




\section{Initial Site Characterization}

Analysis of site soils prior to implementation of demonstration plots indicated no exceptional physical or chemical property gradients across either site, and gave no indication of previous deposition of regulated compounds.

\section{Soil Respiration}

Soil respiration measurement from the Briley site indicated that paper application increased soil respiration throughout the first growing season as the paper material was decomposed by the soil microbial community. The 16 tons ac ${ }^{-1}$ paper application rate degraded faster than the 32 tons ac $^{-}$ ${ }^{1}$ paper application rate (Figure 26), as evidenced by a higher rate of respiration halfway through the growing season and a lower rate at the end. This observation is likely due to the higher application rates not incorporating fully into the soil and creating a crust on the soil surface that resisted decomposition, as was found with both the 24 and 32 tons ac ${ }^{-1}$ paper application rates. However, the 16 tons $\mathrm{ac}^{-1}$ paper application rate incorporated fully into the soil and indicates that this rate decomposed throughout the entire growing season, which will immobilize nitrogen at least during this period.

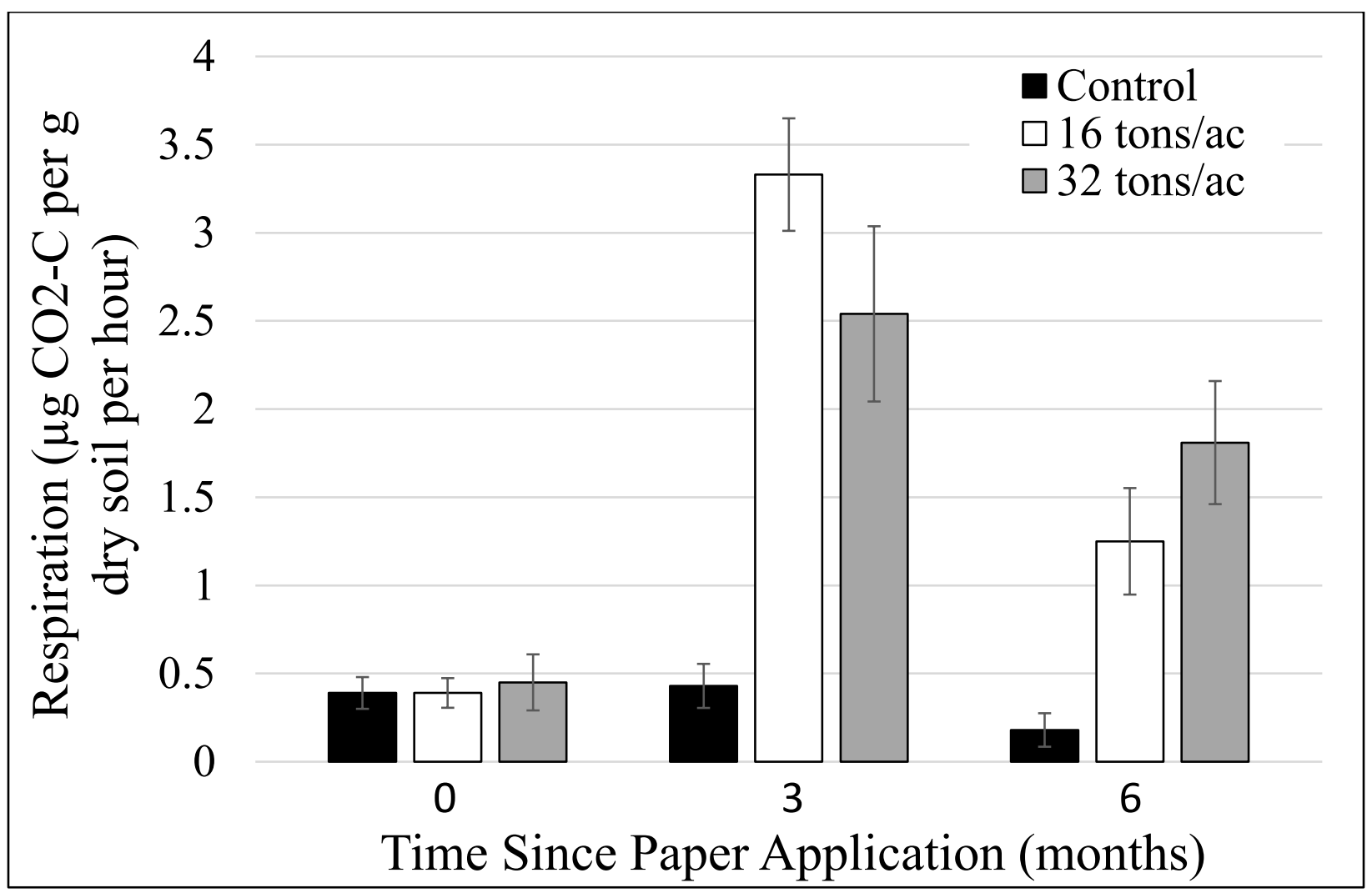

Figure 26. Soil respiration at the Briley site. Samples included the control, middle, and highest paper application treatments in the first growing season following paper application. Bars are \pm 1 standard error. 


\section{Plant Cover and Composition}

Mean total basal cover of vegetation at the Briley site averaged 7.7\% in 2016 and $11.3 \%$ in 2017, while averaging $11.2 \%$ in 2016 and $7.3 \%$ in 2017 at the Eastwood site. Because different paper application rates were applied to the two demonstration sites (and because dependent variables exhibited significant site effects when overlapping rates were analyzed together), data were analyzed for each site separately. At the Briley site, mean total basal vegetative cover was highest in the standard practice plots in both years and lowest at the highest paper application rate (Figure 27). Mean planted grass basal cover was highest in the 8 tons $\mathrm{ac}^{-1}$ paper application rate and lowest at the highest paper application rates in year 1 (Figure 28). In year 2, the highest

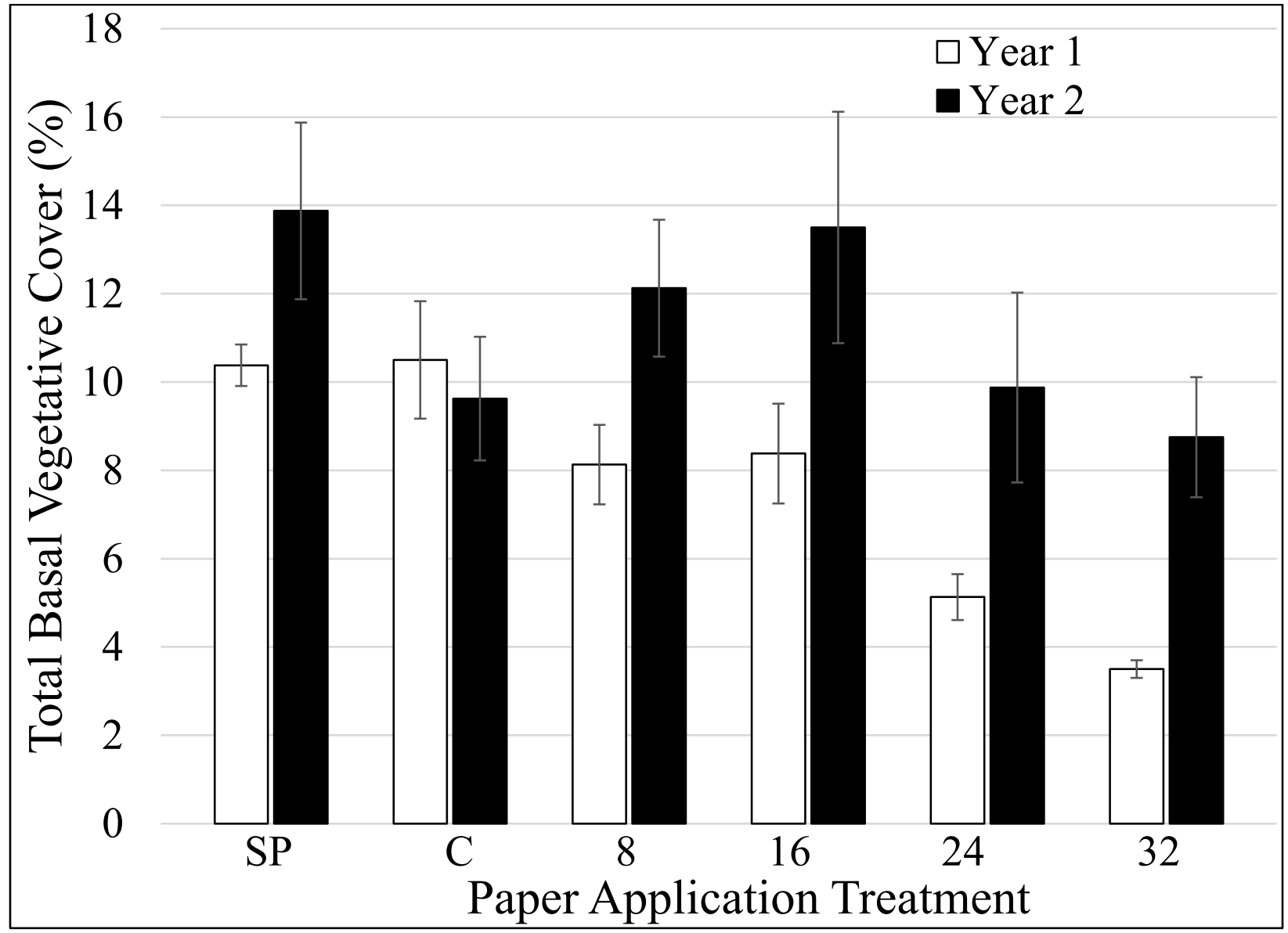

Figure 27. Mean total basal vegetative cover at the Briley site. Means are across both years and paper application treatments. Bars are \pm 1 standard error. Treatments are as follows: SP $=$ standard practice treatment, $\mathrm{C}=$ control, $8=8$ tons ac ${ }^{-1}$ paper, $16=16$ tons ac $^{-1}$ paper, $24=24$ tons ac ${ }^{-1}$ paper, and $32=32$ tons ac $\mathrm{c}^{-1}$ paper.

paper application rate produced the highest mean planted grass basal cover while the 24 tons ac ${ }^{-1}$ paper application treatment produced the lowest. Mean relative planted grass basal cover was highest in the 8 ton $\mathrm{ac}^{-1}$ treatment in the first year, but highest in the 24 ton $\mathrm{ac}^{-1}$ treatment in year 2 (Figure 29). The standard practice plots yielded the lowest mean relative planted grass basal cover in both years. Mean relative weed basal cover was highest in the standard practice 
treatment in the first year and lowest in the lower paper application rates (Figure 30). In year 2, the control treatment produced the highest mean relative weed basal cover, followed by the standard practice treatment, while the paper application treatments all had lower mean relative basal cover of weeds.

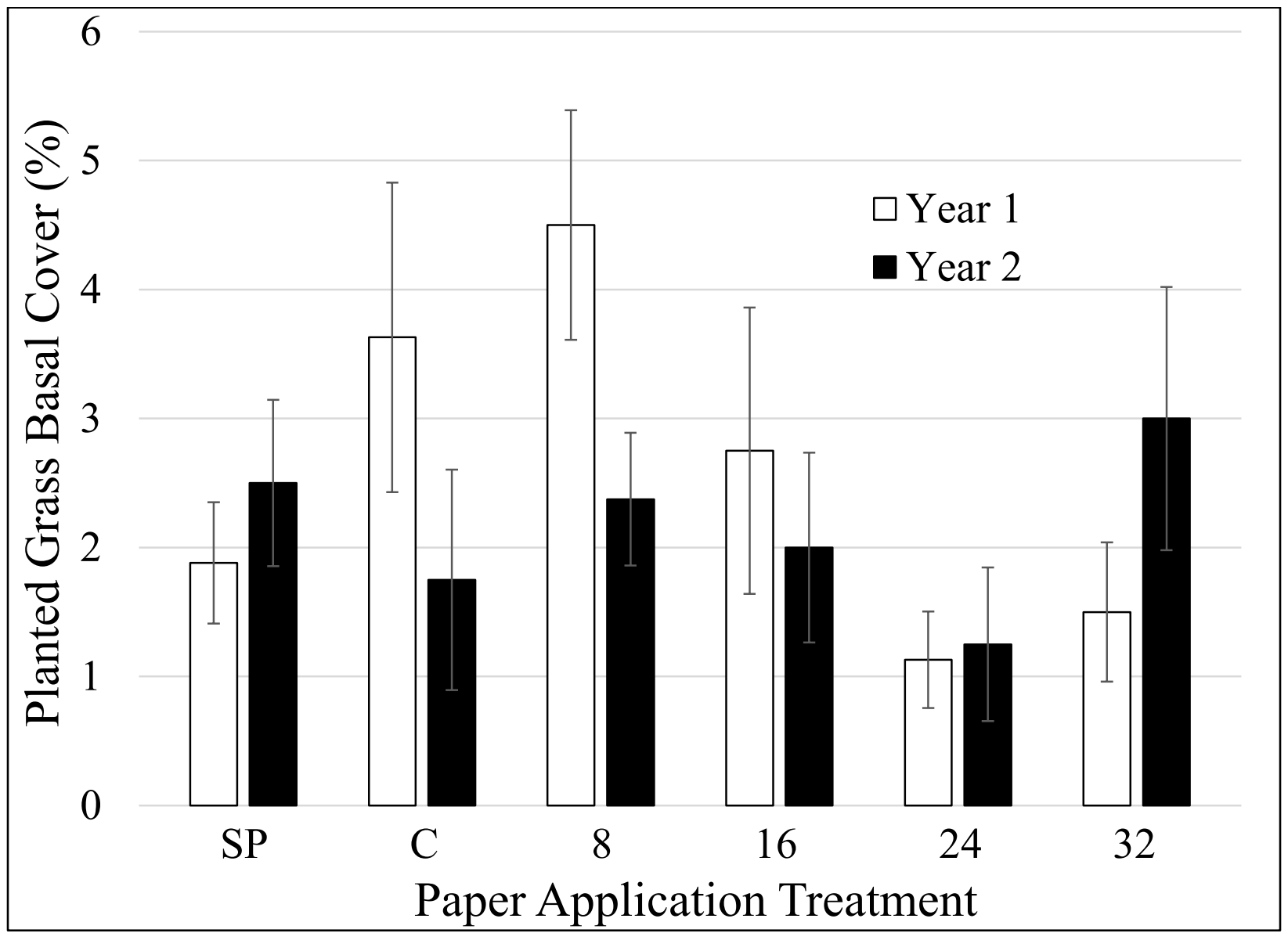

Figure 28. Mean planted grass basal cover at the Briley site. Means are across both years and paper application treatments. Bars are \pm 1 standard error. Treatments are as follows: $\mathrm{SP}=$ standard practice treatment, $\mathrm{C}=$ control, $8=8$ tons ac ${ }^{-1}$ paper, $16=16$ tons ac ${ }^{-1}$ paper, $24=24$ tons ac ${ }^{-1}$ paper, and $32=32$ tons ac ${ }^{-1}$ paper. 


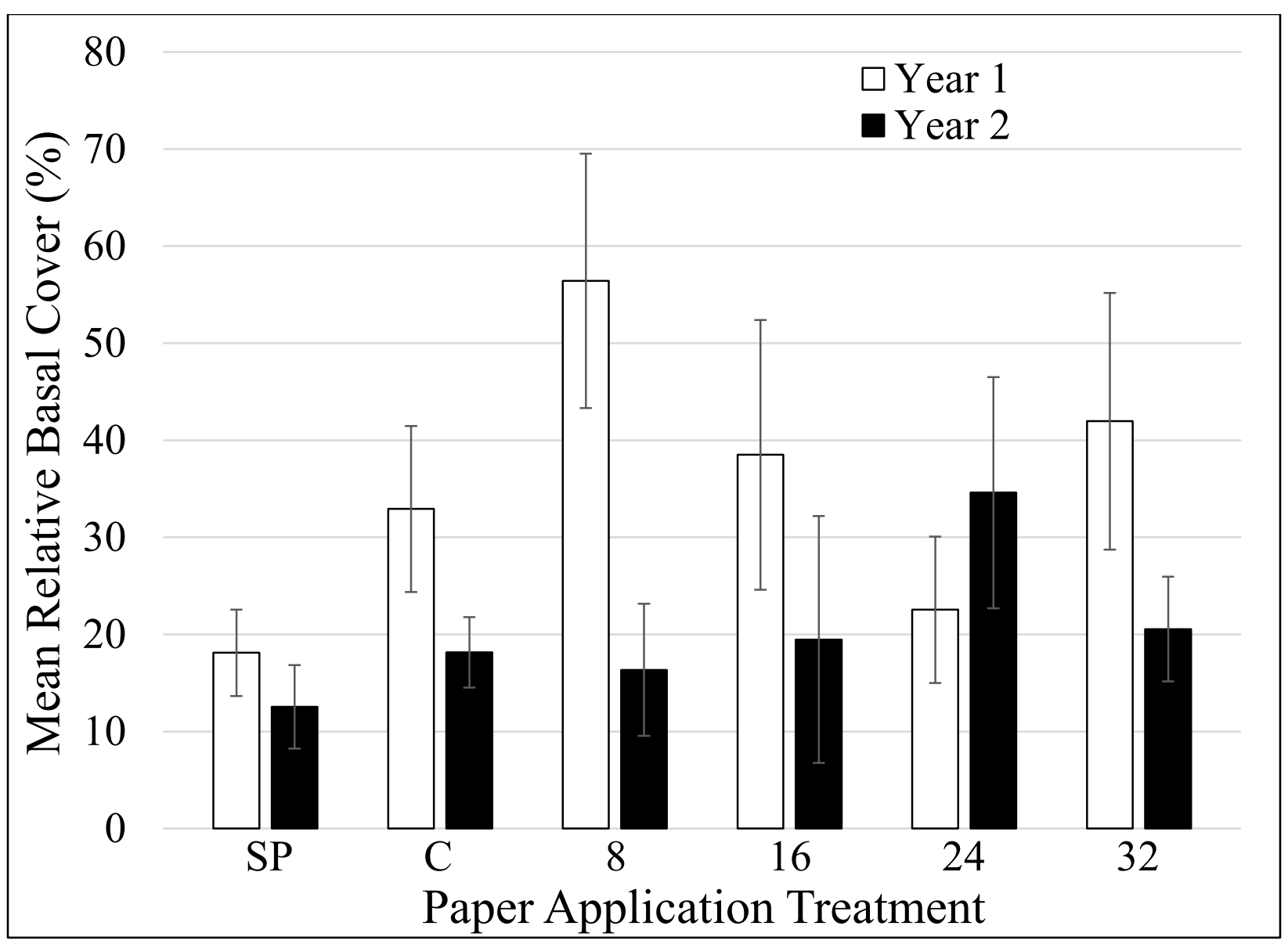

Figure 29. Mean relative planted grass basal cover at the Briley site. Means are across both years and paper application treatments. Bars are \pm 1 standard error. Treatments are as follows: $\mathrm{SP}=$ standard practice treatment, $\mathrm{C}=$ control, $8=8$ tons ac $\mathrm{ac}^{-1}$ paper, $16=16$ tons ac $\mathrm{ac}^{-1}$ paper, $24=24$ tons ac ${ }^{-1}$ paper, and $32=32$ tons ac $^{-1}$ paper.

At the Eastwood site, total basal vegetative cover did not differ between treatments in either year, although the highest paper application treatments had slightly higher mean total basal cover values (Figure 31). Mean planted grass basal cover at the Eastwood site was highest in the highest paper application rates in both years (Figure 32). Mean relative planted grass basal cover was highest in the highest paper application treatments in the first year and lowest in the standard practice treatment (Figure 33). In year 2, the 12 tons ac $^{-1}$ paper application treatment contained the highest mean relative planted grass basal cover. Mean relative weed basal cover was highest in the standard practice plots in the first year, and lowest in the 12 tons ac $\mathrm{ac}^{-1}$ treatment (Figure 34). In year 2, mean relative weed basal cover did not differ by paper application treatment, although the highest paper application treatment had a lower mean cover than both the control and standard practice treatments. 


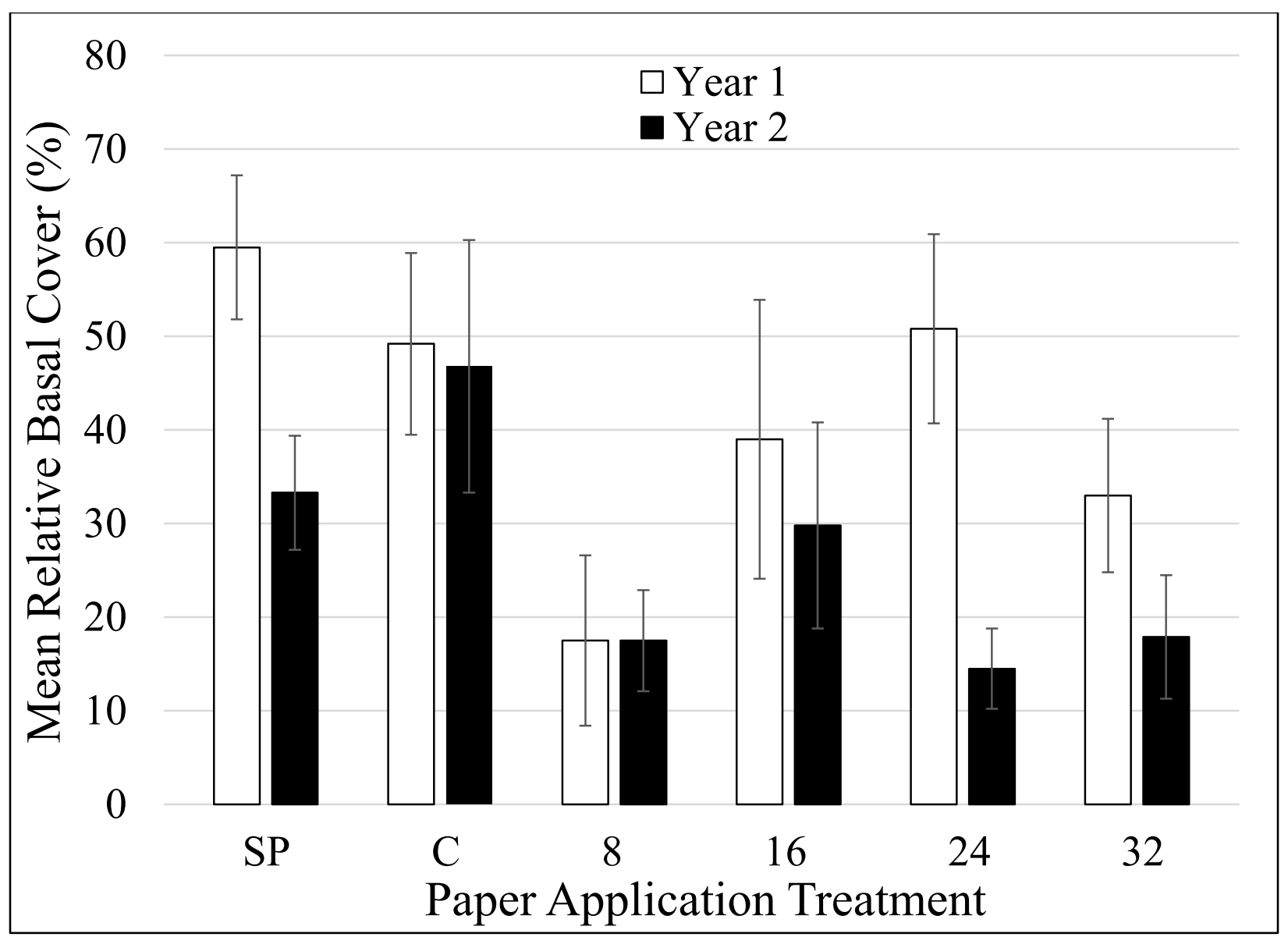

Figure 30. Mean relative weed basal cover at the Briley site. Means are across both years and paper application treatments. Bars are \pm 1 standard error. Treatments are as follows: $\mathrm{SP}=$ standard practice treatment, $\mathrm{C}=$ control, $8=8$ tons ac ${ }^{-1}$ paper, $16=16$ tons ac ${ }^{-1}$ paper, $24=24$ tons ac ${ }^{-1}$ paper, and $32=32$ tons ac $^{-1}$ paper. 


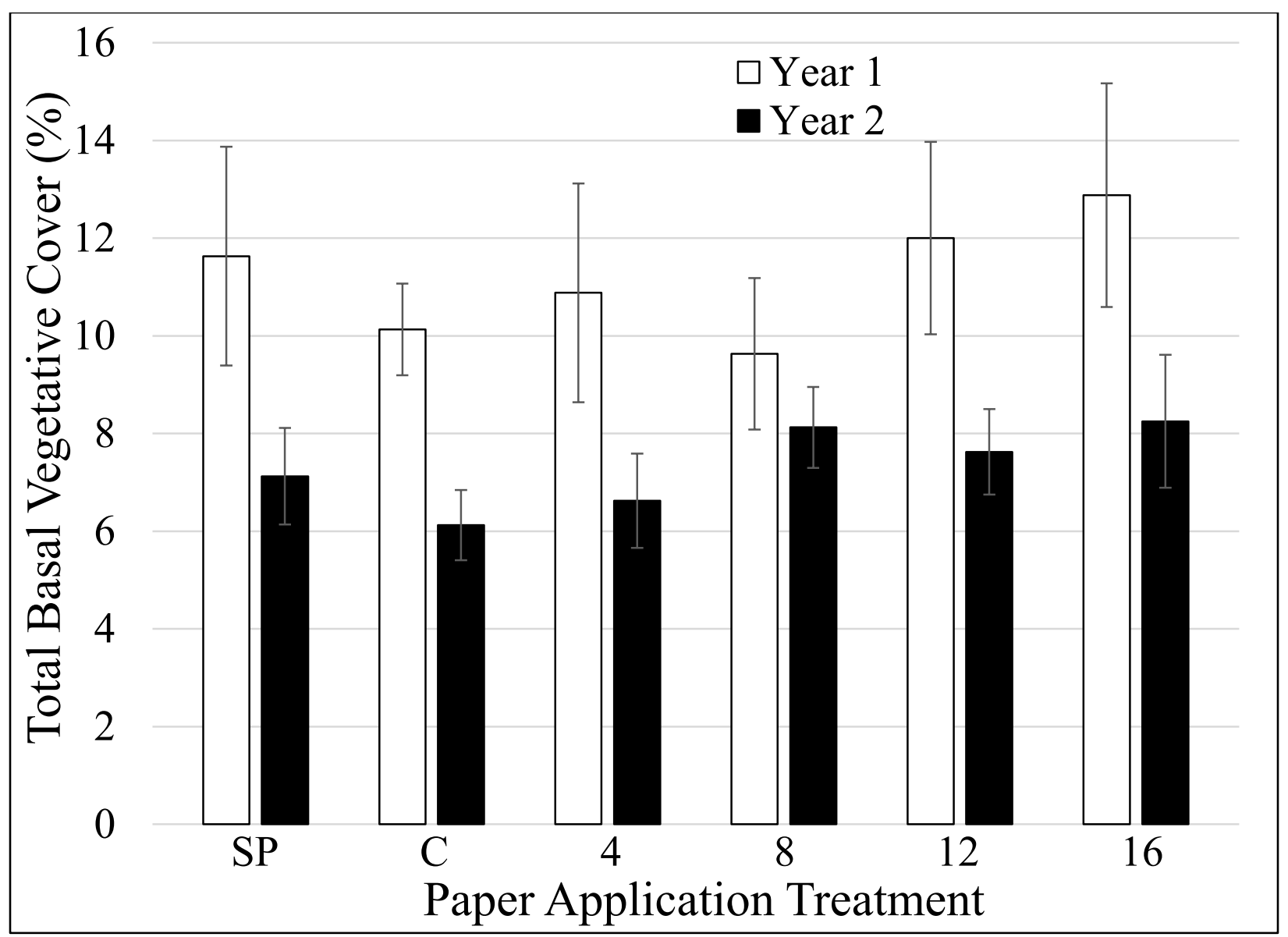

Figure 31. Mean total basal vegetative cover at the Eastwood site. Means are across both years and paper application treatments. Bars are \pm 1 standard error. Treatments are as follows: $\mathrm{SP}=$ standard practice treatment, $\mathrm{C}=$ control, $4=4$ tons ac${ }^{-1}$ paper, $8=8$ tons ac ${ }^{-1}$ paper, $12=12$ tons ac $\mathrm{ac}^{-1}$ paper, and $16=16$ tons ac $\mathrm{c}^{-1}$ paper. 


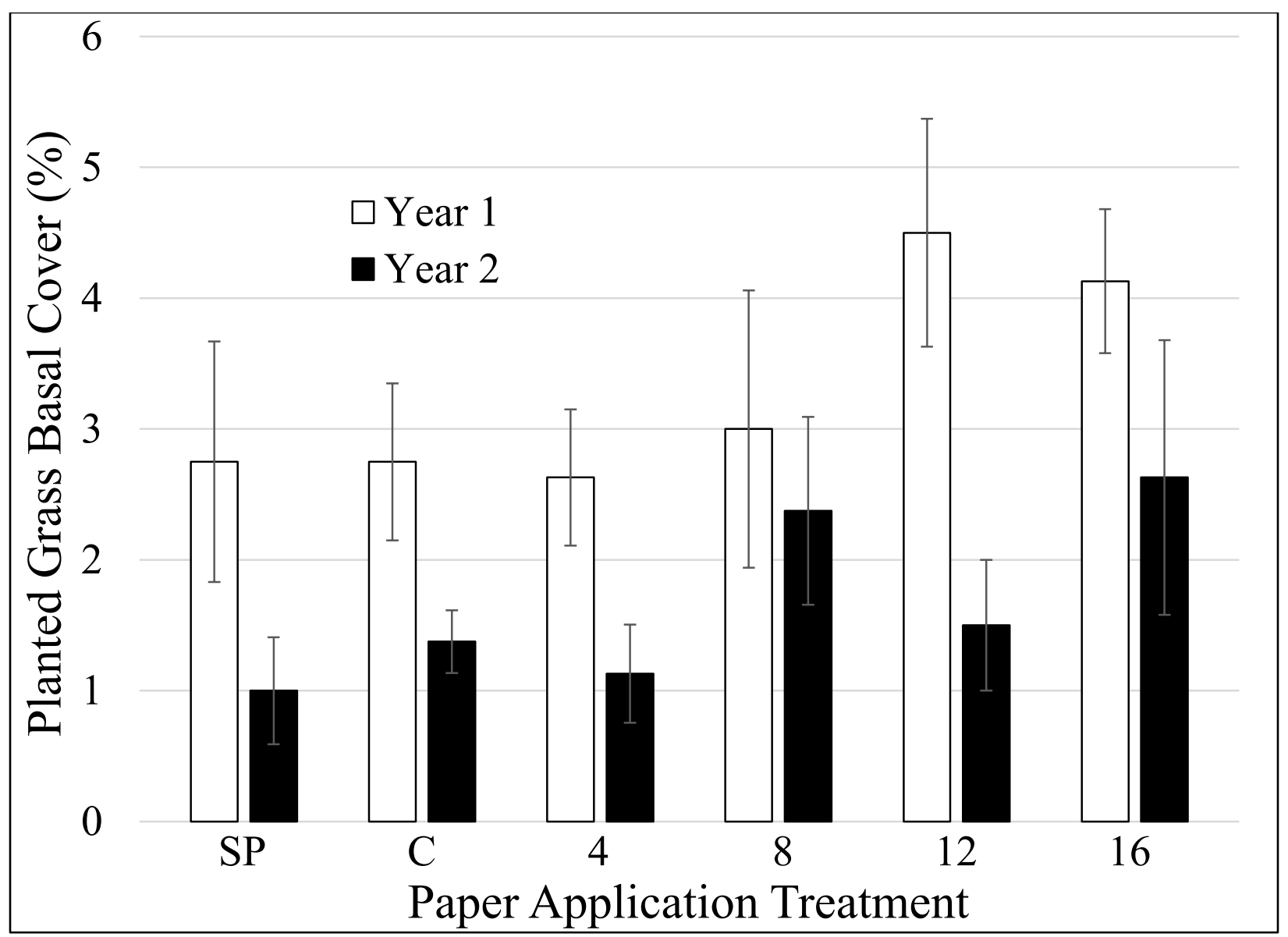

Figure 32. Mean planted grass basal cover at the Eastwood site. Means are across both years and paper application treatments. Bars are \pm 1 standard error. Treatments are as follows: $\mathrm{SP}=$ standard practice treatment, $\mathrm{C}=$ control, $4=4$ tons ac ${ }^{-1}$ paper, $8=8$ tons ac ${ }^{-1}$ paper, $12=12$ tons ac ${ }^{-1}$ paper, and $16=16$ tons ac paper. $^{-1}$ 


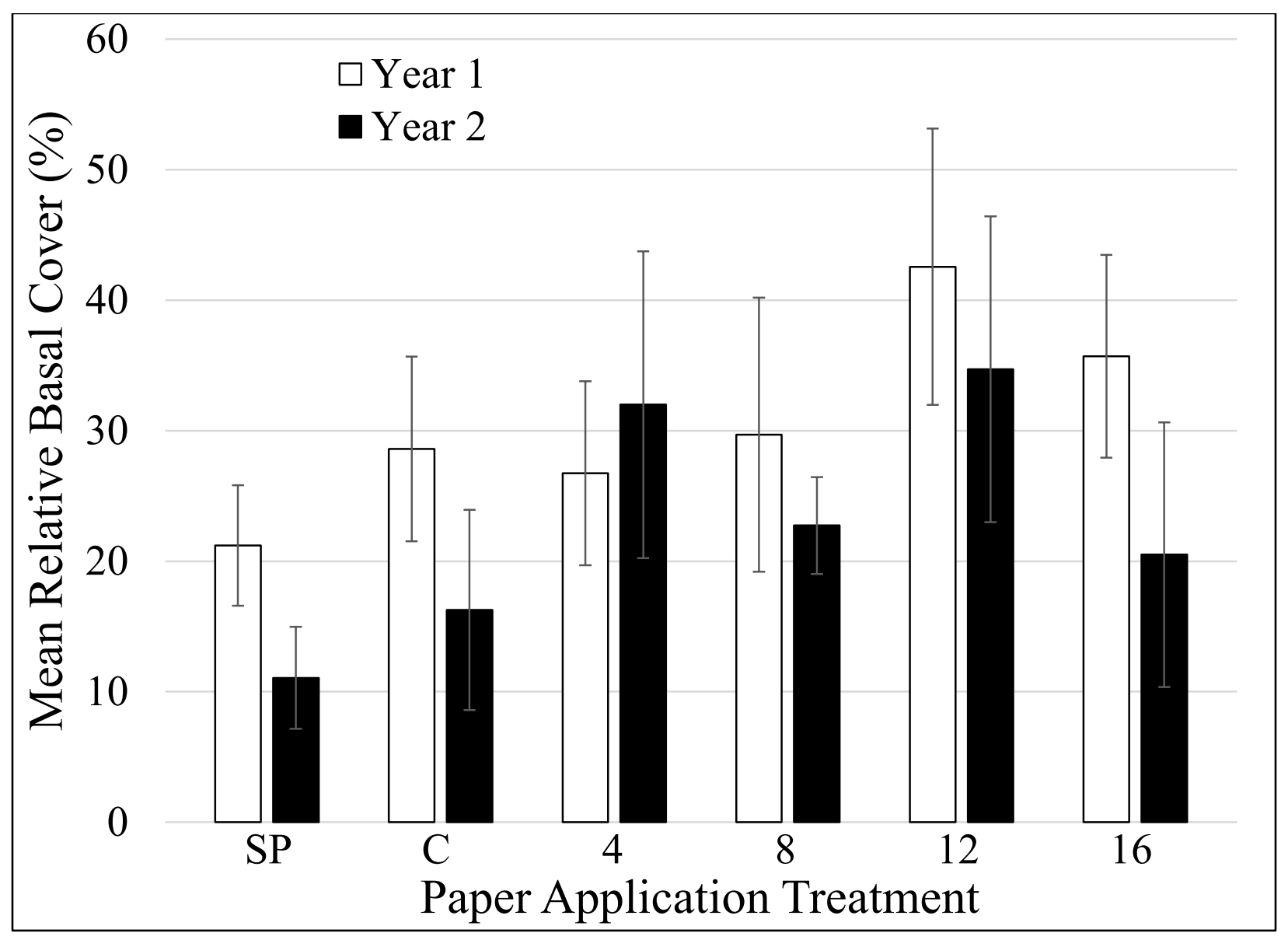

Figure 33. Mean relative planted grass basal cover at the Eastwood site. Means are across both years and paper application treatments. Bars are \pm 1 standard error. Treatments are as follows: $\mathrm{SP}=$ standard practice treatment, $\mathrm{C}=$ control, $4=4$ tons ac ${ }^{-1}$ paper, $8=8$ tons ac ${ }^{-1}$ paper, $12=12$ tons ac ${ }^{-1}$ paper, and $16=16$ tons ac $^{-1}$ paper. 


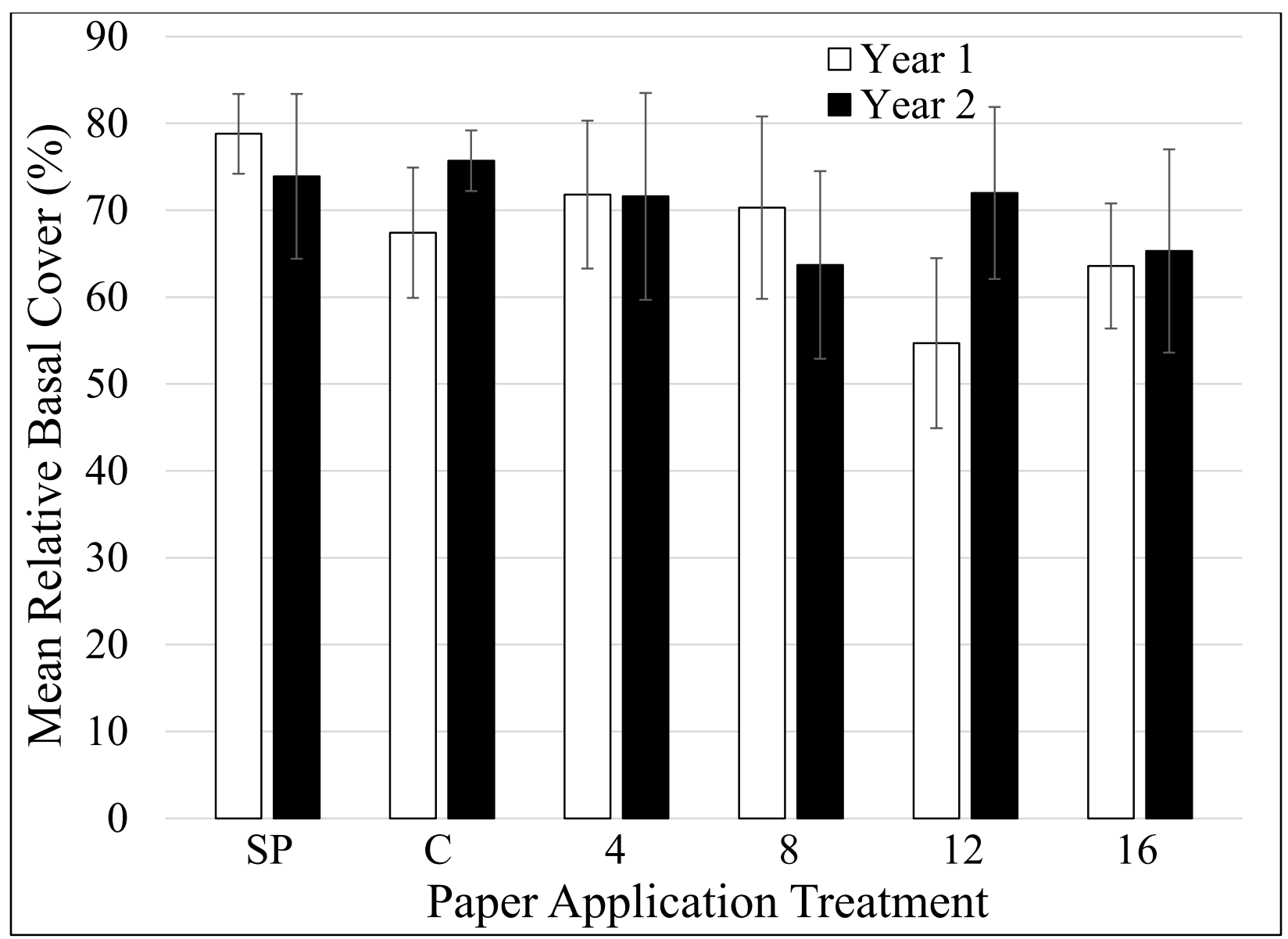

Figure 34. Mean relative weed basal cover at the Eastwood site. Means are across both years and paper application treatments. Bars are \pm 1 standard error. Treatments are as follows: $\mathrm{SP}=$ standard practice treatment, $\mathrm{C}=$ control, $4=4$ tons ac ${ }^{-1}$ paper, $8=8$ tons ac ${ }^{-1}$ paper, $12=12$ tons ac $\mathrm{ac}^{-1}$ paper, and $16=16$ tons ac ${ }^{-1}$ paper. 


\section{Plant Biomass}

Mean total plant biomass at the Briley site averaged $11.0 \mathrm{~g} \mathrm{~m}^{-2}$ in 2016 and $37.8 \mathrm{~g} \mathrm{~m}^{-2}$ in 2017 , while averaging $28.3 \mathrm{~g} \mathrm{~m}^{-2}$ in 2016 and $35.2 \mathrm{~g} \mathrm{~m}^{-2}$ in 2017 at the Eastwood site. At the Briley site, mean total biomass was highest in the standard practice treatment and decreased with increasing paper application treatment in year 1 (Figure 35). In year 2, the standard practice had the highest total biomass, while the 24 tons ac ${ }^{-1}$ treatment had the lowest. Mean relative planted grass biomass was lower in the 24 tons ac ${ }^{-1}$ treatment than all other treatments (Figure 36). In year 2, mean relative planted grass biomass was higher in the control treatment than the highest paper application treatment.

At the Eastwood site, mean total biomass was highest in the standard practice treatment and decreased with increasing paper application rate in year 1 (Figure 37). In year 2, mean total biomass was also highest in the standard practice treatment, but lowest in the 12 tons $\mathrm{ac}^{-1}$ paper treatment. Mean relative planted grass biomass at the Eastwood site was highest in the paper application treatments in both years, and increased with increasing paper application rate in year 2 (Figure 38).

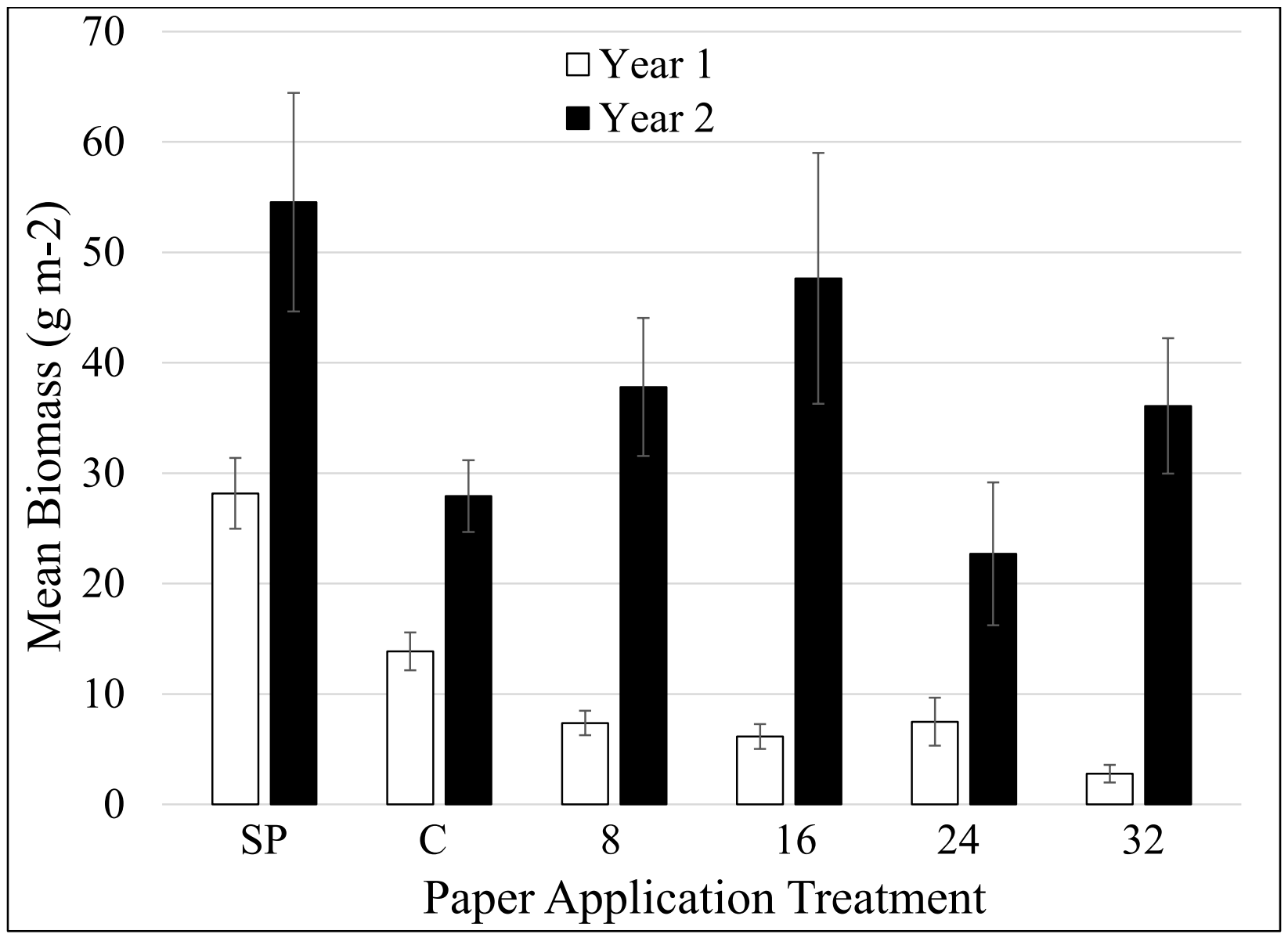

Figure 35. Mean total biomass at the Briley site. Means are across both years and paper application treatments. Bars are \pm 1 standard error. Treatments are as follows: $\mathrm{SP}=$ standard practice treatment, $\mathrm{C}=$ control, $8=8$ tons $\mathrm{ac}^{-1}$ paper, $16=16$ tons $^{-1}$ paper, $24=24$ tons $^{-1}$ paper, and $32=32$ tons $^{-1}$ paper. 


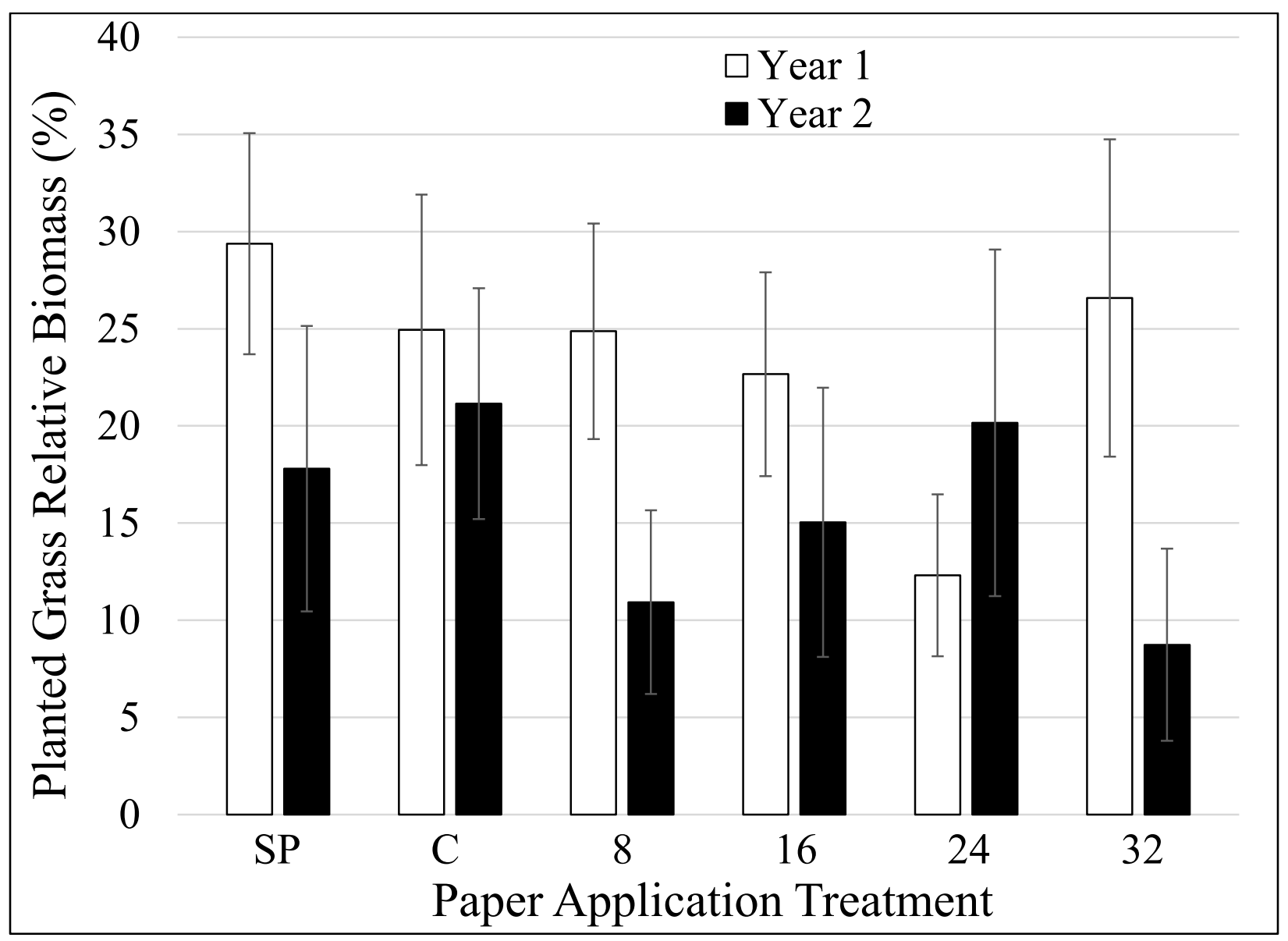

Figure 36. Mean planted grass relative biomass at the Briley site. Means are across both years and paper application treatments. Bars are \pm 1 standard error. Treatments are as follows: $\mathrm{SP}=$ standard practice treatment $\mathrm{C}=$ control, $8=8$ tons ac ${ }^{-1}$ paper, $16=16$ tons $^{-1}$ paper, $24=24$ tons $^{-1}$ paper, and $32=32$ tons $^{-1}$ paper. 


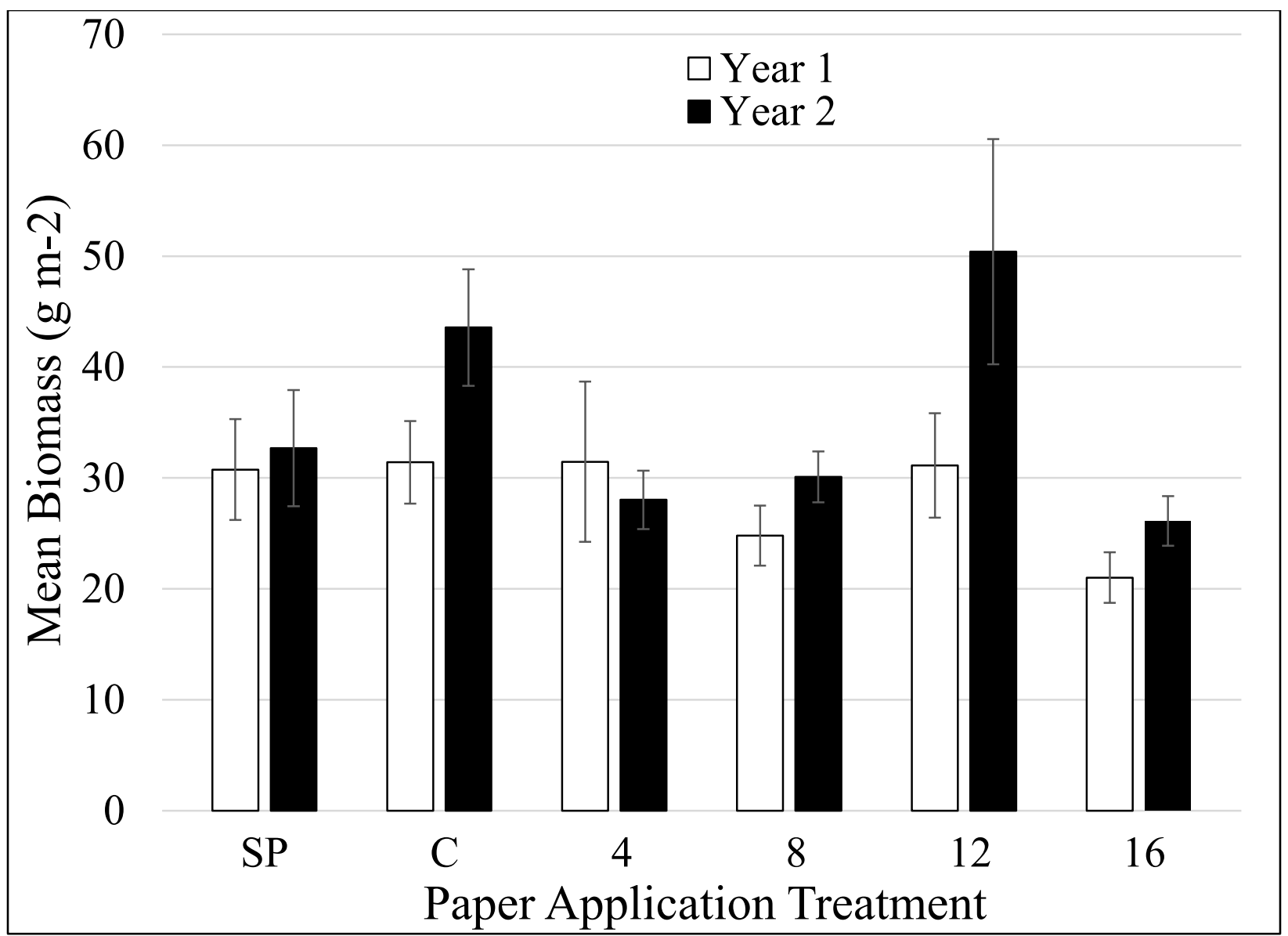

Figure 37. Mean total biomass at the Eastwood site. Means are across both years and paper application treatments. Bars are \pm 1 standard error. Treatments are as follows: $\mathrm{SP}=$ standard practice treatment, $\mathrm{C}=$ control, $4=4$ tons ac ${ }^{-1}$ paper, $8=8$ tons ac ${ }^{-1}$ paper, $12=12$ tons ac $\mathrm{ac}^{-1}$ paper, and $16=16$ tons ac $\mathrm{ac}^{-1}$ paper. 


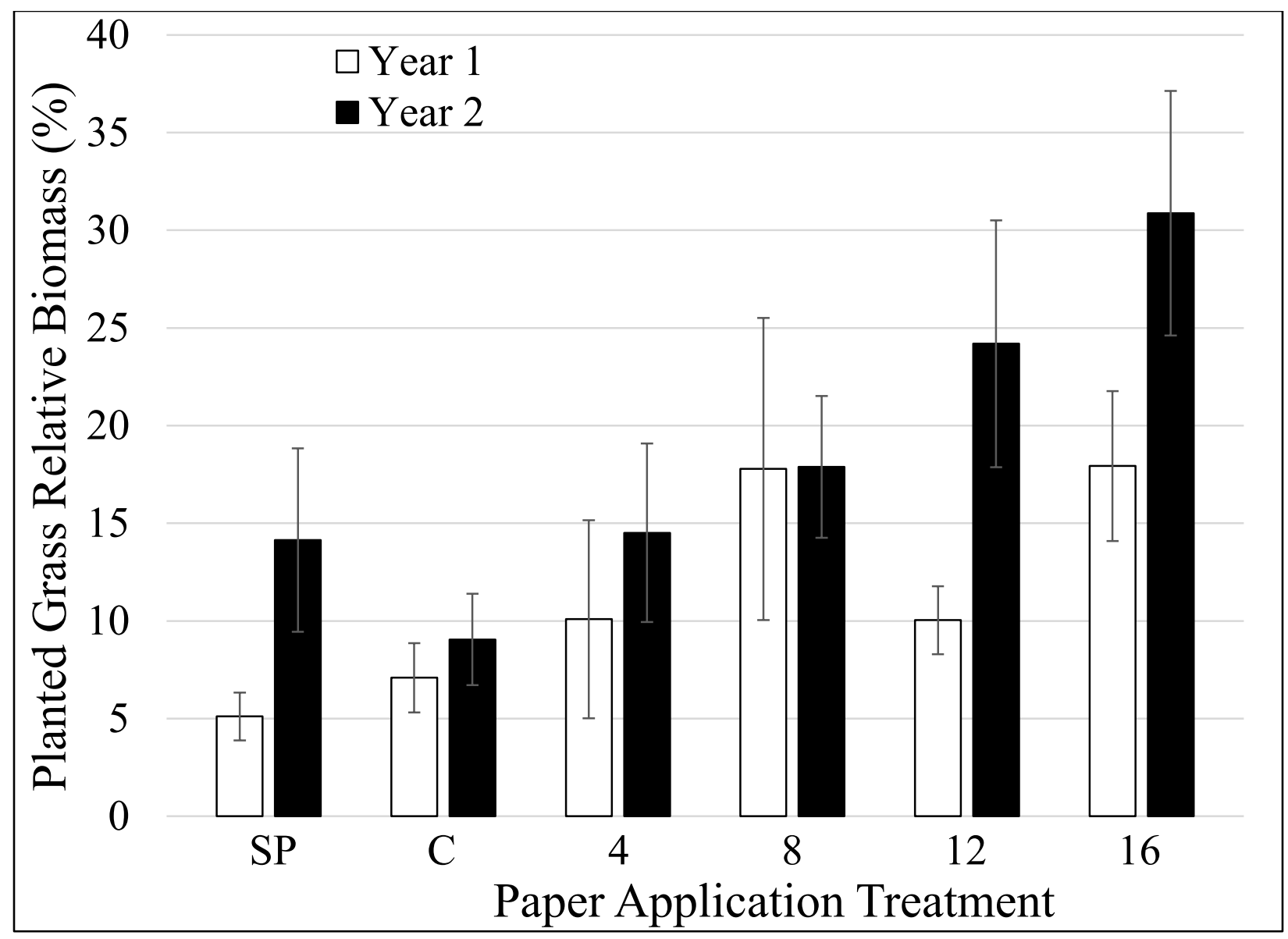

Figure 38. Mean planted grass relative biomass at the Eastwood site. Means are across both years and paper application treatments. Bars are \pm 1 standard error. Treatments are as follows: $\mathrm{SP}=$ standard practice treatment, $\mathrm{C}=$ control, $4=4$ tons ac $\mathrm{ac}^{-1}$ paper, $8=8$ tons ac $\mathrm{ac}^{-1}$ paper, $12=12$ tons ac $\mathrm{ac}^{-1}$ paper, and $16=16 \mathrm{tons}^{-1}$ paper.

\section{Plant Chemistry}

Ground biomass from a composite planted grass sample in each plot in each year was analyzed for total elemental concentrations by the Ohio Agricultural Research and Development Center STAR Lab (Wooster, OH) with an inductively coupled plasma spectrophotometer. All plant macronutrients were influenced by paper application at the Briley site in both years (Table 14). All macronutrient concentrations in planted grasses increased with increasing paper application rate, with most concentrations peaking at the 24 tons $\mathrm{ac}^{-1}$ rate. At the Eastwood site, only Ca increased with increasing paper application rate in year 1 , while $\mathrm{P}, \mathrm{Ca}$, and $\mathrm{S}$ concentrations increased with increasing paper application rate in year 2 (Table 14).

Of the plant micronutrient concentrations, B, Mo, and Al all increased with increasing paper application rate in year 1 at the Briley site, while only Mo concentrations increased with increasing application rate in year 2 (Table 15). At the Eastwood site, only Mo concentrations increased with increasing paper application rate in year 1, while Fe, Mo, and Al concentrations increased with increasing paper application rate in year 2 (Table 15). 
Table 14. Macronutrient concentrations in planted grasses. Mean concentrations are across sites, years, and paper application treatments. Values within a column followed by the same lowercase letter are not significantly different at $P<0.10$.

\begin{tabular}{|c|c|c|c|c|c|c|}
\hline \multirow{2}{*}{$\begin{array}{l}\text { Paper Application } \\
\text { Treatment }\end{array}$} & $\frac{\underline{N}}{(\%)}$ & $\underline{P}$ & $\underline{\mathrm{K}}$ & $\frac{\mathrm{Ca}}{\left(\mathrm{mg} \mathrm{kg}^{-1}\right.}$ & $\underline{\mathrm{Mg}}$ & $\underline{\mathrm{S}}$ \\
\hline & \multicolumn{6}{|c|}{ Briley Site } \\
\hline \multirow{3}{*}{$\begin{array}{c}\text { Standard Practice } \\
\text { Control }\end{array}$} & \\
\hline & \multicolumn{6}{|c|}{$\begin{array}{l}\text { Year 1 } \\
2790 \text { a }\end{array}$} \\
\hline & $0.985 \mathrm{ab}$ & $500 \mathrm{a}$ & $8190 \mathrm{ab}$ & $2480 \mathrm{a}$ & $1392 \mathrm{a}$ & $1116 \mathrm{~b}$ \\
\hline 8 tons acre ${ }^{-1}$ & $1.180 \mathrm{bc}$ & $641 \mathrm{~b}$ & $9166 \mathrm{~b}$ & $3860 \mathrm{a}$ & $1634 \mathrm{ab}$ & $1253 \mathrm{bc}$ \\
\hline 16 tons acre ${ }^{-1}$ & $1.098 \mathrm{bc}$ & $666 \mathrm{~b}$ & $9219 b c$ & $4222 \mathrm{ab}$ & $1842 \mathrm{~b}$ & $1237 \mathrm{bc}$ \\
\hline 24 tons acre ${ }^{-1}$ & $1.339 \mathrm{c}$ & $753 \mathrm{~b}$ & $11034 \mathrm{c}$ & $4085 \mathrm{ab}$ & $1390 \mathrm{a}$ & $1269 \mathrm{bc}$ \\
\hline \multirow[t]{3}{*}{32 tons acre ${ }^{-1}$} & $1.152 \mathrm{bc}$ & $686 \mathrm{~b}$ & $9388 \mathrm{bc}$ & $5955 \mathrm{~b}$ & $1438 \mathrm{a}$ & $1312 \mathrm{c}$ \\
\hline & \multicolumn{6}{|c|}{ Year 2} \\
\hline & \multicolumn{6}{|c|}{ Briley Site } \\
\hline Standard Practice & $0.543 \mathrm{ab}$ & $288 \mathrm{a}$ & $3795 a$ & $2371 \mathrm{a}$ & $1177 \mathrm{a}$ & $706 a$ \\
\hline Control & $0.495 \mathrm{a}$ & $290 \mathrm{a}$ & $3833 a$ & $1792 \mathrm{a}$ & $1160 \mathrm{a}$ & $640 a$ \\
\hline 8 tons acre ${ }^{-1}$ & $0.635 \mathrm{~b}$ & $396 \mathrm{a}$ & $5221 \mathrm{a}$ & $4073 \mathrm{~b}$ & $1188 \mathrm{a}$ & $648 a$ \\
\hline 16 tons acre ${ }^{-1}$ & $0.593 \mathrm{ab}$ & $368 \mathrm{a}$ & $4032 \mathrm{a}$ & $4370 \mathrm{~b}$ & $1237 \mathrm{a}$ & $709 a$ \\
\hline 24 tons acre $^{-1}$ & $0.861 \mathrm{c}$ & $639 \mathrm{~b}$ & $7748 \mathrm{~b}$ & $5973 \mathrm{~b}$ & $1574 \mathrm{~b}$ & $990 \mathrm{~b}$ \\
\hline \multirow[t]{3}{*}{32 tons acre ${ }^{-1}$} & $0.618 \mathrm{ab}$ & $360 \mathrm{a}$ & $3766 \mathrm{a}$ & $2739 a b$ & $956 \mathrm{a}$ & $774 \mathrm{ab}$ \\
\hline & \multicolumn{6}{|c|}{ Eastwood Site } \\
\hline & \multicolumn{6}{|c|}{ Year 1} \\
\hline Standard Practice & $1.068 \mathrm{~b}$ & $1132 \mathrm{ab}$ & 9915 a & 4409 a & $1903 \mathrm{a}$ & $1040 \mathrm{a}$ \\
\hline Control & $0.908 \mathrm{a}$ & $922 \mathrm{a}$ & $10529 \mathrm{a}$ & $4610 \mathrm{ab}$ & $2145 a b$ & 990 a \\
\hline 4 tons acre ${ }^{-1}$ & $0.883 \mathrm{a}$ & $1463 \mathrm{~b}$ & $11281 \mathrm{a}$ & $5076 \mathrm{~b}$ & $2206 \mathrm{~b}$ & 1099 a \\
\hline 8 tons acre ${ }^{-1}$ & $0.945 \mathrm{ab}$ & $1424 \mathrm{~b}$ & $10157 \mathrm{a}$ & $5896 \mathrm{c}$ & $2206 \mathrm{~b}$ & 931 a \\
\hline 12 tons acre ${ }^{-1}$ & $0.920 \mathrm{a}$ & $1213 \mathrm{ab}$ & $10283 \mathrm{a}$ & $5537 \mathrm{bc}$ & 2099 a & $959 a$ \\
\hline \multirow[t]{2}{*}{16 tons acre ${ }^{-1}$} & $0.900 \mathrm{a}$ & $1363 \mathrm{~b}$ & $9125 \mathrm{a}$ & $6934 \mathrm{~d}$ & $1987 \mathrm{ab}$ & 961 a \\
\hline & \multicolumn{6}{|c|}{ Year 2} \\
\hline Standard Practice & $0.800 \mathrm{ab}$ & $992 \mathrm{ab}$ & $11082 \mathrm{a}$ & $4066 \mathrm{~b}$ & $1554 \mathrm{a}$ & $791 a$ \\
\hline Control & $0.808 \mathrm{ab}$ & $872 \mathrm{a}$ & $11186 \mathrm{a}$ & $3198 \mathrm{a}$ & $1547 \mathrm{a}$ & $699 a$ \\
\hline 4 tons acre ${ }^{-1}$ & $0.708 \mathrm{a}$ & $1109 \mathrm{ab}$ & $9588 \mathrm{a}$ & $3324 a b$ & $1274 \mathrm{a}$ & $792 a$ \\
\hline 8 tons acre $e^{-1}$ & $0.825 \mathrm{ab}$ & $1283 \mathrm{ab}$ & 10587 a & $5022 \mathrm{bc}$ & $1502 \mathrm{a}$ & $882 \mathrm{~b}$ \\
\hline 12 tons acre ${ }^{-1}$ & $0.735 \mathrm{ab}$ & $1262 \mathrm{ab}$ & $8590 \mathrm{a}$ & $4691 \mathrm{bc}$ & $1400 \mathrm{a}$ & $763 a$ \\
\hline 16 tons acre ${ }^{-1}$ & $0.855 \mathrm{~b}$ & $1380 \mathrm{~b}$ & $10149 \mathrm{a}$ & $5606 \mathrm{c}$ & $1313 \mathrm{a}$ & $894 \mathrm{~b}$ \\
\hline
\end{tabular}


Table 15. Micronutrient concentrations in planted grasses. Mean concentrations are across sites, years, and paper application treatments. Values within a column followed by the same lowercase letter are not significantly different at $P<0.10$.

\begin{tabular}{|c|c|c|c|c|c|c|c|c|}
\hline & \multicolumn{8}{|c|}{$\left(\mathrm{mg} \mathrm{kg}^{-1}\right)$} \\
\hline \multicolumn{9}{|c|}{ Briley Site } \\
\hline $\begin{array}{c}\text { Paper } \\
\text { Application } \\
\text { Treatment }\end{array}$ & & & & \multicolumn{3}{|c|}{ Year 1} & & \\
\hline $\begin{array}{l}\text { Standard } \\
\text { Practice }\end{array}$ & $69.78 \mathrm{a}$ & $88.50 \mathrm{a}$ & $29.55 \mathrm{ab}$ & $3.13 \mathrm{a}$ & $3.00 \mathrm{a}$ & $0.447 \mathrm{ab}$ & $257.3 \mathrm{~b}$ & $54.68 \mathrm{a}$ \\
\hline Control & $140.45 \mathrm{ab}$ & $98.03 \mathrm{a}$ & $37.76 \mathrm{~b}$ & $4.74 \mathrm{a}$ & $3.93 \mathrm{a}$ & $0.193 \mathrm{a}$ & $254.8 \mathrm{~b}$ & $156.56 \mathrm{ab}$ \\
\hline 8 tons acre ${ }^{-1}$ & $199.51 \mathrm{~b}$ & $81.95 \mathrm{a}$ & $31.80 \mathrm{ab}$ & $11.38 \mathrm{ab}$ & $4.01 \mathrm{a}$ & $0.190 \mathrm{a}$ & $107.5 \mathrm{a}$ & $216.59 \mathrm{~b}$ \\
\hline 16 tons acre ${ }^{-1}$ & $118.35 \mathrm{a}$ & $104.80 \mathrm{a}$ & $36.95 \mathrm{~b}$ & $6.38 \mathrm{a}$ & $3.84 \mathrm{a}$ & $0.308 \mathrm{a}$ & $113.1 \mathrm{a}$ & $130.05 \mathrm{ab}$ \\
\hline 24 tons acre ${ }^{-1}$ & $137.80 \mathrm{ab}$ & $105.05 \mathrm{a}$ & $34.51 \mathrm{~b}$ & $22.32 \mathrm{~b}$ & $4.10 \mathrm{a}$ & $0.519 \mathrm{ab}$ & $141.1 \mathrm{ab}$ & $129.85 \mathrm{ab}$ \\
\hline 32 tons acre ${ }^{-1}$ & \multicolumn{8}{|c|}{ Year 2} \\
\hline $\begin{array}{l}\text { Standard } \\
\text { Practice }\end{array}$ & $153.2 \mathrm{a}$ & $137.08 \mathrm{a}$ & $24.40 \mathrm{a}$ & $2.72 \mathrm{a}$ & $3.74 \mathrm{a}$ & $0.197 \mathrm{ab}$ & $130.98 \mathrm{a}$ & $80.03 \mathrm{a}$ \\
\hline Control & $219.5 \mathrm{a}$ & $86.93 \mathrm{a}$ & $19.88 \mathrm{a}$ & $3.81 \mathrm{a}$ & $5.39 \mathrm{a}$ & $0.117 \mathrm{a}$ & $165.15 \mathrm{a}$ & $132.75 \mathrm{a}$ \\
\hline 8 tons acre ${ }^{-1}$ & $206.5 \mathrm{a}$ & $58.85 \mathrm{a}$ & $25.80 \mathrm{a}$ & $3.04 \mathrm{a}$ & $4.09 \mathrm{a}$ & $0.404 \mathrm{ab}$ & $140.60 \mathrm{a}$ & $119.13 \mathrm{a}$ \\
\hline 16 tons acre ${ }^{-1}$ & $163.5 \mathrm{a}$ & $77.75 \mathrm{a}$ & $25.29 \mathrm{a}$ & $3.72 \mathrm{a}$ & $3.32 \mathrm{a}$ & $1.285 \mathrm{~b}$ & $141.56 \mathrm{a}$ & $101.23 \mathrm{a}$ \\
\hline 24 tons acre ${ }^{-1}$ & $197.8 \mathrm{a}$ & $87.55 \mathrm{a}$ & $25.62 \mathrm{a}$ & $3.97 \mathrm{a}$ & $4.75 \mathrm{a}$ & $0.940 \mathrm{~b}$ & $85.82 \mathrm{a}$ & $166.15 \mathrm{a}$ \\
\hline 32 tons acre ${ }^{-1}$ & $213.8 \mathrm{a}$ & $119.65 \mathrm{a}$ & $23.20 \mathrm{a}$ & $2.49 \mathrm{a}$ & $2.86 \mathrm{a}$ & $1.101 \mathrm{~b}$ & $103.55 \mathrm{a}$ & $108.13 \mathrm{a}$ \\
\hline \multicolumn{9}{|c|}{ Eastwood Site } \\
\hline & \multicolumn{8}{|c|}{ Year 1} \\
\hline $\begin{array}{l}\text { Standard } \\
\text { Practice }\end{array}$ & $187.13 \mathrm{a}$ & $168.53 \mathrm{bc}$ & $69.14 \mathrm{~b}$ & $2.67 \mathrm{a}$ & $4.02 \mathrm{~b}$ & $0.221 \mathrm{a}$ & $52.8 \mathrm{a}$ & $144.10 \mathrm{a}$ \\
\hline Control & $145.28 \mathrm{a}$ & $184.63 \mathrm{c}$ & $96.13 \mathrm{c}$ & $3.08 \mathrm{ab}$ & $3.77 \mathrm{~b}$ & $0.281 \mathrm{a}$ & $52.6 \mathrm{a}$ & $175.35 \mathrm{a}$ \\
\hline 4 tons acre ${ }^{-1}$ & $177.38 \mathrm{a}$ & $125.30 \mathrm{ab}$ & $36.72 \mathrm{a}$ & $6.59 \mathrm{~b}$ & $3.41 \mathrm{ab}$ & $1.150 \mathrm{ab}$ & $88.9 \mathrm{~b}$ & $180.15 \mathrm{a}$ \\
\hline 8 tons acre ${ }^{-1}$ & $124.58 \mathrm{a}$ & $106.33 \mathrm{a}$ & $31.96 \mathrm{a}$ & $2.85 \mathrm{a}$ & $3.60 \mathrm{ab}$ & $1.486 \mathrm{~b}$ & $53.3 \mathrm{a}$ & $115.33 \mathrm{a}$ \\
\hline 12 tons acre ${ }^{-1}$ & $121.68 \mathrm{a}$ & $92.15 \mathrm{a}$ & $40.97 \mathrm{a}$ & $3.59 \mathrm{ab}$ & $3.51 \mathrm{ab}$ & $1.638 \mathrm{bc}$ & $55.5 \mathrm{a}$ & $130.98 \mathrm{a}$ \\
\hline 16 tons acre ${ }^{-1}$ & \multicolumn{8}{|c|}{ Year 2} \\
\hline $\begin{array}{l}\text { Standard } \\
\text { Practice }\end{array}$ & $98.43 \mathrm{a}$ & $121.33 \mathrm{~b}$ & $47.97 \mathrm{~b}$ & $3.57 \mathrm{a}$ & $9.86 \mathrm{a}$ & $0.155 \mathrm{a}$ & $66.07 \mathrm{ab}$ & $54.13 \mathrm{a}$ \\
\hline Control & $148.13 \mathrm{~b}$ & $197.28 \mathrm{c}$ & $53.71 \mathrm{~b}$ & $2.57 \mathrm{a}$ & $5.01 \mathrm{a}$ & $0.103 \mathrm{a}$ & $76.16 \mathrm{ab}$ & $35.20 \mathrm{a}$ \\
\hline 4 tons acre ${ }^{-1}$ & $105.50 \mathrm{ab}$ & $104.33 \mathrm{ab}$ & $28.35 \mathrm{a}$ & $3.59 \mathrm{a}$ & $7.43 \mathrm{a}$ & $0.425 \mathrm{ab}$ & $65.64 \mathrm{ab}$ & $48.55 \mathrm{a}$ \\
\hline 8 tons acre ${ }^{-1}$ & $116.85 \mathrm{abc}$ & $87.98 \mathrm{ab}$ & $26.99 \mathrm{a}$ & $2.30 \mathrm{a}$ & $8.88 \mathrm{a}$ & $1.191 \mathrm{bc}$ & $48.82 \mathrm{a}$ & $42.98 \mathrm{a}$ \\
\hline 12 tons acre ${ }^{-1}$ & $132.05 \mathrm{abc}$ & $74.18 \mathrm{a}$ & $34.73 \mathrm{a}$ & $1.42 \mathrm{a}$ & $6.42 \mathrm{a}$ & $1.295 \mathrm{c}$ & $116.31 \mathrm{~b}$ & $57.50 \mathrm{a}$ \\
\hline 16 tons acre ${ }^{-1}$ & $166.00 \mathrm{c}$ & $86.38 \mathrm{ab}$ & $25.58 \mathrm{a}$ & $4.69 \mathrm{a}$ & $6.07 \mathrm{a}$ & $1.452 \mathrm{c}$ & $87.20 \mathrm{a}$ & $90.85 \mathrm{~b}$ \\
\hline
\end{tabular}




\section{Soils}

Soil total elemental concentrations were analyzed by the Ohio Agricultural Research and Development Center STAR Lab (Wooster, OH) with an inductively coupled plasma spectrophotometer. Soil extractable elements were analyzed by the Auburn University soil testing laboratory (Auburn, AL). Most soil properties were unaffected by paper application, particularly metal concentrations. Some properties differed between treatments but appear to be a result of variations in soils across the demonstration sites. However, some significant relationships between soil properties and paper application rate were observed, especially in the second year of the demonstration.

At the Briley site, bulk density, Ca concentration and content, extractable $\mathrm{Ca}$, and $\mathrm{pH}$ were all affected by treatments in both years, while $\mathrm{C}$ concentration and content, $\mathrm{S}$ concentration, extractable $\mathrm{P}$ and $\mathrm{Mg}$, and cation exchange capacity (CEC) were only affected by treatment in year 2. In year 1, bulk density was lower in all paper application rates than the control treatment, but the lowest bulk density occurred in the 16 tons acre a $^{-1}$ paper application treatment (Table 16). This was likely a result of the higher paper application rates not achieving full incorporation into the soil. However, by year 2, bulk density decreased as paper application rate increased (Table 9). In the low paper application rates, bulk density increased slightly from year 1 to year 2 while decreasing from year 1 to year 2 in the highest rates, indicating that decomposition in the lower rates was likely occurring and unincorporated paper in the highest rates were still influencing soil properties after 2 years. Calcium concentration and content (Table 16) and extractable calcium (Table 22) in year 1 was mostly a result of liming in the standard practice treatment, which added the equivalent of 1 ton acre ${ }^{-1}$ of calcium carbonate. However in year 2 calcium concentration and content (Table 19) and extractable calcium (Table 22) all increased with increasing paper application rate (Tables 19 and 22). Soil $\mathrm{pH}$ was highest in the standard practice treatment in year 1 due to liming, but increased with increasing paper application rate in year 2 (Table 22). In year 2, soil C concentration and content (Table 19), S concentration (Table 19), extractable P and Mg (Table 19), and CEC (Table 22) all increased with increasing paper application rate. At the Eastwood site, $\mathrm{Ca}$ concentration and content were also affected by treatment in both years, while $\mathrm{pH}$ and extractable $\mathrm{Ca}$ and $\mathrm{Mg}$ were affected in year 2 only. In year 1, Ca concentration and content were higher in the standard practice treatment due to liming (Table 16), but both increased with increasing paper application rate in year 2 (Table 19), while soil $\mathrm{pH}$ and extractable $\mathrm{P}$ and $\mathrm{Ca}$ were all highest in the high paper application treatments (Table 22). 
Table 16. Soil bulk density and concentration and content of $\mathrm{C}$ and plant macronutrients at $0-20$ $\mathrm{cm}$ depth in year $1 \uparrow$.

\begin{tabular}{|c|c|c|c|c|c|c|c|c|}
\hline$\frac{\text { Paper Application }}{\underline{\text { Rate }}}$ & $\underline{\text { Bulk }}$ & $\underline{\mathrm{C}}$ & $\underline{\mathrm{N}}$ & $\frac{\underline{P}}{\text { Briley Site }}$ & $\underline{\mathrm{K}}$ & $\underline{\mathrm{Ca}}$ & $\underline{\mathrm{Mg}}$ & $\underline{\mathrm{S}}$ \\
\hline & & \multicolumn{2}{|c|}{--------- $(\%)$---------- } & \multicolumn{5}{|c|}{ 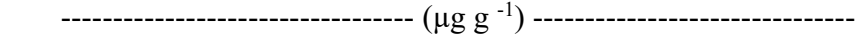 } \\
\hline Standard Practice & $1.30 \mathrm{bc}$ & $0.87 \mathrm{a}$ & $0.055 \mathrm{ab}$ & $89.81 \mathrm{a}$ & $294.4 \mathrm{a}$ & $1718 \mathrm{bc}$ & $213.7 \mathrm{a}$ & $98.03 \mathrm{a}$ \\
\hline Control & $1.35 \mathrm{c}$ & $0.99 \mathrm{a}$ & $0.060 \mathrm{ab}$ & $79.93 \mathrm{a}$ & $246.2 \mathrm{a}$ & $679 \mathrm{ab}$ & $185.0 \mathrm{a}$ & $67.39 \mathrm{a}$ \\
\hline 8 tons acre ${ }^{-1}$ & $1.11 \mathrm{ab}$ & $1.44 \mathrm{~b}$ & $0.083 \mathrm{c}$ & $84.63 \mathrm{a}$ & $595.1 \mathrm{a}$ & $2066 \mathrm{c}$ & $497.1 \mathrm{a}$ & $91.55 \mathrm{a}$ \\
\hline 16 tons acre ${ }^{-1}$ & $1.00 \mathrm{a}$ & $0.86 \mathrm{a}$ & $0.047 \mathrm{a}$ & $74.82 \mathrm{a}$ & $247.6 \mathrm{a}$ & $1040 \mathrm{abc}$ & $168.1 \mathrm{a}$ & $78.77 \mathrm{a}$ \\
\hline 24 tons acre ${ }^{-1}$ & $1.22 \mathrm{abc}$ & $0.99 \mathrm{a}$ & $0.073 \mathrm{bc}$ & $73.49 \mathrm{a}$ & $456.3 \mathrm{a}$ & $1023 \mathrm{abc}$ & $383.9 \mathrm{a}$ & $73.86 \mathrm{a}$ \\
\hline 32 tons acre ${ }^{-1}$ & $1.15 \mathrm{abc}$ & $0.91 \mathrm{a}$ & $0.060 \mathrm{ab}$ & $\begin{array}{c}86.68 \mathrm{a} \\
\text { Content }\end{array}$ & $680.8 \mathrm{a}$ & $436 \mathrm{a}$ & $586.1 \mathrm{a}$ & $76.42 \mathrm{a}$ \\
\hline & & \multicolumn{7}{|c|}{---------- $\left(\mathrm{g} \mathrm{m}^{-2}\right)$---------- } \\
\hline Standard Practice & & $23.11 \mathrm{ab}$ & $1.468 \mathrm{ab}$ & $235 \mathrm{~b}$ & $770 \mathrm{a}$ & $4411 b$ & $562 \mathrm{a}$ & $254 \mathrm{a}$ \\
\hline Control & & $26.18 \mathrm{ab}$ & $1.620 \mathrm{~b}$ & $214 \mathrm{ab}$ & $664 \mathrm{a}$ & $1758 \mathrm{ab}$ & $493 \mathrm{a}$ & $178 \mathrm{a}$ \\
\hline 8 tons acre ${ }^{-1}$ & & $31.82 \mathrm{~b}$ & $1.885 \mathrm{~b}$ & $189 \mathrm{ab}$ & $974 \mathrm{a}$ & $4645 \mathrm{ab}$ & $785 \mathrm{a}$ & $210 \mathrm{a}$ \\
\hline 16 tons acre ${ }^{-1}$ & & $15.68 \mathrm{a}$ & $0.935 \mathrm{a}$ & $146 \mathrm{a}$ & $496 \mathrm{a}$ & $1637 \mathrm{ab}$ & $346 \mathrm{a}$ & $145 \mathrm{a}$ \\
\hline 24 tons acre ${ }^{-1}$ & & $24.17 \mathrm{ab}$ & $1.783 \mathrm{~b}$ & $175 \mathrm{ab}$ & 1098 a & $2294 \mathrm{ab}$ & $925 \mathrm{a}$ & $175 \mathrm{a}$ \\
\hline \multicolumn{9}{|c|}{$\underline{\text { Eastwood Site }}$} \\
\hline \multicolumn{9}{|c|}{ Concentration } \\
\hline & & \multicolumn{2}{|c|}{-------- $(\%)$--------- } & \multicolumn{5}{|c|}{ 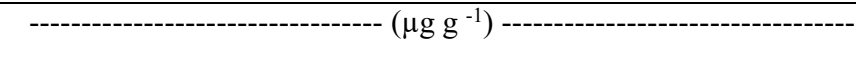 } \\
\hline Standard Practice & $1.02 \mathrm{a}$ & $1.28 \mathrm{a}$ & $0.068 \mathrm{a}$ & $39.16 \mathrm{a}$ & $274.8 \mathrm{a}$ & $3890 \mathrm{~b}$ & $410.4 \mathrm{a}$ & $107.46 \mathrm{a}$ \\
\hline Control & $1.06 \mathrm{a}$ & $1.52 \mathrm{a}$ & $0.075 \mathrm{a}$ & $48.58 \mathrm{a}$ & $442.8 \mathrm{ab}$ & $1691 \mathrm{a}$ & $664.8 \mathrm{ab}$ & $92.74 \mathrm{a}$ \\
\hline 4 tons acre ${ }^{-1}$ & $1.17 \mathrm{a}$ & $1.16 \mathrm{a}$ & $0.059 \mathrm{a}$ & $49.29 \mathrm{a}$ & $544.0 \mathrm{~b}$ & $1890 \mathrm{a}$ & $764.5 \mathrm{~b}$ & $95.10 \mathrm{a}$ \\
\hline 8 tons acre ${ }^{-1}$ & $1.21 \mathrm{a}$ & $1.31 \mathrm{a}$ & $0.075 \mathrm{a}$ & $46.27 \mathrm{a}$ & $385.5 \mathrm{ab}$ & $1933 \mathrm{a}$ & $575.5 \mathrm{ab}$ & $92.51 \mathrm{a}$ \\
\hline 12 tons acre ${ }^{-1}$ & $1.12 \mathrm{a}$ & $1.78 \mathrm{a}$ & $0.093 \mathrm{a}$ & $48.13 \mathrm{a}$ & $579.2 \mathrm{~b}$ & $1774 \mathrm{a}$ & $837.3 \mathrm{~b}$ & $86.55 \mathrm{a}$ \\
\hline 16 tons acre ${ }^{-1}$ & $1.28 \mathrm{a}$ & $1.32 \mathrm{a}$ & $0.065 \mathrm{a}$ & $\begin{array}{l}37.49 \mathrm{a} \\
\text { Content }\end{array}$ & $332.2 \mathrm{a}$ & $1255 \mathrm{a}$ & $421.4 \mathrm{ab}$ & $64.85 \mathrm{a}$ \\
\hline & & \multicolumn{7}{|c|}{ - $\left(\mathrm{g} \mathrm{m}^{-2}\right)$ - - } \\
\hline Standard Practice & & $24.03 \mathrm{a}$ & $1.373 \mathrm{a}$ & $81 \mathrm{a}$ & 578 a & $8106 \mathrm{~b}$ & $863 \mathrm{a}$ & $224 \mathrm{a}$ \\
\hline Control & & $33.91 \mathrm{a}$ & $1.705 \mathrm{a}$ & $112 \mathrm{a}$ & $1017 \mathrm{ab}$ & $3561 \mathrm{ab}$ & $1522 \mathrm{ab}$ & $210 \mathrm{a}$ \\
\hline 4 tons acre ${ }^{-1}$ & & $26.41 \mathrm{a}$ & $1.380 \mathrm{a}$ & $112 \mathrm{a}$ & $1255 \mathrm{~b}$ & $3985 \mathrm{ab}$ & $1770 \mathrm{~b}$ & $208 \mathrm{a}$ \\
\hline 8 tons acre ${ }^{-1}$ & & $32.38 \mathrm{a}$ & $1.810 \mathrm{a}$ & $111 \mathrm{a}$ & $895 \mathrm{ab}$ & $4264 a b$ & $1354 \mathrm{ab}$ & $216 \mathrm{a}$ \\
\hline 12 tons acre ${ }^{-1}$ & & $40.94 \mathrm{a}$ & $1.998 \mathrm{a}$ & $112 \mathrm{a}$ & 1298 b & $3991 \mathrm{ab}$ & 1892 b & $206 \mathrm{a}$ \\
\hline 16 tons acre $^{-1}$ & & $33.49 \mathrm{a}$ & $1.653 \mathrm{a}$ & $95 \mathrm{a}$ & $849 a b$ & $3136 \mathrm{a}$ & $1066 \mathrm{a}$ & $162 \mathrm{a}$ \\
\hline
\end{tabular}


Table 17. Soil concentration and content of plant micronutrients at $0-20 \mathrm{~cm}$ depth in year $1 \uparrow$.

\begin{tabular}{|c|c|c|c|c|c|c|c|c|}
\hline Paper Application Rate & $\underline{\mathrm{Al}}$ & $\underline{\mathrm{B}}$ & $\underline{\mathrm{Cu}}$ & $\begin{array}{c}\text { Briley Site } \\
\text { Concentration }\end{array}$ & $\underline{\mathrm{Mn}}$ & $\underline{\text { Mo }}$ & $\underline{\mathrm{Na}}$ & $\underline{\mathrm{Zn}}$ \\
\hline & --.--.. & & & ----- & $\left.\mathrm{g}^{-1}\right)$ & -- & 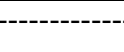 & 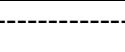 \\
\hline Standard Practice & 4709 a & $6.05 \mathrm{a}$ & $3.91 \mathrm{a}$ & $3664 \mathrm{a}$ & $119.8 \mathrm{a}$ & $0.45 \mathrm{ab}$ & $53.64 \mathrm{a}$ & $13.80 \mathrm{a}$ \\
\hline Control & $3822 \mathrm{a}$ & $6.48 \mathrm{a}$ & $2.10 \mathrm{a}$ & $2676 \mathrm{a}$ & $120.3 \mathrm{a}$ & $0.29 \mathrm{a}$ & $29.35 \mathrm{a}$ & $15.50 \mathrm{a}$ \\
\hline 8 tons acre ${ }^{-1}$ & 9128 a & $6.88 \mathrm{a}$ & $2.50 \mathrm{a}$ & 6573 a & $110.8 \mathrm{a}$ & $0.59 \mathrm{~b}$ & $37.67 \mathrm{a}$ & $19.08 \mathrm{a}$ \\
\hline 16 tons acre a $^{-1}$ & 3888 a & $7.60 \mathrm{a}$ & $2.01 \mathrm{a}$ & $3085 \mathrm{a}$ & $103.4 \mathrm{a}$ & $0.47 \mathrm{ab}$ & $33.51 \mathrm{a}$ & $13.22 \mathrm{a}$ \\
\hline 24 tons acre ${ }^{-1}$ & $7371 \mathrm{a}$ & $6.25 \mathrm{a}$ & $2.83 \mathrm{a}$ & $6079 \mathrm{a}$ & $92.2 \mathrm{a}$ & $0.47 \mathrm{ab}$ & $24.66 \mathrm{a}$ & $16.17 \mathrm{a}$ \\
\hline 32 tons acre ${ }^{-1}$ & \multicolumn{7}{|c|}{ Content } & $18.05 \mathrm{a}$ \\
\hline & --------- & ------ & ---- & --------- & $\left.\mathrm{g} \mathrm{m}^{-2}\right)-$ & $\begin{array}{l}----1 \\
--1\end{array}$ & ----------- & --------- \\
\hline Standard Practice & $12725 \mathrm{a}$ & $15.72 \mathrm{a}$ & $10.35 \mathrm{~b}$ & $10040 \mathrm{a}$ & $309.4 \mathrm{~b}$ & $1.19 \mathrm{a}$ & $121.94 \mathrm{a}$ & $35.55 \mathrm{a}$ \\
\hline Control & $10353 \mathrm{a}$ & $17.77 \mathrm{a}$ & $5.87 \mathrm{a}$ & $7224 \mathrm{a}$ & $325.1 \mathrm{~b}$ & $0.77 \mathrm{a}$ & $73.91 \mathrm{a}$ & $42.42 \mathrm{a}$ \\
\hline 8 tons acre ${ }^{-1}$ & $15702 \mathrm{a}$ & $12.68 \mathrm{a}$ & $5.11 \mathrm{ab}$ & $11479 \mathrm{a}$ & $264.3 \mathrm{ab}$ & $1.19 \mathrm{a}$ & $74.44 \mathrm{a}$ & $41.58 \mathrm{a}$ \\
\hline 16 tons acre ${ }^{-1}$ & 8266 a & $13.32 \mathrm{a}$ & $4.00 \mathrm{ab}$ & $6709 \mathrm{a}$ & $210.0 \mathrm{a}$ & $0.95 \mathrm{a}$ & $68.15 \mathrm{a}$ & $22.61 \mathrm{a}$ \\
\hline 24 tons acre ${ }^{-1}$ & $17805 \mathrm{a}$ & $14.59 \mathrm{a}$ & $6.68 \mathrm{ab}$ & $14690 \mathrm{a}$ & $222.0 \mathrm{ab}$ & $1.13 \mathrm{a}$ & $61.41 \mathrm{a}$ & $39.16 \mathrm{a}$ \\
\hline 32 tons acre ${ }^{-1}$ & $26337 \mathrm{a}$ & $19.64 \mathrm{a}$ & $7.68 \mathrm{ab}$ & $18034 \mathrm{a}$ & $219.3 \mathrm{ab}$ & $1.37 \mathrm{a}$ & $130.16 \mathrm{a}$ & $42.13 \mathrm{a}$ \\
\hline \multicolumn{9}{|c|}{ Eastwood Site } \\
\hline \multicolumn{9}{|c|}{ Concentration } \\
\hline & -------- & $\cdots$ & - = & 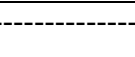 & $\left.\mathrm{g}^{-1}\right)$ & - n & 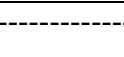 & -'---- \\
\hline Standard Practice & 5063 a & $5.78 \mathrm{ab}$ & $2.31 \mathrm{a}$ & $3185 \mathrm{a}$ & $48.0 \mathrm{a}$ & $0.47 \mathrm{a}$ & $51.61 \mathrm{a}$ & $7.30 \mathrm{ab}$ \\
\hline Control & $7848 \mathrm{~b}$ & $6.89 \mathrm{ab}$ & $2.19 \mathrm{a}$ & $4705 \mathrm{~b}$ & $60.8 \mathrm{a}$ & $0.54 \mathrm{a}$ & $61.34 \mathrm{a}$ & $10.47 \mathrm{bc}$ \\
\hline 4 tons acre ${ }^{-1}$ & $8472 \mathrm{~b}$ & $6.88 \mathrm{ab}$ & $2.54 \mathrm{a}$ & $4931 \mathrm{~b}$ & $41.3 \mathrm{a}$ & $0.57 \mathrm{a}$ & $64.82 \mathrm{a}$ & $10.93 \mathrm{bc}$ \\
\hline 8 tons acre ${ }^{-1}$ & $7331 \mathrm{ab}$ & $7.26 \mathrm{~b}$ & $2.19 \mathrm{a}$ & $4513 a b$ & $62.7 \mathrm{a}$ & $0.58 \mathrm{a}$ & $82.64 \mathrm{a}$ & $8.04 \mathrm{abc}$ \\
\hline 12 tons acre ${ }^{-1}$ & $9300 \mathrm{~b}$ & $7.52 \mathrm{~b}$ & $2.25 \mathrm{a}$ & $5300 \mathrm{~b}$ & $40.5 \mathrm{a}$ & $0.44 \mathrm{a}$ & $67.38 \mathrm{a}$ & $11.55 \mathrm{c}$ \\
\hline 16 tons acre ${ }^{-1}$ & \multicolumn{7}{|c|}{ Content } & $6.23 \mathrm{a}$ \\
\hline & ---------- & 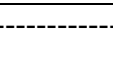 & - - & ---------- & $\left.\mathrm{g} \mathrm{m}^{-2}\right)$ & -------- & - & - \\
\hline Standard Practice & $10631 \mathrm{a}$ & $11.47 \mathrm{a}$ & $4.74 \mathrm{a}$ & $6622 \mathrm{a}$ & $98.6 \mathrm{a}$ & $0.928 \mathrm{a}$ & $103.6 \mathrm{a}$ & $15.55 \mathrm{a}$ \\
\hline Control & $18172 \mathrm{ab}$ & $15.90 \mathrm{a}$ & $5.00 \mathrm{a}$ & $10859 a b$ & $142.5 \mathrm{a}$ & $1.275 \mathrm{a}$ & $140.9 \mathrm{a}$ & $24.44 \mathrm{a}$ \\
\hline 4 tons acre ${ }^{-1}$ & $19643 \mathrm{ab}$ & $16.00 \mathrm{a}$ & $5.82 \mathrm{a}$ & $11499 b$ & $94.5 \mathrm{a}$ & $1.220 \mathrm{a}$ & $145.2 \mathrm{a}$ & $25.31 \mathrm{a}$ \\
\hline 8 tons acre ${ }^{-1}$ & $17357 \mathrm{ab}$ & $16.90 \mathrm{a}$ & $5.09 \mathrm{a}$ & $10715 \mathrm{ab}$ & $152.6 \mathrm{a}$ & $1.345 \mathrm{a}$ & $171.8 \mathrm{a}$ & $18.69 \mathrm{a}$ \\
\hline 12 tons acre ${ }^{-1}$ & 20999 b & $16.76 \mathrm{a}$ & $5.09 \mathrm{a}$ & $11872 b$ & $92.37 \mathrm{a}$ & $1.020 \mathrm{a}$ & $154.3 \mathrm{a}$ & $26.10 \mathrm{a}$ \\
\hline 16 tons acre ${ }^{-1}$ & $13495 \mathrm{ab}$ & $11.81 \mathrm{a}$ & $5.42 \mathrm{a}$ & $8406 \mathrm{ab}$ & $137.7 \mathrm{a}$ & $1.230 \mathrm{a}$ & $151.7 \mathrm{a}$ & $15.40 \mathrm{a}$ \\
\hline
\end{tabular}


Table 18. Soil concentration and content of metals at $0-20 \mathrm{~cm}$ depth in year $1 \uparrow$.

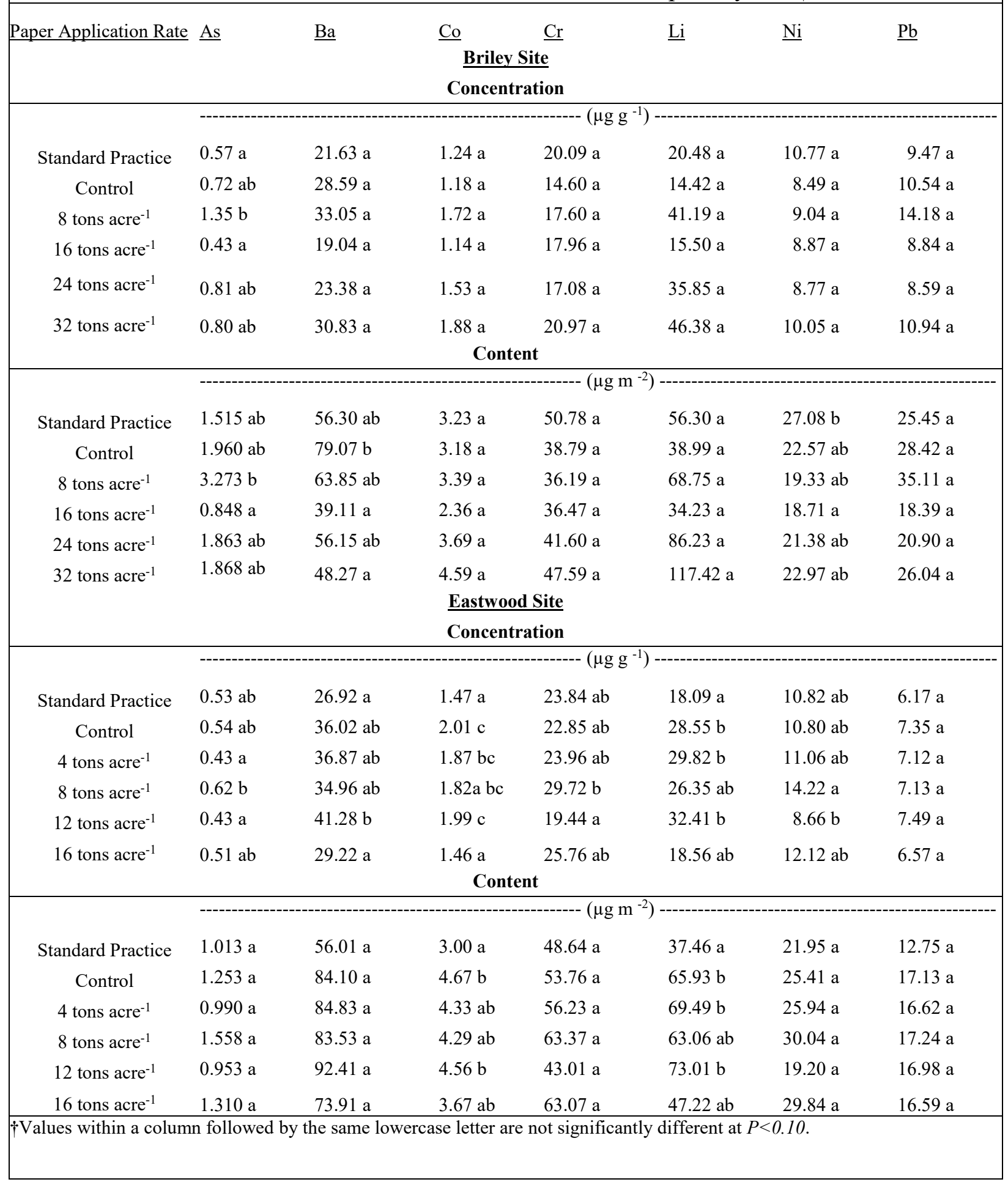


Table 19. Soil bulk density and concentration and content of $\mathrm{C}$ and plant macronutrients at $0-20$ $\mathrm{cm}$ depth in year $2 \uparrow$.

\begin{tabular}{|c|c|c|c|c|c|c|c|c|}
\hline$\frac{\text { Paper Application }}{\underline{\text { Rate }}}$ & $\begin{array}{l}\text { Bulk } \\
\underline{\text { Density }}\end{array}$ & $\underline{\mathrm{C}}$ & Co & $\frac{\frac{P}{\text { Site }}}{\text { tration }}$ & $\underline{\mathrm{K}}$ & $\underline{\mathrm{Ca}}$ & $\underline{\mathrm{Mg}}$ & $\underline{\mathrm{S}}$ \\
\hline & & \multicolumn{2}{|c|}{-------- $(\%)$--------- } & \multicolumn{4}{|c|}{ 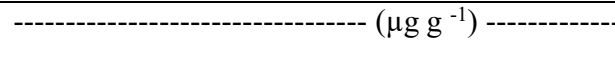 } & 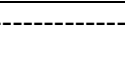 \\
\hline Standard Practice & $1.31 \mathrm{bc}$ & $1.32 \mathrm{ab}$ & $0.05 \mathrm{a}$ & $46.74 \mathrm{a}$ & $523.7 \mathrm{a}$ & $1036 \mathrm{a}$ & $729.5 \mathrm{a}$ & $70.38 \mathrm{ab}$ \\
\hline Control & $1.34 \mathrm{c}$ & $1.03 \mathrm{a}$ & $0.03 \mathrm{a}$ & $35.69 \mathrm{a}$ & $442.1 \mathrm{a}$ & $471 \mathrm{a}$ & $616.5 \mathrm{a}$ & $50.34 \mathrm{a}$ \\
\hline 8 tons acre ${ }^{-1}$ & $1.26 \mathrm{bc}$ & $1.28 \mathrm{ab}$ & $0.04 \mathrm{a}$ & $41.54 \mathrm{a}$ & $467.2 \mathrm{a}$ & $1114 \mathrm{a}$ & $681.4 \mathrm{a}$ & $64.38 \mathrm{ab}$ \\
\hline 16 tons acre ${ }^{-1}$ & $1.21 \mathrm{abc}$ & $1.78 \mathrm{ab}$ & $0.05 \mathrm{a}$ & $46.90 \mathrm{a}$ & $427.0 \mathrm{a}$ & $2534 \mathrm{ab}$ & $601.3 \mathrm{a}$ & $81.51 \mathrm{~b}$ \\
\hline 24 tons acre ${ }^{-1}$ & $1.19 \mathrm{ab}$ & $2.18 \mathrm{~b}$ & $0.05 \mathrm{a}$ & $47.53 \mathrm{a}$ & $489.8 \mathrm{a}$ & $4047 \mathrm{~b}$ & $631.0 \mathrm{a}$ & $82.60 \mathrm{~b}$ \\
\hline 32 tons acre ${ }^{-1}$ & $1.10 \mathrm{a}$ & $2.31 \mathrm{~b}$ & $0.04 \mathrm{a}$ & $\begin{array}{l}42.69 \mathrm{a} \\
\text { tent }\end{array}$ & $461.5 \mathrm{a}$ & $3649 \mathrm{~b}$ & $650.3 \mathrm{a}$ & $72.95 \mathrm{ab}$ \\
\hline & & \multicolumn{2}{|c|}{------- $\left(\mathrm{g} \mathrm{m}^{-2}\right)$------- } & \multicolumn{5}{|c|}{ 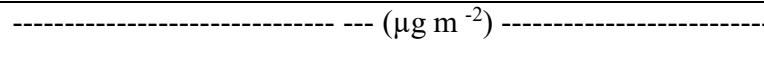 } \\
\hline Standard Practice & & $33.66 \mathrm{ab}$ & $1.218 \mathrm{a}$ & $120 \mathrm{a}$ & $1353 \mathrm{a}$ & $2668 \mathrm{a}$ & 1887 a & $179 \mathrm{a}$ \\
\hline Control & & $27.70 \mathrm{a}$ & $0.793 \mathrm{a}$ & $95 \mathrm{a}$ & $1252 \mathrm{a}$ & $1301 \mathrm{a}$ & $1761 \mathrm{a}$ & $134 \mathrm{a}$ \\
\hline 8 tons acre ${ }^{-1}$ & & $31.94 \mathrm{ab}$ & $1.043 \mathrm{a}$ & $104 \mathrm{a}$ & $1187 \mathrm{a}$ & $2701 \mathrm{a}$ & 1737 a & $159 \mathrm{a}$ \\
\hline 16 tons acre ${ }^{-1}$ & & $37.51 \mathrm{ab}$ & $1.085 \mathrm{a}$ & $108 \mathrm{a}$ & $1031 \mathrm{a}$ & $4992 \mathrm{ab}$ & $1455 \mathrm{a}$ & $183 \mathrm{a}$ \\
\hline 24 tons acre ${ }^{-1}$ & & $43.69 \mathrm{ab}$ & $1.125 \mathrm{a}$ & $107 \mathrm{a}$ & $1152 \mathrm{a}$ & $7513 b$ & $1503 \mathrm{a}$ & $178 \mathrm{a}$ \\
\hline 32 tons acre ${ }^{-1}$ & & $46.24 \mathrm{~b}$ & $\begin{array}{r}0.830 \mathrm{a} \\
\underline{\mathbf{E a}}\end{array}$ & $\begin{array}{l}92 \mathrm{a} \\
\text { od Site }\end{array}$ & $1015 \mathrm{a}$ & $6987 \mathrm{~b}$ & $1435 \mathrm{a}$ & $155 \mathrm{a}$ \\
\hline \multicolumn{9}{|c|}{ Concentration } \\
\hline & & \multicolumn{2}{|c|}{---------- $(\%)$---------- } & \multicolumn{4}{|c|}{ 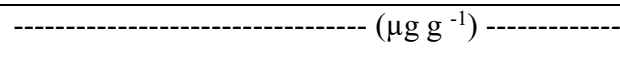 } & \\
\hline Standard Practice & $1.43 \mathrm{a}$ & $0.83 \mathrm{a}$ & $0.053 \mathrm{a}$ & $76.18 \mathrm{a}$ & $313.5 \mathrm{a}$ & $664 \mathrm{ab}$ & $269.5 \mathrm{a}$ & $60.94 \mathrm{a}$ \\
\hline Control & $1.37 \mathrm{ab}$ & $1.02 \mathrm{a}$ & $0.055 \mathrm{a}$ & $86.58 \mathrm{a}$ & $842.4 \mathrm{a}$ & $338 \mathrm{a}$ & $648.5 \mathrm{a}$ & $75.23 \mathrm{a}$ \\
\hline 4 tons acre ${ }^{-1}$ & $1.37 \mathrm{ab}$ & $0.99 \mathrm{a}$ & $0.055 \mathrm{a}$ & $84.30 \mathrm{a}$ & $857.9 \mathrm{a}$ & $559 \mathrm{ab}$ & $681.1 \mathrm{a}$ & $60.33 \mathrm{a}$ \\
\hline 8 tons acre ${ }^{-1}$ & $1.37 \mathrm{ab}$ & $1.03 \mathrm{a}$ & $0.058 \mathrm{a}$ & $84.07 \mathrm{a}$ & $330.0 \mathrm{a}$ & $1005 \mathrm{ab}$ & $251.4 \mathrm{a}$ & $74.61 \mathrm{a}$ \\
\hline 12 tons acre ${ }^{-1}$ & $1.27 \mathrm{a}$ & $0.90 \mathrm{a}$ & $0.058 \mathrm{a}$ & $78.94 \mathrm{a}$ & $281.9 \mathrm{a}$ & $1290 \mathrm{~b}$ & $233.0 \mathrm{a}$ & $75.46 \mathrm{a}$ \\
\hline 16 tons acre ${ }^{-1}$ & \multicolumn{7}{|c|}{ Content } & $62.28 \mathrm{a}$ \\
\hline & & \multicolumn{2}{|c|}{----- $\left(\mathrm{g} \mathrm{m}^{-2}\right)$-- } & \multicolumn{4}{|c|}{--------------------------------- $\left(\mu \mathrm{g} \mathrm{m}^{-2}\right)$} & 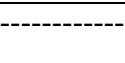 \\
\hline Standard Practice & & $23.60 \mathrm{a}$ & $1.478 \mathrm{a}$ & $217 \mathrm{a}$ & $883 \mathrm{a}$ & $1871 \mathrm{ab}$ & $758 \mathrm{a}$ & $173 \mathrm{a}$ \\
\hline Control & & $27.16 \mathrm{a}$ & $1.523 \mathrm{a}$ & $235 \mathrm{a}$ & $2346 \mathrm{a}$ & $907 \mathrm{a}$ & $1805 \mathrm{a}$ & $202 \mathrm{a}$ \\
\hline 4 tons acre ${ }^{-1}$ & & $24.49 \mathrm{a}$ & $1.428 \mathrm{a}$ & $233 \mathrm{a}$ & $2348 \mathrm{a}$ & $1488 \mathrm{~b}$ & $1865 \mathrm{a}$ & $163 \mathrm{a}$ \\
\hline 8 tons acre ${ }^{-1}$ & & $26.48 \mathrm{a}$ & $1.545 \mathrm{a}$ & $226 \mathrm{a}$ & $884 \mathrm{a}$ & $2678 \mathrm{ab}$ & $677 \mathrm{a}$ & $199 \mathrm{a}$ \\
\hline 12 tons acre ${ }^{-1}$ & & $24.34 \mathrm{a}$ & $1.335 \mathrm{a}$ & $190 \mathrm{a}$ & $682 \mathrm{a}$ & $3056 \mathrm{~b}$ & $561 \mathrm{a}$ & $177 \mathrm{a}$ \\
\hline 16 tons acre ${ }^{-1}$ & & $24.87 \mathrm{a}$ & $1.408 \mathrm{a}$ & $214 \mathrm{a}$ & $847 \mathrm{a}$ & $3203 \mathrm{~b}$ & $676 \mathrm{a}$ & $177 \mathrm{a}$ \\
\hline
\end{tabular}


Table 20. Soil concentration and content of plant micronutrients at $0-20 \mathrm{~cm}$ depth in year $2 \uparrow$.

\begin{tabular}{|c|c|c|c|c|c|c|c|c|}
\hline Paper Application Rate & $\underline{\mathrm{Al}}$ & $\underline{\mathrm{B}}$ & $\underline{\mathrm{Cu}}$ & $\frac{\frac{\mathrm{Fe}}{\text { ey Site }}}{\text { ntration }}$ & $\underline{\mathrm{Mn}}$ & $\underline{\text { Mo }}$ & $\underline{\mathrm{Na}}$ & $\underline{\mathrm{Zn}}$ \\
\hline & - & & & 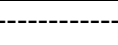 & $\left.\mathrm{g}^{-1}\right)-$ & & & \\
\hline Standard Practice & $9212 \mathrm{a}$ & $5.26 \mathrm{ab}$ & $3.34 \mathrm{ab}$ & $4794 \mathrm{a}$ & $51.07 \mathrm{a}$ & $1.22 \mathrm{ab}$ & $163.9 \mathrm{ab}$ & $9.56 \mathrm{a}$ \\
\hline Control & 8113 a & $6.49 \mathrm{ab}$ & $3.32 \mathrm{ab}$ & 4519 a & $48.98 \mathrm{a}$ & $1.15 \mathrm{ab}$ & $155.9 \mathrm{ab}$ & $7.68 \mathrm{a}$ \\
\hline 8 tons acre ${ }^{-1}$ & 8622 a & $4.51 \mathrm{a}$ & $3.13 \mathrm{ab}$ & 4564 a & $49.06 \mathrm{a}$ & $0.83 \mathrm{a}$ & $119.3 \mathrm{ab}$ & $9.19 \mathrm{a}$ \\
\hline 16 tons acre ${ }^{-1}$ & 8078 a & $6.69 \mathrm{ab}$ & $3.12 \mathrm{a}$ & $4175 \mathrm{a}$ & $57.31 \mathrm{a}$ & $1.02 \mathrm{ab}$ & $103.7 \mathrm{a}$ & $8.76 \mathrm{a}$ \\
\hline 24 tons acre ${ }^{-1}$ & 8464 a & $6.06 \mathrm{ab}$ & $5.30 \mathrm{~b}$ & $4772 \mathrm{a}$ & $59.69 \mathrm{a}$ & $1.93 \mathrm{~b}$ & $271.0 \mathrm{~b}$ & $9.76 \mathrm{a}$ \\
\hline 32 tons acre ${ }^{-1}$ & \multicolumn{7}{|c|}{ Content } & $8.73 \mathrm{a}$ \\
\hline & -------- & - & - & ------- & $\left.\mathrm{m}^{-2}\right)$ & 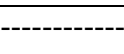 & -------- & 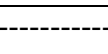 \\
\hline Standard Practice & $23908 \mathrm{a}$ & $14.01 \mathrm{a}$ & $8.50 \mathrm{a}$ & $12436 \mathrm{a}$ & $131.0 \mathrm{a}$ & $3.053 \mathrm{a}$ & $410.23 \mathrm{a}$ & $24.53 \mathrm{a}$ \\
\hline Control & $22959 \mathrm{a}$ & $17.24 \mathrm{a}$ & $8.95 \mathrm{a}$ & $12589 \mathrm{a}$ & $130.7 \mathrm{a}$ & $2.973 \mathrm{a}$ & $418.19 \mathrm{a}$ & $21.67 \mathrm{a}$ \\
\hline 8 tons acre ${ }^{-1}$ & $21930 \mathrm{a}$ & $11.42 \mathrm{a}$ & $7.90 \mathrm{a}$ & $11668 \mathrm{a}$ & $122.9 \mathrm{a}$ & $2.160 \mathrm{a}$ & $305.98 \mathrm{a}$ & $23.18 \mathrm{a}$ \\
\hline 16 tons acre $\mathrm{e}^{-1}$ & $19521 \mathrm{a}$ & $16.14 \mathrm{a}$ & $7.11 \mathrm{a}$ & $10004 \mathrm{a}$ & $127.6 \mathrm{a}$ & $2.140 \mathrm{a}$ & $239.23 \mathrm{a}$ & $20.09 \mathrm{a}$ \\
\hline 24 tons acre ${ }^{-1}$ & $20051 \mathrm{a}$ & $14.91 \mathrm{a}$ & $12.19 \mathrm{a}$ & $11275 \mathrm{a}$ & $142.0 \mathrm{a}$ & $4.410 \mathrm{a}$ & $644.68 \mathrm{a}$ & $22.61 \mathrm{a}$ \\
\hline 32 tons acre ${ }^{-1}$ & $18436 \mathrm{a}$ & $16.45 \mathrm{a}$ & $7.74 \mathrm{a}$ & 9701 a & $133.9 \mathrm{a}$ & $1.838 \mathrm{a}$ & $299.27 \mathrm{a}$ & $18.86 \mathrm{a}$ \\
\hline \multicolumn{9}{|c|}{ Eastwood Site } \\
\hline \multicolumn{9}{|c|}{ Concentration } \\
\hline & \multicolumn{8}{|c|}{ 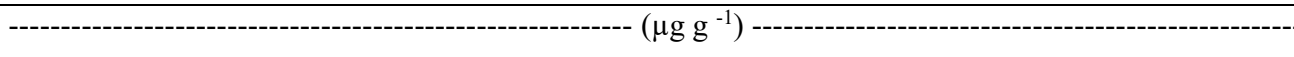 } \\
\hline Standard Practice & 5232 a & $6.79 \mathrm{ab}$ & $2.93 \mathrm{a}$ & 3912 a & $101.9 \mathrm{ab}$ & $0.82 \mathrm{ab}$ & $53.04 \mathrm{a}$ & $17.56 \mathrm{a}$ \\
\hline Control & $11698 \mathrm{a}$ & $9.34 \mathrm{~b}$ & $3.91 \mathrm{a}$ & $7118 \mathrm{a}$ & $121.8 \mathrm{ab}$ & $0.77 \mathrm{a}$ & $73.65 \mathrm{a}$ & $21.16 \mathrm{a}$ \\
\hline 4 tons acre ${ }^{-1}$ & 11664 a & $7.59 \mathrm{ab}$ & $3.91 \mathrm{a}$ & 7137 a & $99.3 \mathrm{a}$ & $0.62 \mathrm{a}$ & $64.42 \mathrm{a}$ & $15.90 \mathrm{a}$ \\
\hline 8 tons acre ${ }^{-1}$ & $5377 \mathrm{a}$ & $4.93 \mathrm{a}$ & $4.26 \mathrm{a}$ & 3968 a & $124.8 \mathrm{ab}$ & $1.09 \mathrm{~b}$ & $84.71 \mathrm{a}$ & $14.95 \mathrm{a}$ \\
\hline 12 tons acre ${ }^{-1}$ & 5436 a & $4.68 \mathrm{a}$ & $3.51 \mathrm{a}$ & 3595 a & $139.8 \mathrm{~b}$ & $0.81 \mathrm{ab}$ & $55.01 \mathrm{a}$ & $19.36 \mathrm{a}$ \\
\hline 16 tons acre ${ }^{-1}$ & $5140 \mathrm{a}$ & $4.31 \mathrm{a}$ & $3.00 \mathrm{a}$ & $3500 \mathrm{a}$ & $118.5 \mathrm{ab}$ & $0.79 \mathrm{ab}$ & $69.91 \mathrm{a}$ & $11.19 \mathrm{a}$ \\
\hline \multicolumn{9}{|c|}{ Content } \\
\hline & --------- & $-\cdots-\cdot$ & $-\cdots$ & - & $\left(\mathrm{m}^{-2}\right)--$ & - & --------- & ------- \\
\hline Standard Practice & $14765 \mathrm{a}$ & $19.33 \mathrm{ab}$ & $8.34 \mathrm{a}$ & $11012 \mathrm{a}$ & $290.8 \mathrm{ab}$ & $2.323 \mathrm{a}$ & $150.85 \mathrm{a}$ & $50.02 \mathrm{a}$ \\
\hline Control & $32450 \mathrm{a}$ & $25.16 \mathrm{~b}$ & $10.70 \mathrm{a}$ & $19693 \mathrm{a}$ & $329.7 \mathrm{ab}$ & $1.773 \mathrm{a}$ & $198.49 \mathrm{a}$ & $57.02 \mathrm{a}$ \\
\hline 4 tons acre ${ }^{-1}$ & $31731 \mathrm{a}$ & $20.51 \mathrm{ab}$ & $10.71 \mathrm{a}$ & $17610 \mathrm{a}$ & $237.9 \mathrm{a}$ & $76.910 \mathrm{a}$ & $134.91 \mathrm{a}$ & $72.88 \mathrm{a}$ \\
\hline 8 tons acre ${ }^{-1}$ & $14457 \mathrm{a}$ & $12.92 \mathrm{a}$ & $10.93 \mathrm{a}$ & $10659 \mathrm{a}$ & $339.9 \mathrm{ab}$ & $2.768 \mathrm{a}$ & 209.94 a & $40.62 \mathrm{a}$ \\
\hline 12 tons acre ${ }^{-1}$ & 12967 a & $11.99 \mathrm{a}$ & $8.60 \mathrm{a}$ & 8527 a & $348.8 \mathrm{~b}$ & $1.960 \mathrm{a}$ & $136.59 \mathrm{a}$ & $44.46 \mathrm{a}$ \\
\hline 16 tons acre e $^{-1}$ & $14758 \mathrm{a}$ & $12.17 \mathrm{a}$ & $8.50 \mathrm{a}$ & $10460 \mathrm{a}$ & $326.4 \mathrm{ab}$ & $2.113 \mathrm{a}$ & $183.18 \mathrm{a}$ & $33.73 \mathrm{a}$ \\
\hline
\end{tabular}


Table 21. Soil concentration and content of metals at $0-20 \mathrm{~cm}$ depth in year $2 \uparrow$.

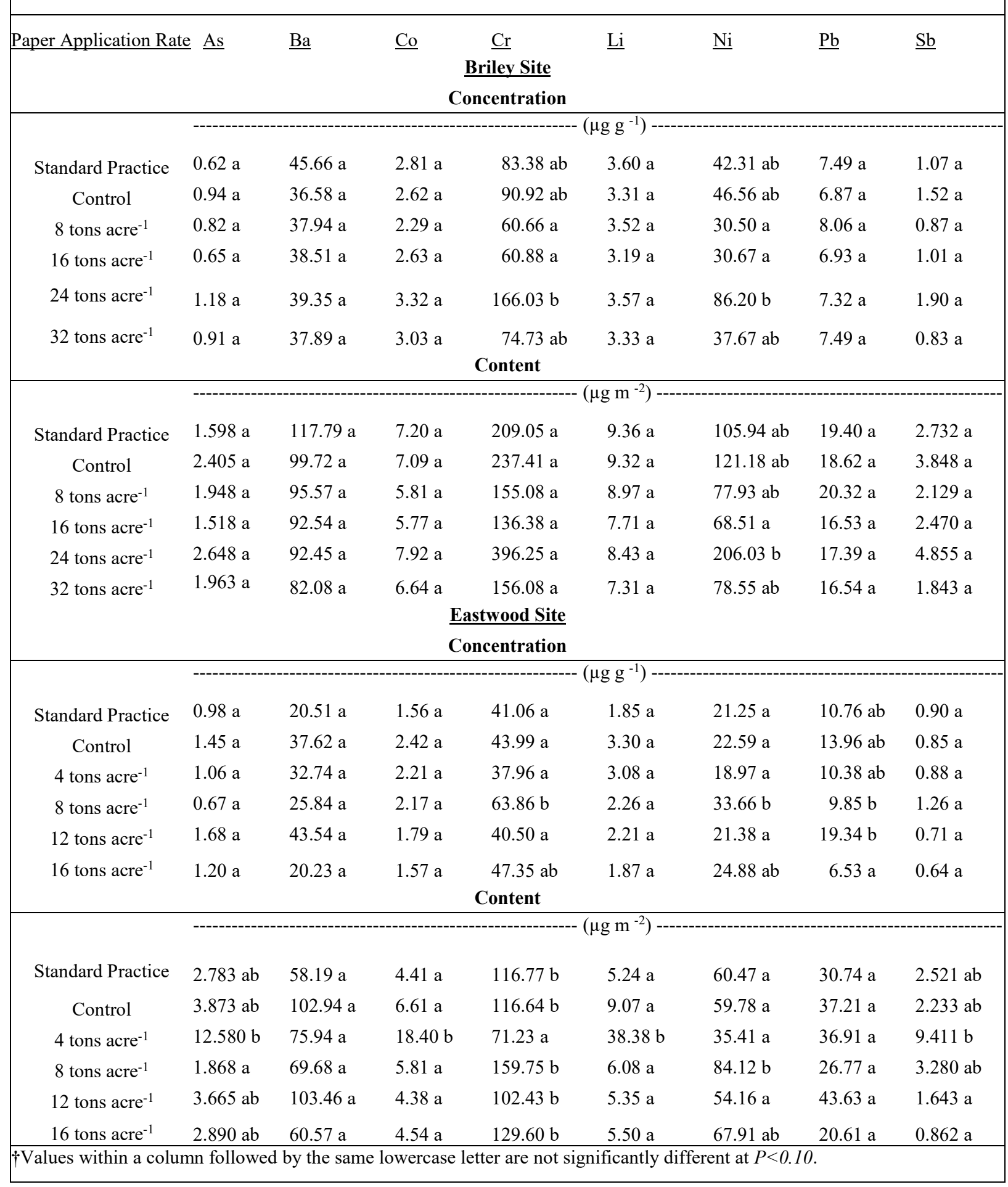


Table 22. Soil $\mathrm{pH}$ and concentration of extractable plant macronutrients at $0-20 \mathrm{~cm}$ depth in both years $\uparrow$.

\begin{tabular}{|c|c|c|c|c|c|c|}
\hline \multicolumn{7}{|c|}{$\frac{\text { Briley Site }}{2016}$} \\
\hline Standard Practice & $7.25 \mathrm{~b}$ & $17.75 \mathrm{a}$ & $82.50 \mathrm{a}$ & $7.25 \mathrm{ab}$ & $2443 \mathrm{c}$ & $7.55 \mathrm{a}$ \\
\hline Control & $6.65 \mathrm{ab}$ & $16.00 \mathrm{a}$ & $71.75 \mathrm{a}$ & $6.50 \mathrm{ab}$ & $1079 \mathrm{a}$ & $4.03 \mathrm{a}$ \\
\hline 8 tons acre $e^{-1}$ & $6.85 \mathrm{ab}$ & $12.75 \mathrm{a}$ & $87.25 \mathrm{a}$ & $6.75 \mathrm{ab}$ & $2045 \mathrm{bc}$ & $6.74 \mathrm{a}$ \\
\hline 16 tons acre ${ }^{-1}$ & $7.08 \mathrm{~b}$ & $16.75 \mathrm{a}$ & $84.75 \mathrm{a}$ & $7.00 \mathrm{~b}$ & $1446 \mathrm{abc}$ & $4.75 \mathrm{a}$ \\
\hline 24 tons acre ${ }^{-1}$ & $6.60 \mathrm{ab}$ & $10.75 \mathrm{a}$ & $87.25 \mathrm{a}$ & $6.75 \mathrm{ab}$ & $1217 \mathrm{a}$ & $4.68 \mathrm{a}$ \\
\hline 32 tons acre ${ }^{-1}$ & $5.85 \mathrm{a}$ & $12.50 \mathrm{a}$ & $\begin{array}{r}110.00 \mathrm{a} \\
\mathbf{2 0 1 7}\end{array}$ & $5.75 \mathrm{a}$ & $653 \mathrm{a}$ & $4.46 \mathrm{a}$ \\
\hline Standard Practice & $6.15 \mathrm{a}$ & $10.00 \mathrm{ab}$ & $88.00 \mathrm{a}$ & $6.25 \mathrm{~b}$ & $1710 \mathrm{a}$ & $7.80 \mathrm{a}$ \\
\hline Control & $5.70 \mathrm{a}$ & $9.50 \mathrm{a}$ & $71.75 \mathrm{a}$ & $5.50 \mathrm{a}$ & $699 \mathrm{a}$ & $5.28 \mathrm{a}$ \\
\hline 8 tons acre ${ }^{-1}$ & $6.20 \mathrm{ab}$ & $8.75 \mathrm{a}$ & $75.25 \mathrm{a}$ & $6.25 \mathrm{~b}$ & $1853 \mathrm{a}$ & $7.99 \mathrm{a}$ \\
\hline 16 tons acre ${ }^{-1}$ & $6.70 \mathrm{bc}$ & $15.25 \mathrm{~b}$ & $78.75 \mathrm{a}$ & $6.75 \mathrm{bc}$ & $3515 \mathrm{~b}$ & $11.52 \mathrm{~b}$ \\
\hline 24 tons acre ${ }^{-1}$ & $6.73 \mathrm{bc}$ & $13.00 \mathrm{ab}$ & $76.25 \mathrm{a}$ & $7.00 \mathrm{c}$ & $4299 \mathrm{~b}$ & $13.26 \mathrm{~b}$ \\
\hline 32 tons acre ${ }^{-1}$ & $7.08 \mathrm{c}$ & $20.75 \mathrm{c}$ & $93.50 \mathrm{a}$ & $7.00 \mathrm{c}$ & $6116 \mathrm{c}$ & $13.26 \mathrm{c}$ \\
\hline \multicolumn{7}{|c|}{$\underline{\text { Eastwood Site }}$} \\
\hline \multicolumn{7}{|c|}{2016} \\
\hline Standard Practice & $6.75 \mathrm{~b}$ & $5.75 \mathrm{a}$ & $45.00 \mathrm{a}$ & $6.50 \mathrm{a}$ & $2890 \mathrm{a}$ & $9.20 \mathrm{a}$ \\
\hline Control & $6.33 \mathrm{ab}$ & $6.75 \mathrm{a}$ & $77.00 \mathrm{~b}$ & $6.25 \mathrm{a}$ & $1947 \mathrm{a}$ & $7.75 \mathrm{a}$ \\
\hline 4 tons acre ${ }^{-1}$ & $6.48 \mathrm{ab}$ & $5.75 \mathrm{a}$ & $75.50 \mathrm{ab}$ & $6.25 \mathrm{a}$ & $2203 \mathrm{a}$ & $8.15 \mathrm{a}$ \\
\hline 8 tons acre ${ }^{-1}$ & $6.65 a b$ & $6.25 \mathrm{a}$ & $72.25 \mathrm{ab}$ & $6.75 \mathrm{a}$ & $2050 \mathrm{a}$ & $7.78 \mathrm{a}$ \\
\hline 12 tons acre ${ }^{-1}$ & $5.83 \mathrm{a}$ & $5.00 \mathrm{a}$ & $80.00 \mathrm{~b}$ & $5.75 \mathrm{a}$ & $1871 \mathrm{a}$ & $7.90 \mathrm{a}$ \\
\hline \multicolumn{7}{|c|}{2017} \\
\hline Standard Practice & $6.68 \mathrm{bc}$ & $15.00 \mathrm{a}$ & $91.50 \mathrm{a}$ & $7.00 \mathrm{~b}$ & $1295 \mathrm{ab}$ & $5.24 \mathrm{a}$ \\
\hline Control & $5.53 \mathrm{a}$ & $12.50 \mathrm{a}$ & $121.00 \mathrm{a}$ & $5.75 \mathrm{a}$ & $442 \mathrm{a}$ & $5.28 \mathrm{a}$ \\
\hline 4 tons acre ${ }^{-1}$ & $6.23 \mathrm{ab}$ & $15.75 \mathrm{a}$ & $127.75 \mathrm{a}$ & $6.50 \mathrm{a}$ & $1018 \mathrm{ab}$ & $5.96 \mathrm{a}$ \\
\hline 8 tons acre ${ }^{-1}$ & $7.38 \mathrm{c}$ & $14.75 \mathrm{a}$ & $90.75 \mathrm{a}$ & $7.50 \mathrm{~b}$ & $1551 \mathrm{bc}$ & $5.47 \mathrm{a}$ \\
\hline 12 tons acre $^{-1}$ & $7.23 \mathrm{c}$ & $14.50 \mathrm{a}$ & $71.50 \mathrm{a}$ & $7.25 \mathrm{~b}$ & $2090 \mathrm{c}$ & $7.21 \mathrm{a}$ \\
\hline 16 tons acre ${ }^{-1}$ & $6.78 \mathrm{bc}$ & $12.00 \mathrm{a}$ & $80.75 \mathrm{a}$ & $6.75 \mathrm{~b}$ & $1348 \mathrm{abc}$ & $5.29 \mathrm{a}$ \\
\hline
\end{tabular}




\subsection{PERFORMANCE ASSESSMENT}

\section{Improved native plant cover}

To calculate correlations, the standard practice treatment was removed so that treatment application rates could be analyzed as continuous variables. A positive correlation was observed between paper application rate and native plant cover over both growing seasons (Pearson correlation coefficient $=0.28, \mathrm{p}=0.01$ ). A negative correlation was also observed between paper application rate and invasive plant cover over both growing seasons (Pearson correlation coefficient $=-0.40, \mathrm{p}<0.001)$.

At the Briley site, native plant cover at the 32 tons acre ${ }^{-1}$ paper application rate was $42 \%$ higher than the control treatment, and $17 \%$ higher than the standard practice treatment. At the Eastwood site, native plant cover at the 16 tons acre ${ }^{-1}$ paper application rate was $48 \%$ higher than the control treatment, and $62 \%$ higher than the standard practice treatment. Although our target of a $50 \%$ increase in native plant cover in the highest paper application rates relative to controls was not achieved (45\% average across sites), our results were very close to the target. With respect to a target of a $50 \%$ increase in native plant cover in the highest paper application rates relative to the standard practice treatment, we exceeded our target in one plot (62\% at Eastwood) but fell short at Briley (17\%), achieving a $40 \%$ average across sites.

\section{Improved native plant biomass}

No positive correlation between planted grass biomass and paper application rate was observed. However, the Eastwood site alone exhibited a positive correlation (Pearson correlation coefficient $=0.42, \mathrm{p}<0.001)$. A negative correlation was observed between paper application rate and invasive plant biomass (Pearson correlation coefficient $=-0.19, \mathrm{p}=0.002$ ).

At the Briley site, native plant biomass at the 32 tons acre ${ }^{-1}$ paper application rate was $71 \%$ lower than the control treatment, and 355\% lower than the standard practice treatment. At the Eastwood site, native plant biomass at the 16 tons acre ${ }^{-1}$ paper application rate was $90 \%$ higher than the control treatment, and 96\% higher than the standard practice treatment. Although our target of a 50\% increase in native plant biomass in the highest paper application rates relative to controls was not achieved (10\% average across sites), we exceeded our target at one site (90\% at Eastwood). Because of the difficulties in incorporating the high application rates into the soil, when using 16 tons acre ${ }^{-1}$ across both sites, an average of $74 \%$ is achieved, which exceeds our target. With respect to the comparison between the highest rate and the standard practice treatment, when using 16 tons acre ${ }^{-1}$ across both sites, the average increase is $41 \%$, which is very close to our target. This failure to meet our objective with respect to biomass appears to have occurred due to a severe nutrient limitation at the Briley site. The paper was too effective at immobilizing the few nutrients in the soil, and the seeded native grasses in the standard practice treatment actually benefitted from the addition of nitrogen, which is highly uncommon. 


\section{Improved plant nutrition}

Based on preliminary soil testing and analyses of plant and soil samples throughout the demonstration, $\mathrm{P}, \mathrm{Ca}$, and $\mathrm{S}$ were determined to be deficient at both sites, while $\mathrm{N}, \mathrm{K}$, and Mo were deficient at the Briley site. Pearson correlation coefficients and probability levels are presented in Table 23. Plant concentrations of $\mathrm{Ca}$ and Mo were moderately correlated with paper application rate while $\mathrm{P}$ and $\mathrm{S}$ were weakly correlated at both sites. Because $\mathrm{N}$ and $\mathrm{K}$ concentrations in the paper were so low relative to soil concentrations, and because application rate had no effect on soil or plant concentrations of either element, correlations were not calculated for them. Regardless, we achieved our target of positive correlation between application rate and a deficient plant nutrient concentration for both $\mathrm{Ca}$ and Mo across both sites.

\begin{tabular}{|c|c|c|c|c|}
\hline & Briley Site & & Eastwood & \\
\hline Deficient & Pearson Correlation & & Pearson Correlation & \\
\hline Nutrient & Coefficient & p-level & Coefficient & p-level \\
\hline $\mathrm{P}$ & 0.44 & 0.057 & 0.44 & 0.054 \\
\hline $\mathrm{Ca}$ & 0.57 & 0.01 & 0.73 & $<0.001$ \\
\hline $\mathrm{S}$ & 0.44 & 0.058 & 0.41 & 0.07 \\
\hline Mo & 0.51 & 0.025 & 0.67 & 0.001 \\
\hline
\end{tabular}

\section{Improved soil chemical properties}

For this metric, correlations between soil concentrations of the deficient nutrients from the above metric and paper application rate were conducted. Of the deficient nutrients, only $\mathrm{Ca}$ concentration was correlated with paper application rate. As Ca content in the paper was high while being deficient in the soil, this is understandable. The correlation between plant concentrations in the other deficient nutrients and paper application rate is likely explained by changes in $\mathrm{pH}$ and other soil factors that influence nutrient availability, plant growth, and subsequent nutrient demand.

\begin{tabular}{|c|c|c|c|c|}
\hline \multirow[b]{2}{*}{$\frac{\text { Deficient }}{\text { Nutrient }}$} & \multicolumn{2}{|l|}{ Briley Site } & \multicolumn{2}{|c|}{ Eastwood Site } \\
\hline & $\frac{\text { Pearson Correlation }}{\text { Coefficient }}$ & p-level & $\frac{\text { Pearson Correlation }}{\text { Coefficient }}$ & p-level \\
\hline $\mathrm{P}$ & 0.29 & 0.21 & -0.15 & 0.52 \\
\hline $\mathrm{Ca}$ & 0.59 & 0.006 & 0.56 & 0.01 \\
\hline $\mathrm{S}$ & 0.41 & 0.07 & -0.01 & 0.95 \\
\hline Mo & 0.09 & 0.72 & 0.09 & 0.70 \\
\hline
\end{tabular}


In this metric, soil C:N ratios were also measured. Soil C:N ratios did not change as expected. Our target was a ratio greater than 30 in the first year as soil $\mathrm{N}$ is immobilized, and a ratio less than 30 thereafter as soil $\mathrm{N}$ becomes more available as the paper decomposed. In the Eastwood soil, C:N ratios were little changed year over year, were virtually identical between treatments, and remained below 30 throughout the demonstration (Figure 39). This was likely a result of higher soil $\mathrm{N}$ at this site and lower application rates due to the difficulties in incorporation of the higher rates.

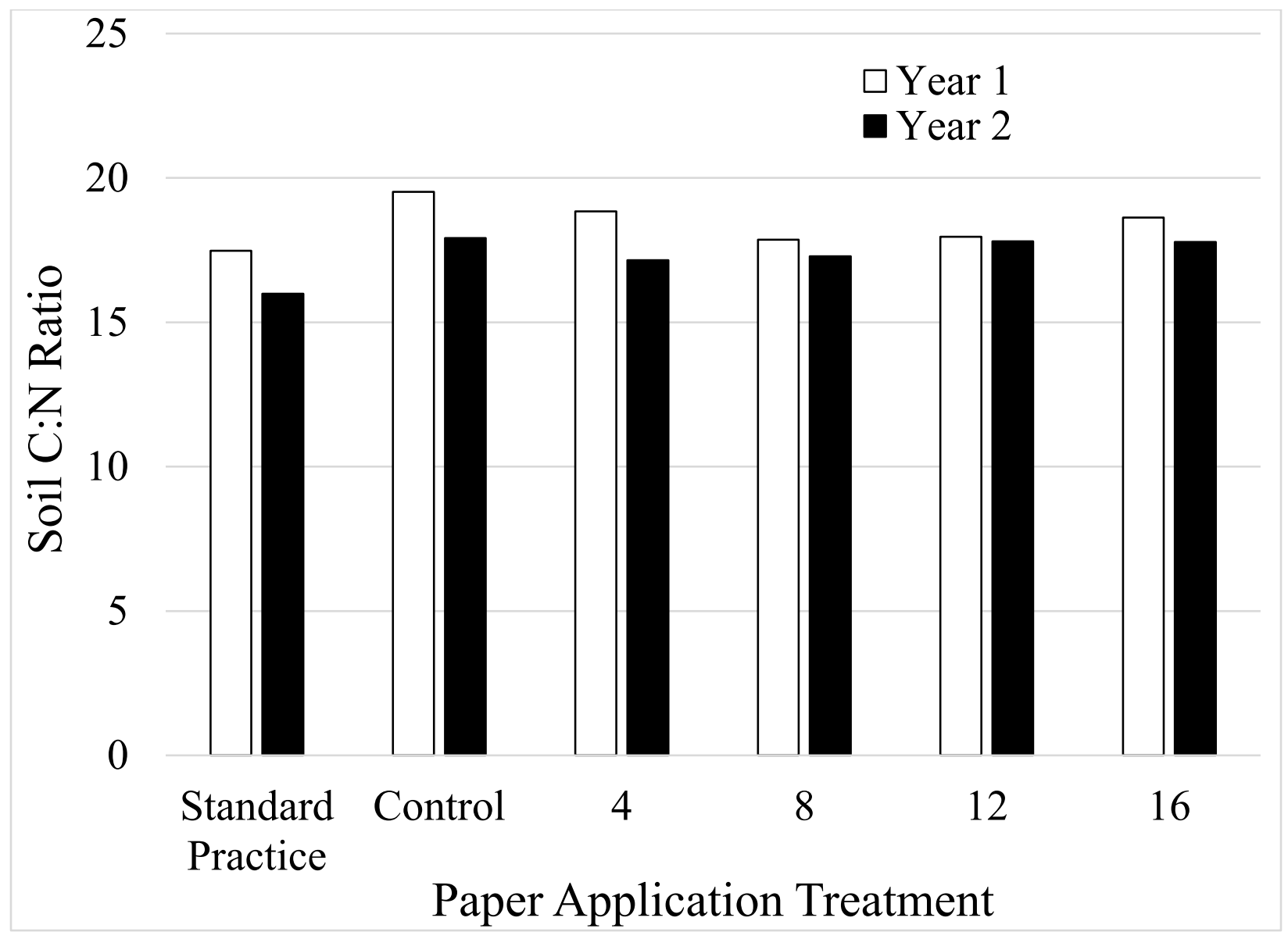

Figure 39. Soil C:N ratios at the Eastwood site. Mean ratios are across paper application treatments in both years.

At the Briley site, the opposite effect of what was anticipated was observed. Soil C:N ratios in year 1 were all below 30 , while all were above 30 in year 2 . This is likely due to the combination of very low $\mathrm{N}$ concentration in the soil and the concentration of paper material on the surface in the higher application rates. In year 1 , there was very little plant biomass to accumulate available $\mathrm{N}$, so it remained in the soil and resulted in a higher ratio. In year 2, biomass increased significantly (Figure 40) and accumulated much more of the available $\mathrm{N}$ in shoots. This was further confirmed by the inverse relationship between biomass and $\mathrm{N}$ content at this site in both years (Table 14) and confirms a $\mathrm{N}$ deficiency. Also in the second year, the surface paper likely had a greater influence on soil chemistry as it was mixed with the soil due to biological activity 
and began decomposing at a higher rate. This is shown in Figure 40, where $C: N$ ratios in the highest paper application treatments had lower soil $\mathrm{C}: \mathrm{N}$ ratios in year 1 , but much higher $\mathrm{C}: \mathrm{N}$ ratios in year 2 . This scenario likely means that the influence of the higher paper application rates on soil nutrients lasts longer than the 2 growing seasons that were monitored for the demonstration.

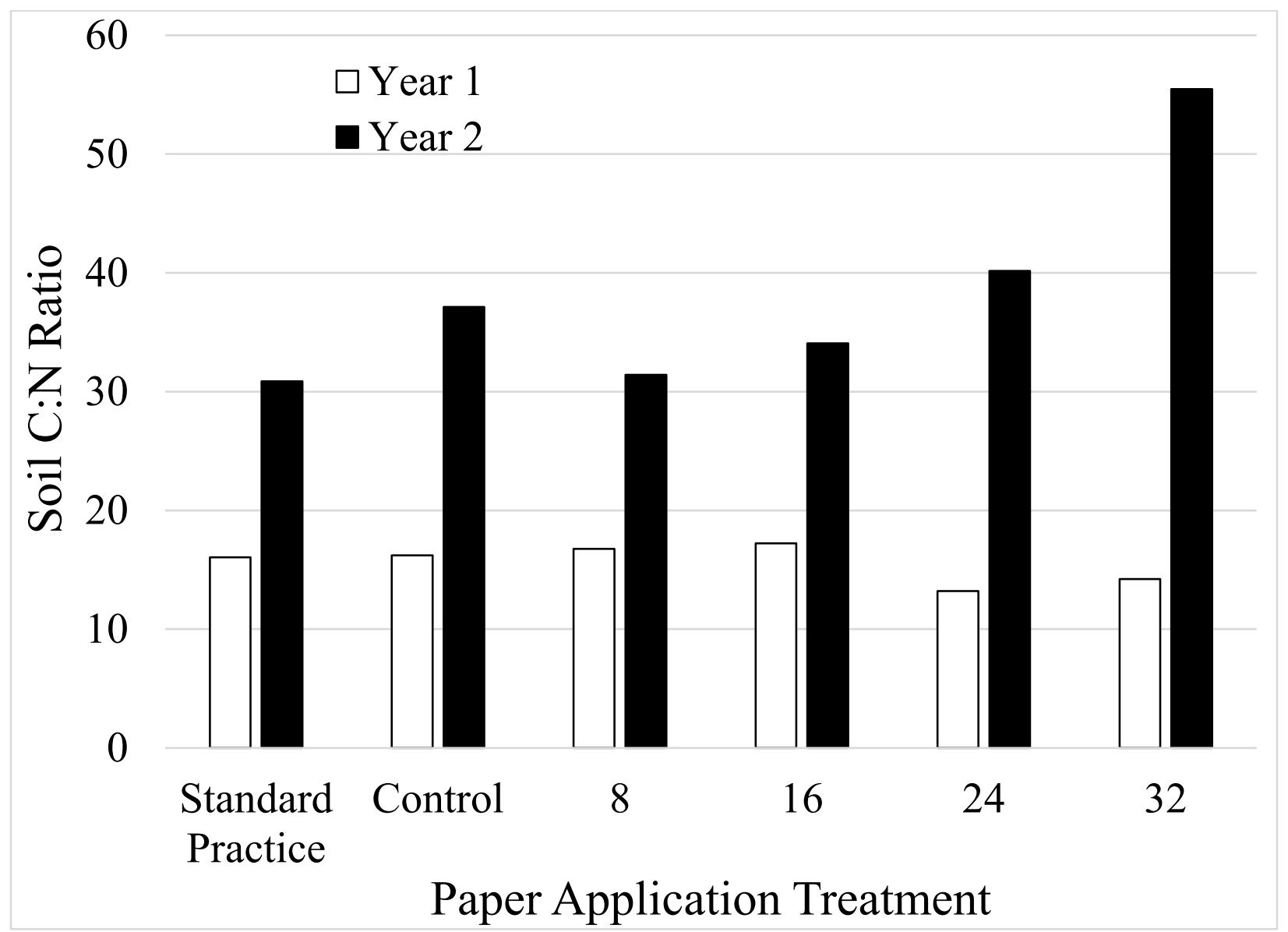

Figure 40. Soil $\mathrm{C}: \mathrm{N}$ ratios at the Briley site. Mean ratios are across paper application treatments in both years.

\section{Improve soil physical properties}

In this metric, soil $\mathrm{pH}$ and bulk density values were correlated with paper application rate, with the expectation that soil $\mathrm{pH}$ would increase with increasing paper application rate while soil bulk density would decrease. Both metrics were met, with the exception of bulk density at the Eastwood site. Soil $\mathrm{pH}$ was positively correlated with paper application rate at both the Briley (Pearson correlation coefficient $=0.73, \mathrm{p}<0.001)$ and Eastwood (Pearson correlation coefficient $=0.55, \mathrm{p}=0.01)$ sites. For bulk density, paper application rate was moderately negatively correlated with bulk density (Pearson correlation coefficient $=-0.60, p=0.005$ ), while no correlation was observed at the Eastwood site (Pearson correlation coefficient $=-0.07, \mathrm{p}=0.78$ ). This was likely a result of utilizing paper application rates at this site that were half of what was planned due to incorporation difficulties at higher rates. 


\section{Low contaminant loading}

In this metric, contaminant concentrations for EPA-regulated heavy metals were analyzed, with the expectation that no contaminant would be increased by more than $50 \%$ at the highest application rate. No contaminant reached a level even close to that number (Table 25). In fact, no significant increase was observed for any regulated metal in the highest application rates versus control treatments and no discernable increases could be attributed to paper application rates at any level for any regulated heavy metal. Increases that are presented in Table 25 are most likely the result of variation in the soil across the demonstration sites. Values presented as zeroes actually indicated decreases in that metal and, if presented, would indicate reductions in more regulated contaminants than increases.

\begin{tabular}{|c|c|c|c|c|c|c|c|}
\hline & $\underline{\mathrm{As}}$ & $\underline{\mathrm{Cr}}$ & $\underline{\mathrm{Cu}}$ & $\underline{\mathrm{Pb}}$ & $\underline{\text { Mo }}$ & $\underline{\mathrm{Ni}}$ & $\underline{\mathrm{Zn}}$ \\
\hline \multicolumn{8}{|c|}{ Briley Site } \\
\hline Concentration Increase (ppm) & $0^{\mathrm{a}}$ & 0 & 0.34 & 0.62 & 0 & 0 & 1.05 \\
\hline Percent Increase & 0 & 0 & 10.2 & 9.0 & 0 & 0 & 13.7 \\
\hline \multicolumn{8}{|c|}{ Eastwood Site } \\
\hline Concentration Increase (ppm) & 0 & 3.36 & 0 & 0 & 0.02 & 2.29 & 0 \\
\hline Percent Increase & 0 & 7.6 & 0 & 0 & 1.5 & 10.1 & 0 \\
\hline
\end{tabular}

Because most EPA-regulated heavy metals were not detected in analyzed paper samples, a very conservative calculation of application limits is presented here based on detection limits. Using detection limits, the limiting contaminant would be molybdenum. This is based solely on its concentration limitation by the EPA in relation to the detection limits of the analytical instrument used to quantify concentrations, and in no way reflects its concentration in the paper. But using this estimate, and assuming an annual application of the recommended 16 tons of pulverized paper over the same acre of land every year, the cumulative EPA loading limit would be reached in 231 years.

However, if using heavy metals that were actually detected in the paper, copper and zinc (both of which are plant micronutrients), then zinc is the limiting factor. At an annual paper application rate of 16 tons, the cumulative EPA loading limit would be reached in 3,900 years. 


\subsection{COST ASSESSMENT}

\subsection{COST MODEL}

Table 26. Cost model for pulverized paper demonstration.

Cost Element

Paper Disposal

Site Preparation

Environmental Benefits
Data Tracked During the Demonstration

Storage, Pickup, Transport, and Delivery of Paper

Equipment and Manpower Utilization, Soil Inputs

Soil and Vegetation Responses to Treatments
Estimated Costs

$\$ 6.00$ per ton

$\$ 100$ per acre

$\$-1000$ per acre

Paper Disposal: Fort Polk paper disposal costs for landfill placement run at $\$ 175$ per ton, including a tipping fee of $\$ 98$ per ton and an administration fee of $\$ 77$ per ton. Collection and storage of the paper from small batch sources did not incur an additional cost as it was included in a contract for collection of all recyclable materials from the same collection locations. Storage of the larger batches of paper required rental of a rolloff container. The 20 cubic yard rolloff cost $\$ 114$ per month, with a one-time charge of $\$ 250$ for dropoff and pickup. This rental was required due to our bagging and weighing for exact application rates and would not be necessary for full implementation. Thus, this cost was not included in the final cost calculations. However, if storage in a rolloff(s) container is deemed desirable, purchasing or acquiring an excess container would be cost effective. Because storage occurred in unused buildings, the storage cost for paper was $\$ 0$. Outside storage could be an option if blowing paper deposition in the area immediately surrounding the storage location is acceptable. Wetting the paper a single time causes the paper particles to stick together, which significantly reduces wind movement. Storage of paper in this way in an empty lot with a water hydrant would likely be most cost effective and easiest to store and load bulk paper material. Transport of bulk materials costs $\$ 0.40$ per ton per mile at Fort Polk. Our overall cost estimate used this number and an average distance of 15 miles for collection and disposal at a training land, giving an overall paper disposal cost of $\$ 6.00$ per ton.

Site Preparation: Because site preparation with a disk is not performed at every location, this additional cost of site preparation was included, although at other locations this will likely not be the case. Because most installation land management departments already own a disk, acquisition costs are not included. Tractor operation costs for disking average close to $\$ 8$ per acre nationwide, with an additional \$21 labor cost per acre for disking (\$42 per hour labor at a disking rate of 2 acres per hour). No other site preparation costs are required to incorporate pulverized paper into disturbed training lands undergoing rehabilitation.

Environmental Benefits: At the recommended 16 tons per acre rate (and a cost of $\$ 96$ for incorporation on 1 acre of land), the benefits will include an average reduction in bulk density of $5 \%$, a $20 \%$ increase in $\mathrm{pH}$ ( 1 unit), a 40\% increase in soil carbon, a 10\% increase in basal cover of planted grasses, a $25 \%$ decrease in weed basal cover, and more than double the biomass of native warm season grasses.

Current estimates indicate that costs associated with Army land rehabilitation are $\$ 2,000$ per acre $\left(\$ 4940 \mathrm{ha}^{-1}\right)$ and $50 \%$ of all rehabilitation activities on these lands fail. This assessment is supported by the literature, where published analyses indicate that only $52 \%$ of restoration goals 
are achieved (Lockwood and Pimm, 1999). An additional analysis of 82 published reports and a global survey indicates that for year-old restorations in unprotected sites the success rate is $50 \%$, but drops to $25 \%$ after 3 years (Godefroid et al., 2011). Assuming that half of all land rehabilitation actions currently must be repeated after 1 year and $3 / 4$ must be repeated after 3 years, a 3 year life cycle cost for current practices is twice the estimated per unit cost. This number is based on half of the original sites requiring additional rehabilitation in year 2 , while a quarter of the original sites requiring additional rehabilitation in year 3 along with half of the rerehabilitated sites from year 2 . Assuming $50 \%$ of failures are overcome with the addition of paper, the cost savings on a per acre basis amount to $\$ 2000$ per acre.

\subsection{COST DRIVERS}

The most important consideration for cost is paper movement. This single consideration will ultimately determine the cost effectiveness of technology implementation. Collection of paper from multiple sources and variable production rates will differ significantly both within and between installations. Smaller batches require greater collection times, removal from plastic bags, and disposal of plastic bags. Bulk materials can be collected and dumped easily from bulk containers, but requires larger equipment. Storage in an area that can be accessed by loaders and dump trucks will make paper utilization much more cost effective.

\subsection{COST ANALYSIS AND COMPARISON}

Current costs for disposal are $\$ 175$ per ton. Current land rehabilitation costs are $\$ 4000$ per acre when factoring in repeated efforts due to failure. Paper transportation costs $\$ 0.40$ per ton per mile using a tandem axle dump truck with 10 to 14 cubic yard capacity. Site preparation costs $\$ 8$ to disk paper in and $\$ 21$ in labor to operate, with an overall cost of $\$ 29$. Assuming an average distance from the paper source to the incorporation site of 15 miles, and utilizing a rate of 16 tons of paper per acre, the average acre will cost $\$ 96$ to transport paper and $\$ 29$ to incorporate it, for a grand total of $\$ 125$ per acre, or approximately $\$ 8$ per ton. This alone saves approximately $\$ 167$ per ton compared to landfill disposal. Assuming the addition of paper reduces rehabilitation failures by $50 \%$, this results in a cost savings of $\$ 2000$ per acre, or $\$ 125$ per ton of paper.

Overall, the cost savings realized from diversion of pulverized paper waste from landfills to degraded training lands is $\$ 4,672$ per acre, or $\$ 292$ per ton of paper diverted. As the average installation likely disposes of pulverized paper at a rate of 70 tons per year (based on populations of installations relative to Fort Polk and an assumption of similar per capita paper production rates), this could result in cost savings of $\$ 20,000$ per installation per year, and a diversion of 70 tons of paper from the waste stream. At the Service level, a cost savings greater than $\$ 1$ million per year could be realized. 


\subsection{IMPLEMENTATION ISSUES}

Demonstration and evaluation of pulverized paper utilization as a soil $\mathrm{C}$ source required approval from the Louisiana Department of Agriculture and Forestry. However, an agreement between the Louisiana Pulp and Paper Association and Louisiana Department of Environmental Quality existed for land application of pulp and paper wastes (LAC, 2012). Discussions with Fort Polk and the Louisiana Department of Agriculture and Forestry regarding a permit occurred as soon as the requirement for a permit was communicated. Most states likely require a similar permit, but specific details will probably vary. Due to the novelty of the paper material, the exact permit that was applicable was not known. This caused a 1 year delay in implementation as initially it was decided that no permit was required, but later the permit was requested. Land application of wastes are often required to adhere to 40 CFR Part 503 (Land Application of Sewage Sludge) at a minimum, and states may have more stringent requirements for one or all regulated contaminants. A primary concern raised during site selection was the creation of an eyesore with paper material covering the soil surface. Due to this concern, our demonstration sites were moved from areas near highly traversed roadways to less frequented areas. 


\section{References}

Alpert, P. and J.L. Maron. 2000. Carbon additions as a countermeasure against biological invasion by plants. Biological Invasions 2:33-40.

AR 200-1. 2007. Environmental Protection and Enhancement. Department of the Army, 13 Dec 2007, Washington, D.C.

Bailey, R.G. 1995, Description of the Ecoregions of the United States. Miscellaneous Publication 1391, USDA Forest Service, Washington, DC.

Blumenthal, D.M., N.R. Jordan, and M.P. Resselle. 2003. Soil carbon addition controls weeds and facilitates prairie restoration. Ecological Applications 13:605-616.

Bremner, J.M. 1996. Nitrogen-total. Pp. 1085-1121 in Sparks, D.L. (ed.) Methods of soil analysis. Part 3. ASA and SSSA, Madison, WI.

Busby, R.R., D.L. Gebhart, and H.A. Torbert. 2006. Effects of an uncomposted municipal waste processing by-product on prairie grass establishment. Agronomy Journal 98, no. 4: 1073-1080.

Busby, R.R., D.L. Gebhart, H.A. Torbert, J.D. Dawson, G.A. Bollero, K.N. Potter, and D.R. Curtin. 2010. Effects of a new waste processing byproduct on soil and vegetation at Fort Campbell, TN. Communications in Soil Science and Plant Analysis 41:250-266.

Busby, R.R., H.A. Torbert, and D.L. Gebhart. 2007. Carbon and nitrogen mineralization of composted and uncomposted municipal solid waste in sandy soils. Soil Biology and Biochemistry 39:1277-1283.

DoD. 2003. Sustainment of Ranges and Operating Areas (OPAREAs). Department of Defense Directive 3200.15, Washington, D.C.

DoD. 2008. DoD Integrated Solid Waste Management Policy. Office of the Under Secretary of Defense, 1 Feb 2008, Washington, D.C.

DoD. 2011a. Army Identifies Net Zero Pilot Installations. News Release 319-11, April 20, 2011, Washington, D.C.

DoD. 2011b. Natural Resources Conservation Program. Department of Defense Instruction 4715.3, 18 Mar 2011, Washington, D.C.

DoD. 2012. Department of Defense Strategic Sustainability Performance Plan, Washington, D.C.

Eschen, R., S.R. Mortimer, C.S. Lawson, A.R. Edwards, A.J. Brook, J.M. Igual, K. Hedlund, and U. Schaffner. 2007. Carbon addition alters vegetation composition on ex-arable fields. Journal of Applied Ecology 44:95-104.

EO. 1999. Invasive Species. Executive Order 13112, Washington, D.C.

EO. 2009. Federal Leadership in Environmental, Energy, and Economic Performance. Executive Order 13514, Washington, D.C. 
Godefroid, S., C. Piazza, G. Rossi, S. Buord, A.-D. Stevens, R. Aguraiuja, C. Cowell, C.W. Weekley, G. Vogg, J.M. Iriondo, I. Johnson, B. Dixon, D. Gordon, S. Magnanon, B. Valentin, K. Bjureke, R. Koopman, M. Vicens, M. Virevaire, and T. Vanderborght. 2011. How successful are plant species reintroductions? Biological Conservation 144:672-682.

Hue, N.V. and C.E. Evans. 1986. Procedures used for soil and plant analysis by the Auburn University Soil Testing Lab. Auburn University, Auburn, AL.

Illinois Department of Transportation (IDOT). 2012. Standard specifications for road and bridge construction.

Kabata-Pendias, A. and H. Pendias. 2001. Trace elements in soils and plants, third edition. CRC Press, Boca Rato, FL.

Kirkpatrick, H.E. and K.C. Lubetkin. 2011. Responses of native and introduced plant species to sucrose addition in Puget lowland prairies. Northwest Science 85:255-268.

Kuchler, A.W. 1966. Potential Natural Vegetation of the Conterminous United States. U.S. Geological Survey, Washington, D.C.

Lockwood, J.L. and S.L. Pimm. 1999. When does restoration succeed? Pp. 363-378 in Weiher, E. and P. Keddy (eds.) Ecological Assembly Rules: Perspectives, Advances, Retreats. Cambridge, UK: Cambridge University Press.

Louisiana Code. 2012. Title 33, Part VII, Subpart 1, Section 3017. Louisiana Pulp and Paper Association Louisiana Department of Environmental Quality Work Group Agreement. Baton Rouge, LA.

McLendon, T. and E.F. Redente. 1992. Effects of nitrogen limitation on species replacement dynamics during early succession on a semiarid sagebrush site. Oecologia 91:312-317.

Mitchell, R.M. and J.D. Bakker. 2011. Carbon addition as a technique for controlling exotic species in Pacific Northwest prairies. Northwest Science 85:247-254.

Morgan, J.P. 1994. Soil impoverishment. Restoration and Management Notes 12:55-56.

Munshower, F.F. 1994. Practical Handbook of Disturbed Land Revegetation. CRC Press, Boca Raton, FL.

Paschke, M.W., T. McLendon, and E.F. Redente. 2000. Nitrogen availability and old-field succession in a shortgrass steppe. Ecosystems 3:144-158.

Perry, L.G., D.M. Blumenthal, T.A. Monaco, M.W. Paschke, and E.F. Redente. 2010. Immobilizing nitrogen to control plant invasion. Oecologia 163:13-24.

Plaster, E.J. 1992. Soil science and management, $3^{\text {rd }}$ Edition. Delmar Publishers, Albany, NY.

Soltanpour, P.N., G.W. Johnson, S.M. Workman, J.B. Jones, Jr., and R.O. Miller. 1996. Inductively coupled plasma emission spectrometry and inductively coupled plasma-mass spectrometry. Pp. 91-139 in Sparks, D.L. (ed.) Methods of soil analysis. Part 3. ASA and SSSA, Madison, WI.

Torbert, H.A., D.L. Gebhart, R.R. Busby, K.N. Potter, and D.R. Curtin. 2007. Non-composted municipal solid waste processing byproduct effect on soil reclamation. Journal of Plant Nutrition 30:755772. 
USC. 1960. United States Code Title 16, Conservation, Chapter 5C, Conservation Programs on Government Lands, Washington, D.C.

Vitousek, P.M. and L.R. Walker. 1987. Colonization, succession and resource availability: ecosystem-level interactions. Pp. 207-222 in Crawley, M.J., P.J. Edwards, and A.J. Gray (eds.). Colonization, succession and stability. Blackwell, Oxford, UK.

Watts, D.B., F.J. Arriaga, H.A. Torbert, D.L. Gebhart, and R.R. Busby. 2012a. Ecosystem biomass, C and $\mathrm{N}$ pools in reclaimed soil five years after municipal solid waste application. Agronomy Journal 104:1305-1311

Watts, D.B., F.J. Arriaga, H.A. Torbert, R.R. Busby, and D.L. Gebhart. 2012b. Noncomposted municipal solid waste byproduct influences soil and plant nutrients 5 years after soil reclamation. Soil Science 177:480-489.

Wedin, D.A. and D. Tilman. 1993. Competition among grasses along a nitrogen gradient: initial conditions and mechanisms of competition. Ecological Monographs 63:199-229.

Wedin, D.A. and D. Tilman. 1996. Influence of nitrogen loading and species composition on the carbon balance of grasslands. Science 274:1720-1723.

Zink, T.A. and M.F. Allen. 1998. The effects of organic amendments on the restoration of a disturbed coastal sage scrub habitat. Restoration Ecology 6:52-55. 


\section{Appendix A: Points of Contact}

\begin{tabular}{|c|c|c|c|}
\hline $\begin{array}{l}\text { POINT OF } \\
\text { CONTACT } \\
\text { Name }\end{array}$ & \begin{tabular}{rr}
\multicolumn{2}{c}{ ORGANIZATION } \\
Name & Address
\end{tabular} & $\begin{array}{l}\text { Phone } \\
\text { Email }\end{array}$ & $\begin{array}{l}\text { Role in } \\
\text { Project }\end{array}$ \\
\hline Ryan Busby & $\begin{array}{l}\text { US Army ERDC-CERL } \\
2902 \text { Newmark Drive } \\
\text { Champaign, IL } 61822\end{array}$ & $\begin{array}{c}\text { (217) 373-7296 (217) 373-7266 } \\
\text { Ryan.R.Busby@usace.army.mil }\end{array}$ & PI \\
\hline Allen Torbert & $\begin{array}{c}\text { USDA-ARS } \\
\text { National Soil Dynamics Lab } \\
411 \text { S. Donahue Drive } \\
\text { Auburn, AL } 36832\end{array}$ & $\begin{array}{c}\text { (334) 844-3979 (334) 887-8597 } \\
\text { Allen.Torbert@ars.usda.gov }\end{array}$ & AI \\
\hline Stephen Prior & $\begin{array}{c}\text { USDA-ARS } \\
\text { National Soil Dynamics Lab } \\
411 \text { S. Donahue Drive } \\
\text { Auburn, AL } 36832\end{array}$ & $\begin{array}{c}\text { (334) 502-2711_(334) 887-8597 } \\
\text { Steve.Prior@usda.gov }\end{array}$ & AI \\
\hline Terrill Turner & $\begin{array}{l}\text { Fort Polk ENRMD } \\
\text { QRP, Bldg. } 3620 \\
\text { Fort Polk, LA } 71459\end{array}$ & $\begin{array}{c}\text { (337) 531-5335 (337) 531-8950 } \\
\text { Terrill.C.Turner.civ@mail.mil }\end{array}$ & Fort Polk POC \\
\hline
\end{tabular}




\section{Appendix B: Equipment Calibration and Data Quality}

\section{Issues}

\section{Calibration of Equipment}

Purchased calibration standards were used to develop response curves for chemical analyses.

\section{Quality Assurance Sampling}

For soil analyses, standards were run as an unknown every 15 samples, and every $15^{\text {th }}$ sample was run as a random duplicate for quality control of equipment.

\section{Sample Documentation}

All paper characterization samples were sealed in bags, labeled by date, and recorded by the performing laboratory in this manner. Soils collected for baseline characterization were numbered using a numbering system associated with a reference grid map, labeled accordingly in bags, and recorded in a log book. All plots were numbered in a log book and on reference maps for use in data collection. Numbers did not indicate treatment to minimize bias. All species composition measurements were recorded in a log book using this numbering convention. All biomass samples were collected and placed into labeled paper bags using the same numbering convention. Weights were recorded on data sheets using the same numbering convention. Biomass subsamples used for plant nutrient analysis were placed into bags using the same numbering convention that was recorded by the performing laboratory. Soil samples were placed into butyrate tubes numbered with the same numbering convention that was recorded by the performing laboratory. Prior to data analyses, all numbers were sorted into appropriate treatments, sites, and blocks for appropriate statistical analyses using the convention listed in the $\log$ book. 


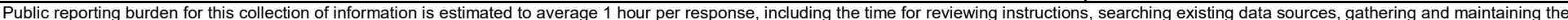

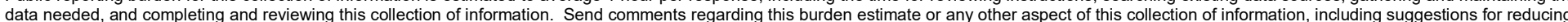

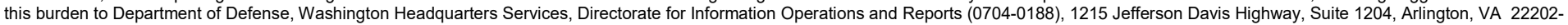

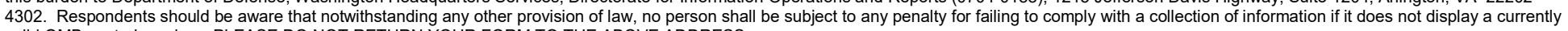
valid OMB control number. PLEASE DO NOT RETURN YOUR FORM TO THE ABOVE ADDRESS.
1. REPORT DATE (DD-MM-YYYY) September 2019 2. REPORT TYPE Final

\section{TITLE AND SUBTITLE}

Pulverized Paper as a Soil Carbon Source for Degraded Training Lands: Final Report

\section{DATES COVERED (From - To)}

5a. CONTRACT NUMBER

5b. GRANT NUMBER

5c. PROGRAM ELEMENT NUMBER

\section{5d. PROJECT NUMBER}

RC-201416

5e. TASK NUMBER

5f. WORK UNIT NUMBER

8. PERFORMING ORGANIZATION REPORT NUMBER

ERDC/CERL SR-19-3

Construction Engineering Research Laboratory

2902 Newmark Drive

Champaign, IL

\section{SPONSORING / MONITORING AGENCY NAME(S) AND ADDRESS(ES)}

Environmental Security Technology

Certification Program

4800 Mark Center Drive

Alexandria, VA 22350

12. DISTRIBUTION / AVAILABILITY STATEMENT

Approved for public release; distribution is unlimited.

\section{SUPPLEMENTARY NOTES}

\section{ABSTRACT}

A demonstration and validation project for the utilization of pulverized classified paper waste as a soil amendment to improve degraded training lands was investigated. Military training lands are often lacking in soil organic matter, which improves water infiltration along with nutrient and moisture retention. When these lands are disturbed, nutrient availability favors weed establishment making restoration difficult. High carbon (C) wastes could help but are unfeasible because of cost and availability. Federal regulations require that classified paper be pulverized to very small fragments, negating recyclability. This material is currently landfilled, so reuse of this waste material is advantageous to training land management and also supports NetZero Waste initiatives.

Based on the results of this project, pulverized paper can be safely applied to degraded training lands to improve establishment of desirable vegetation without any discernable negative consequences. When combining cost savings associated with landfill disposal of the paper with savings from greater land rehabilitation success, an estimated $\$ 300$ per ton of diverted paper is realized. At the recommended application rate, this results in a cost savings of approximately $\$ 4,700$ per acre. At the installation level, this equates to an estimated annual costs savings of $\$ 20,000$ with 70 tons of paper diverted.

\section{SUBJECT TERMS}

Waste paper, Soil amendments, Organic wastes as soil amendments, Military bases, Military training camps, Environmental management

\begin{tabular}{|c|c|c|c|c|c|}
\hline 16. SECURITY CL & IFICATION OF: & & 17. LIMITATION & 18. NUMBER & 19a. NAME OF RESPONSIBLE PERSON \\
\hline $\begin{array}{l}\text { a. REPORT } \\
\text { Unclassified }\end{array}$ & $\begin{array}{l}\text { b. ABSTRACT } \\
\text { Unclassified }\end{array}$ & $\begin{array}{l}\text { c. THIS PAGE } \\
\text { Unclassified }\end{array}$ & SAR & 92 & $\begin{array}{l}\text { 19b. TELEPHONE NUMBER } \\
\text { (include area code) }\end{array}$ \\
\hline
\end{tabular}

